\title{
Blurring Boundaries: From the Danish Welfare State to the European Social Model?
}

Neergaard, Ulla; Nielsen, Ruth

Publication date:

2010

Document version

Publisher's PDF, also known as Version of record

Citation for published version (APA):

Neergaard, U., \& Nielsen, R. (2010). Blurring Boundaries: From the Danish Welfare State to the European Social Model? . (pp. 1-96). Social Science Research Network (SSRN).

http://papers.ssrn.com/sol3/papers.cfm?abstract_id $=1618758$ 


\title{
Blurring Boundaries: From the Danish Welfare State to the European Social Model?
}

\author{
Ulla Neergaard \& Ruth Nielsen ${ }^{1}$
}

\begin{abstract}
This paper builds on the results obtained in the so-called Blurring Boundaries project which was undertaken at the Law Department, Copenhagen Business School, in the period from 2007 to 2009. It looks at the sustainability of the Danish welfare state in an EU law context and on the integration of welfare functions into EU law both from an internal market law and a constitutional law perspective. The main problem areas covered by the Blurring Boundaries project were studied in sub-projects on: 1) Internal market law and welfare services, 2) Fundamental rights and non-discrimination law aspects, and 3) Services of general interest. In the Blurring Boundaries project, three aspects of the European Social Model have been particularly highlighted:
\end{abstract}

- the constitutionalisation of the European Social Model,

- its multi-level legal character, and

- the clash between market access justice at EU level and distributive justice at national level.

\footnotetext{
${ }^{1}$ Professors at the Faculty of Law (research centres CEC and WELMA), University of Copenhagen, and the Law Department, Copenhagen Business School, respectively. The authors wish to thank Associate Professor, Head of Department, Lynn Roseberry, for comments. The paper was finished on 20 May 2010.
} 


\section{Table of Contents}

Blurring Boundaries: ..................................................................................................................

From the Danish Welfare State to the European Social Model? ....................................................... 1

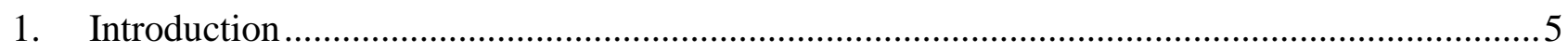

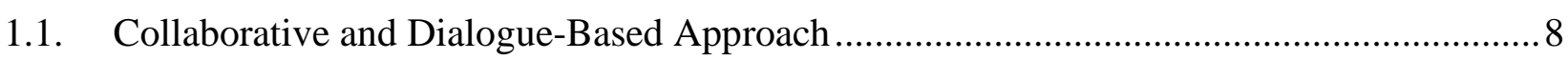

1.2. Evolutionary Perspective............................................................................................. 8

1.3. Comparative with Focus on EU law and the Law of Its Member States as a Multi-level

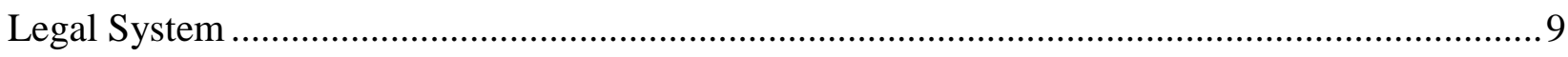

1.4. Legal Dogmatic Analysis of the Mutual Embeddedness of National and EU Welfare Law with a View to the Social and Economic Context of the Law. .........................................................10

2. The Danish Welfare State ………………………………....................................................11

3. The European Social Model and Social Market Economy ......................................................14

4 Balancing Primary EU Law on Free Movement against - National or EU - Welfare Rights ....20

4.1. Narrow or Expansive Interpretation of the Free Movement Provisions in EU Primary Law.21

4.1.1. Welfare Law and the Scope of Competition Law............................................................21

4.1.2. Welfare Law and the Scope of EU Primary Law on Free Movement ...............................23

4.1.3. The ECJ's Expansive Interpretation of Free Movement Law...........................................25

4.2. From a Ban on Discrimination on Grounds of Nationality to a Ban on Restrictions...............27

4.3. Justification of Welfare Restrictions/Discriminations ...........................................................27

4.4. The Interface between Free Movement and Welfare Rights as Fundamental Rights ...............30

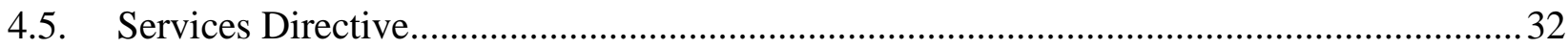

4.6. Preliminary Conclusions ..................................................................................................

5 EU Constraints upon National Welfare Standards through Harmonisation .................................34

5.1. EU Competence in Regard to Welfare Law: the Principle of Conferral ...................................36

5.2. From Unanimity to Qualified Majority Voting in Council .......................................................37

5.3. From Minimum Harmonisation to Full Harmonisation? ...........................................................

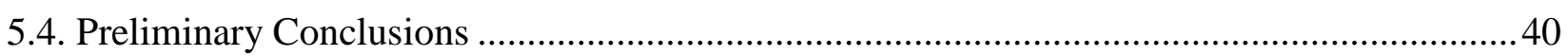

6 Undermining the Solidarity behind the National Welfare States. Market Access Justice at EU

Level and Distributive Justice at National Level ..............................................................................4

6.1 Expansion of Welfare Services and Welfare Rights to Cover EU Migrants and (some) Third Country Nationals as a Matter of EU Law ...............................................................................4

6.2. The Tension between Market Access Justice at EU Level and Distributive Justice at National Level in Regard to Tax-financed Services and Benefits ..............................................................42

6.2.1. Limitation of Member States' Discretion in Regard to Tax Revenue ...............................42 
6.3. The Tension between Market Access Justice and Distributive Justice Related to Minimum Wages: the Laval Case

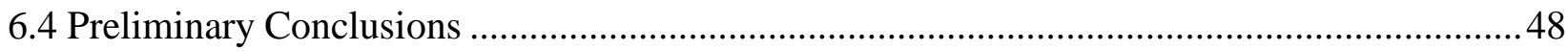

The ECJ tends to interpret EU internal market in a way that sees limitation of market access as

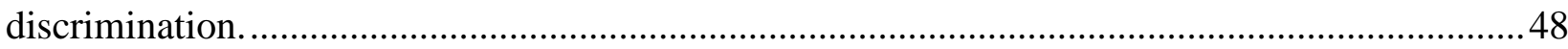

7. Fundamental Social Rights and Non-Discrimination .....................................................49

7.1. The Danish Development from a Non-Constitutional to a Constitutional Approach to Fundamental Social Rights and Non-discrimination................................................................49

7.1.1. Majoritarian, Parliamentary Democracy versus Constitutional Democracy …................49

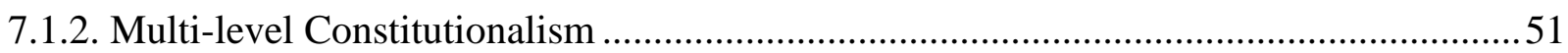

7.1.3. Separation of Power between Legislators and Courts ................................................ 51

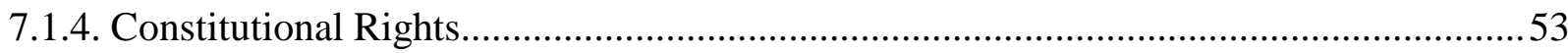

7.2. The EU Development of Protection of Fundamental Social Rights and Non-discrimination ....54

7.2.1. The Distinctions between Civil and Political Rights and Social and Economic Rights ..54

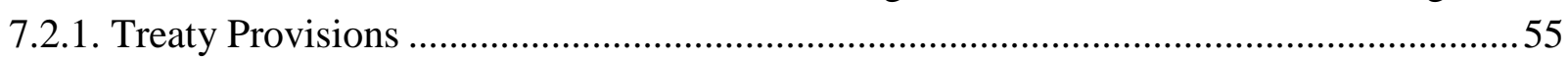

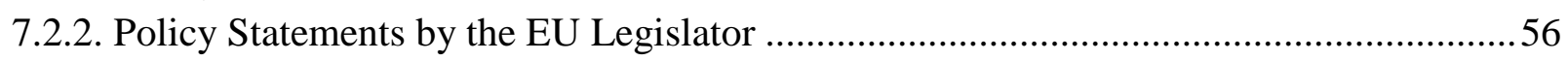

7.2.3. The Case Law of the ECJ on Fundamental Rights .....................................................57

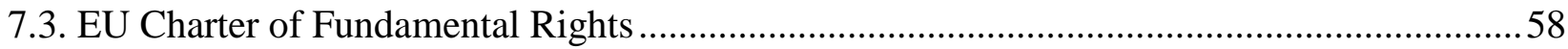

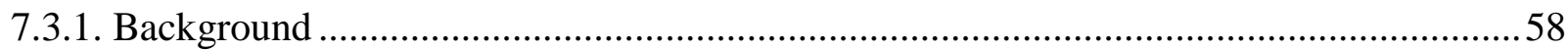

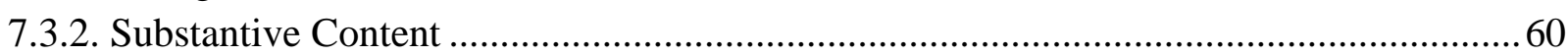

7.3.3. The Same Legal Value as the Treaties. Supremacy and Direct Effect ............................61

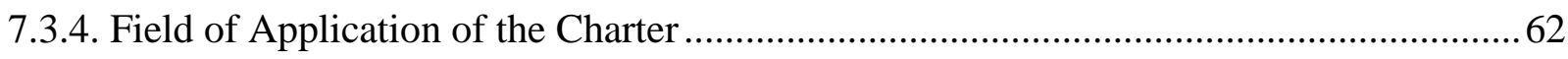

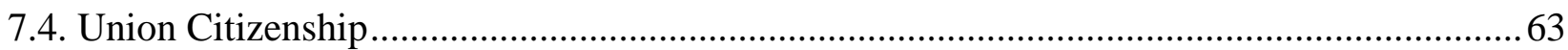

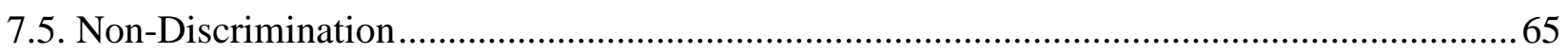

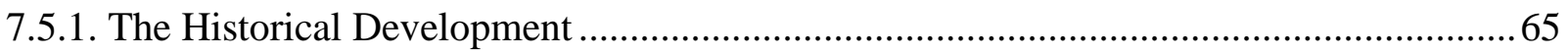

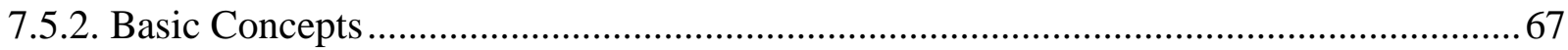

7.5.3. Invoking EU Law against Danish Law before Danish Courts.....................................68

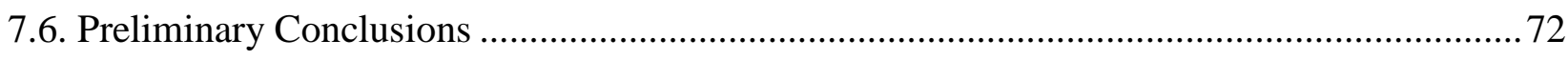

8. Guaranteeing Services of General Economic Interest ........................................................... 72

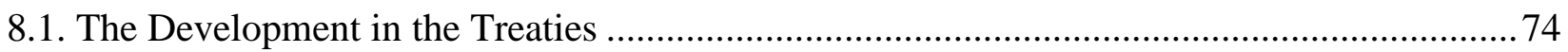

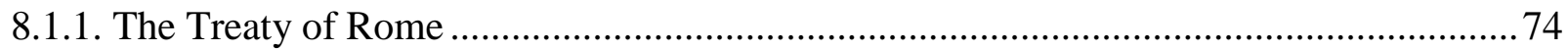

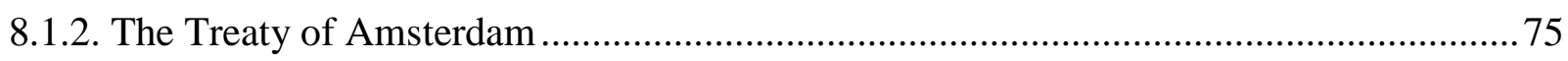


8.1.3. The Treaty of Lisbon..................................................................................................76

8.2 The Development of the Commission's "Soft Law"............................................................ 78

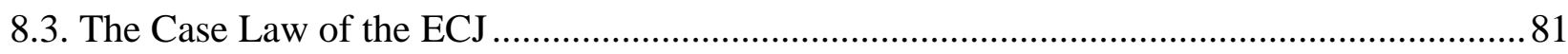

8.3.1. Generally about Article 106(2) FEU (ex Article 86(2) EC) .......................................... 82

8.3.2. Synthesis of What May be Deducted From the Case Law ............................................83

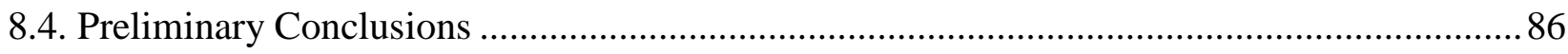

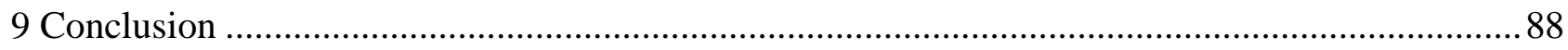

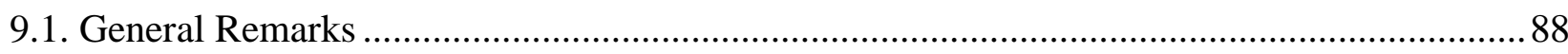

9.2. Research Question 1: Does EU Law Put Constraints upon Danish Law on Core Welfare Services, and If Yes, How, to What Extent and What Is the Trend in the Development?.............89

9.3. Research Question 2: Is EU Law Ensuring the Provision of Core Welfare Services, and If Yes, How, to What Extent and What Is the Trend in the Development?....................................91

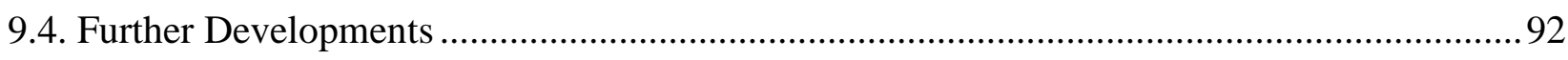

Annex 1. Publications from the Blurring Boundaries project ..............................93 


\section{Introduction}

A welfare state in Europe is typically a nation-state. However, generally there is an increasingly blurred line between such states and EU law (including the legal aspects of the European Social Model) as part of a more comprehensive multi-level legal system where EU law and the national law of its Member States are mutually embedded. Also, the market as such has an increasing influence on the organisation of welfare services. Thus, there is a wave of liberalisation and privatisation, which is changing the traditional way of setting up welfare services. In addition, certain basic values and principles, e.g. non-discrimination, equality, social inclusion, and access to essential services are being pursued in the market place, elevating fundamental rights, values and principles from restrictions on state action to general principles of law binding on both the state and private actors on the market.

This paper explores these issues further. It builds on the results obtained in the so-called Blurring Boundaries project, which was undertaken at the Law Department, Copenhagen Business School, for a three year period from 2007 to 2009 with funding from the Danish Social Science Research Council. ${ }^{2}$ It examined the ongoing Europeanisation of welfare functions. ${ }^{3}$ It has thrown light from a strictly legal perspective on the sustainability of the Danish welfare state in an EU context and on the integration of welfare functions into EU law. ${ }^{4}$ We look at it both from an internal market law and a constitutional law perspective. More concretely, the Blurring Boundaries project aimed to answer the following two main research questions:

- Does EU law put constraints upon Danish law on core welfare services, and if yes, how, to what extent and what is the trend in the development?

- Does EU law ensure the provision of core welfare services, and if yes, how, to what extent and what is the trend in the development?

The main problem areas covered by the Blurring Boundaries project were studied in sub-projects on: 1) Internal market law and welfare services, 2) Fundamental rights and non-discrimination law aspects, and 3) Services of general interest within the meaning of Article 106(2) FEU (ex Article 86(2) EC). ${ }^{5}$ In this paper, we will discuss the (tentative) answers, which the Blurring Boundaries project has contributed with, to these questions. ${ }^{6}$

\footnotetext{
2 The full title of the project is 'Blurring Boundaries: EU Law and the Danish Welfare State'.

${ }^{3}$ For more information about the project, see: http://uk.cbs.dk/content/view/full/5811.

${ }^{4}$ The welfare state has in Denmark been the subject of many other disciplines, such as history, political science, theology, but not much by Danish legal researchers until this project was initiated. It may be of interest that now, at the Faculty of Law at the University of Copenhagen, there is a centre named "Legal Studies in Welfare and EU Market Integration” (WELMA) and another named "European Constitutionalization" (CEC).

${ }^{5}$ Ruth Nielsen has been responsible of the first sub-project, Lynn Roseberry of the second, and Ulla Neergaard of the third.

${ }^{6}$ We are jointly responsible for Sections 1 and 9. However, primarily Ulla Neergaard is responsible of Sections 2, 3, and 8, and primarily Ruth Nielsen of Sections 4-7. The article obviously only includes 'headlines' of the research accomplished and should not
} 
The two questions were formulated back in 2006 in the process of formulating an application for research funding. Although EU law is dynamic whereby four years - which have already passed easily become a long period of time, and although the conception of research questions often changes in the process of working with them, we have decided also in the present paper to keep them in an unchanged form, hereby remaining "faithful" to our original point of departure.

A few further explanatory comments regarding these two questions should be provided from the outset. The first research question may primarily be viewed as concerned with the extent to which a welfare state still has competence to decide how it will organise welfare services, and at what level it will provide welfare services. The second research question may be viewed as changing the focus, as the perspective taken is what may be expected from EU law regarding welfare services. The two questions are rather inter-related by nature, and there is not necessarily a very sharp distinction between them.

In the project, we have taken a broad view of the notion of welfare services often organised at the state level; in fact, as including for example cash benefits, minimum wage systems based on collective agreements, consumer protection, and fundamental rights. As is explained further by Nielsen, the word "welfare" is not used in the Charter of Fundamental Rights of the European Union, and before the coming into force of the Lisbon Treaty, it was only used in the EC Treaty in the context of animal welfare. ${ }^{7}$ In the Lisbon Treaty, the word is used in Article 3 EU on the Union's aims in some - but not all - language versions. ${ }^{8}$ As suggested by Damjanovic \& de Witte, welfare services may be viewed as covering the following two categories: the core welfare services, which are traditionally and still mainly provided by the public sector, and the services provided by public utilities, which in most countries have been owned by the State and organised as monopolies. ${ }^{9}$ However, by now these have largely been liberalised and are pursuant to the two authors to be considered as the "outer ring" of the welfare state, whereas the former kind of welfare services is to be considered as belonging to the "inner ring" of the welfare state. As Damjanovic \& de Witte also emphasise, labour market regulation including institutional arrangements for the social partners and equality policies have an importance in the definition of a welfare state and the European Social Model(s). The perspectives thereof have also been included in the project. The term "core welfare services" has in the Blurring Boundaries project been applied as signifying both

be considered as an exhaustive account of the findings. In this regard, we refer to the three project books mentioned in footnote 15 . In addition, we refer to the publication list in Annex 1.

${ }^{7}$ Ruth Nielsen: The Charter of Fundamental Rights and Migrant Workers’ Welfare Rights, in Ulla Neergaard, Ruth Nielsen \& Lynn Roseberry (eds.): Integrating Welfare Functions into EU Law - From Rome to Lisbon, DJØF Publishing Copenhagen, 2009 , p. 99.

${ }^{8}$ Ibid. Ruth Nielsen further explains at pp. 99-100 that: "In the English version Article 3(1) EU reads: 'The Union's aim is to promote peace, its values and the well-being of its peoples.' In the Danish and Swedish versions of the EU Treaty, the Danish and Swedish words for welfare (velfærd, välfärd) are used where the English version uses 'well-being'. The German version uses the word 'Wohlergehen' and the French version 'bien-être'. In the Commission's communication from July 2008 on a renewed social agenda [footnote omitted], there is a similar difference in different language versions.”

${ }^{9}$ Dragana Damjanovic \& Bruno de Witte: Welfare Integration through EU Law: The Overall Picture in the Light of the Lisbon Treaty, in: Ulla Neergaard, Ruth Nielsen \& Lynn Roseberry (eds.): Ulla Neergaard, Ruth Nielsen \& Lynn Roseberry (eds.): Integrating Welfare Functions into EU Law - From Rome to Lisbon, Djøf Publishing Copenhagen, 2009, p. 53 et seq. Also see the alternative categorisation by Ulla Neergaard taken with the point of departure in the terminology of the Treaty: Services of General Economic Interest: The Nature of the Beast, in Markus Krajewski, Ulla Neergaard \& Johan van de Gronden (eds.): The Changing Legal Framework for Services of General Interest in Europe. Between Competition and Solidarity, T. M. C. Asser Press, 2009, pp. 17-50. 
the inner and the outer rings of the welfare state, thus hereby in a different meaning than the one launched by Damjanovic \& de Witte.

The law of relevance to the Blurring Boundaries project - both at EU level and at national level - is based on a number of different kinds of legal sources. Possible (binding) EU law constraints can come from primary law, notably the Treaty provisions (including the Charter of Fundamental Rights of the European Union) on free movement and fundamental rights and ECJ case law on these issues, and from secondary law, primarily in the form of harmonising directives, e.g. the Services Directive. In the Blurring Boundaries project most of the contributions focus on analysing primary EU law (Treaty provisions and general principles of EU law), case law from the ECJ and selected elements of national law. A few directives, in particular the Services directive, have also been studied in more detail. ${ }^{10}$ Also, cutting across various legal disciplines has been necessary (e.g. EU constitutional law, human rights law, competition law, labour law, social security law, etc.); therefore, for instance, a strict social law perspective has not been taken.

The primary method used in the Blurring Boundaries project is in general a legal, dogmatic analysis, i.e. the traditional legal method is applied. ${ }^{11}$ It is concerned with a textual analysis of authoritative sources of law, e.g. legislative acts, judgments, etc. There are some characteristic differences between the pattern of sources of law in Danish law and in EU law. In the Blurring Boundaries project the focus is on EU law. As EU law has certain specific characteristics compared to national law, this has been given consideration. ${ }^{12}$ Under all circumstances, there is an emphasis on the interpretation of legal texts and case law. In other words, it is written by lawyers and in so far as the law is built with words, legal science will begin with them, which is why legal science is largely about hermeneutics. ${ }^{13}$ At the same time, a more critical approach is applied, as the analyses are not intended solely to be of a descriptive character. As has been pointed out in legal theory regarding EU law:

\begin{abstract}
"Formal reasoning may be necessary (for example, to secure certainty and equality under the law), but it is no longer sufficient. Because formal arguments no longer provide all the legal answers, a justification based on formal arguments is, in many cases, no longer legitimate justification. Judicial neutrality, with reference to an ideal "robotcourt”, associated with syllogistic reasoning in the application and interpretation of law, does not correspond to the present complexity of the judicial process and the exercise of discretion it entails. This is by now a non-contentious assertion. The exercise of judicial discretion requires a "second-order justification" involving "justifying choices; choices between the rival rulings which are possible". ${ }^{14}$
\end{abstract}

The Blurring Boundaries project is mono-disciplinary in the sense that it is a legal dogmatic analysis and not a multi-disciplinary analysis. Law, the EU and the welfare state are objects of interest not only to legal science but also to other social sciences, e.g. political science, economy

\footnotetext{
${ }^{10}$ See Ulla Neergaard, Ruth Nielsen \& Lynn Roseberry (eds.): The Services Directive - Consequences for the Welfare State and the European Social Model", Copenhagen, 2008.

11 See further Ruth Nielsen \& Christina D. Tvarnø: Retskilder \& Retsteorier, Copenhagen 2005, part II; or Alf Ross: Ret og Retfærdighed, Copenhagen, 1953.

12 See e.g. Hjalte Rasmussen: EU-ret i kontekst, Thomson, 2003, pp. 155 and 158.

13 See e.g. Julio Baquero Cruz: Between Competition and Free Movement. The Economic Constitutional Law of the European Community, Hart Publishing, 2002, p. 4.

14 Miguel Maduro: We, the court. The European Court of Justice \& the European Economic Constitution, Hart Publishing, 1998, p. 20.
} 
and sociology. We have focused on the analysis of legal texts in order to find out what the answers to our research questions are on the basis of the legal material interpreted in accordance with a professional, legal standard.

In addition to what has already been stated above, the approach(es) applied in the Blurring Boundaries project can at the overall level be described as characterised by at least the following dimensions: a) being collaborative and dialogue-based; b) taking an evolutionary perspective; c) being comparative with focus on looking at EU law and its interaction with the law of its Member States as a multi-level legal system; and d) as providing a legal dogmatic analysis of the mutual embeddedness of national and EU welfare law with a view to the social and economic context of the law. These four dimensions will be further explained in what now follows.

\subsection{Collaborative and Dialogue-Based Approach}

The above research questions were studied more closely by the members of the Blurring Boundaries research group (Ulla Neergaard, Lynn Roseberry, Ruth Nielsen) and a PhD student (Grith Ølykke) in collaboration and dialogue with leading legal scholars from a number of European countries, who were invited as international speakers at three conferences arranged as part of the Blurring Boundaries project and as guest authors of anthologies written on the basis of the papers given at those conferences. Three conferences were held on the following themes:

2007 The Services Directive and its impact on the Welfare State and the European Social Model 2008 The Lisbon Treaty - a Step towards Integrating Welfare Functions into EU Law?

2009 The Role of the Courts in Developing a European Social Model - Theoretical and Methodological Perspectives

On the basis of the papers presented at each of the three conferences, three books edited by Ulla Neergaard, Ruth Nielsen and Lynn Roseberry were published. ${ }^{15}$ The three books from the Blurring Boundaries conferences contain 28 articles altogether on different aspects of the problems studied in the Blurring Boundaries project written by 22 different authors. The PhD student has written a PhD thesis. ${ }^{16}$

\subsection{Evolutionary Perspective}

The contributors to the Blurring Boundaries conferences and books have generally looked at the various aspects of the interface between EU law and national and EU welfare law in an evolutionary perspective, tracing the development from the Treaty of Rome 1957 to the period shortly before the coming into force of the Lisbon Treaty 1 December 2009. ${ }^{17}$

\footnotetext{
${ }^{15}$ Ulla Neergaard, Ruth Nielsen \& Lynn Roseberry (eds.): The Services Directive - Consequences for the Welfare State and the European Social Model, DJØF Publishing, 2008, http://www.djoef-forlag.dk/vare/8757418063, Ulla Neergaard, Ruth Nielsen \& Lynn Roseberry (eds.): Integrating Welfare Functions into EU Law - From Rome to Lisbon, DJØF Publishing, 2009, see http://www.djoef-forlag.dk/vare/8757418985, Ulla Neergaard, Ruth Nielsen \& Lynn Roseberry (eds.): The Role of Courts in Developing a European Social Model - Theoretical and Methodological Perspectives, DJØF Publishing, 2010, see http://www.djoefforlag.dk/vare/8757421722, see for details on the publications from the Blurring Boundaries project Annex 1.

${ }^{16}$ Grith Ølykke: Low Tenders - With an Emphasis on Public Tenderers, DJØF Publishing, Copenhagen 2010.

${ }^{17}$ See for example Dragana Damjanovic \& Bruno de Witte: Welfare Integration through EU Law: The Overall Picture in the Light of the Lisbon Treaty; and Ulla Neergaard: Services of General (Economic) Interest: What Aims and Values Count? Both in Ulla
} 
1.3. Comparative with Focus on EU law and the Law of Its Member States as a Multilevel Legal System

There are as mentioned 28 articles in the three books from the three Blurring Boundaries conferences written by 22 different authors. They come from 14 different national backgrounds: the four Nordic countries (Denmark, Finland, Norway and Sweden), Germany, England, Holland, Belgium, Austria, Spain, Italy and Greece, but there are none from Ireland, France, Portugal and Luxembourg. Two of the authors have a background in Eastern Europe ${ }^{18}$ and one in the United States. $^{19}$

The focus in the contributions to the Blurring Boundaries project is on EU law and its interaction with the national law of its Member States. There is no in-depth analysis of any one particular country. The Blurring Boundaries project is a Danish project in the sense that it has been funded by the Danish (state's) Social Science Research Council and was organised/carried out by a research group (Ulla Neergaard, Ruth Nielsen and Lynn Roseberry) and a PhD.-student (Grith Ølykke), who are all employed with a Danish University. ${ }^{20}$ The outcome of the project has, however, not so far been particularly focused on Danish law and Denmark or on what has happened to Danish law since Denmark's membership (as of 1 January 1973) of the EU. In the three first books from the Blurring Boundaries project Danish law is only used as one among other examples of national responses to EU law. As appears from the composition of the author group, the Northern part of Europe represented more strongly than the Mediterranean countries and Eastern Europe, but the Danish participants are not particularly numerous. The PhD student and two of the members of the Blurring Boundaries research group are Danish citizens. ${ }^{21}$ They are the only Danes who have participated in the project. The research group has chosen not to invite other Danes to speak or write in the project and has given preference to participants with a background in other EU/EEA-countries in order to include insights from other legal traditions in Europe. There are no "länderberichte" or systematic comparisons of different national legal systems. Some of the contributions include comparisons with public international law. ${ }^{22}$ In this paper we do, however, focus on the consequences for the Danish welfare state of the development that has taken place in EU law and its interaction with the law of its Member States.

The term 'blurring boundaries' in the project title refers both to the increasingly blurred line between public and private law in regard to welfare services and to the blurring boundaries between EU law and national law on this subject. In the first years of its existence EU law was generally perceived as rather superficial and fragmentary with many gaps and inconsistencies. At that time, EU law and national law were usually studied as two separate sets of law. Now, EU law is ripening,

Neergaard, Ruth Nielsen \& Lynn Roseberry (eds.): Integrating Welfare Functions into EU Law - From Rome to Lisbon, DJØF Publishing, 2009.

${ }^{18}$ One (Andrzej Swiatkowski) is a professor in Krakow (Poland), and one (Antonina Bakardjieva Engelbrekt), who is now a professor in Sweden, comes from Bulgaria and received her primary legal education in that country.

${ }^{19}$ Lynn Roseberry, who now works as associate professor in Denmark, comes from the US where she received her primary legal education.

${ }^{20}$ Copenhagen Business School (CBS). Ulla Neergaard is since 1 October 2009 professor at the Faculty of Law at the University of Copenhagen.

${ }^{21}$ Ulla Neergaard \& Ruth Nielsen.

${ }^{22}$ See in particular Mia Rönnmar: Labour Law in the Courts. The Role of European Case Law on Fundamental Trade Union Rights in an Evolving EU Industrial Relations System, and Lynn Roseberry: International Human Rights Treaties and Fundamental Rights in the Case Law of the European Court of Justice: Pointing towards a European Social Model? 
and the mutual embeddedness of EU law and the national law of its Member States is becoming more intense. Nearly all the contributions to the Blurring Boundaries project deal, in one way or another, with this mutual embeddedness of EU law and national law in relation to welfare services.

\subsection{Legal Dogmatic Analysis of the Mutual Embeddedness of National and EU Welfare Law with a View to the Social and Economic Context of the Law.}

Most of the articles in the Blurring Boundaries project contain dogmatic legal analyses of the mutual embeddedness of national and EU welfare law. Many look at law in its social and economic context. Dagmar Schiek, for example, underlines that the "European Social Model” encompasses socio-economic elements. It comprises the interrelation between markets, social spaces, and civil society, going beyond labour law, employment regulation, social security, and welfare, although all these are important components of the European Social Model. ${ }^{23}$

There are marked differences between the methods and practices used for answering research questions in legal dogmatic research and the methods used in other social or humanistic sciences studying law as an object. ${ }^{24} \mathrm{~A}$ reason for this is that it is necessary to use different methods to answer different research questions. In dogmatic studies of law the questions relate to what is valid law, and the material examined in order to arrive at an answer is a normative material (the sources of law), which is read and interpreted in accordance with the expert legal culture. The legal method(s) applied in dogmatic legal research have common traits with the scholastic methods developed in early natural law theory where a statement was regarded as true when it could be traced back to an authoritative source. ${ }^{25}$

On this background, the focus will now move to the presentation itself of some of the results on the basis of the contributions delivered within the Blurring Boundaries project, but also on the wider insights we have gained throughout the process. We will structure the discussion around the following headings: Section 2) The Danish Welfare State; Section 3) The European Social Model and Social Market Economy; Section 4) Balancing Primary EU Law on Free Movement against National or EU Law - Welfare Rights; Section 5) EU Constraints Upon National Welfare Standards through Harmonisation; Section 6) Undermining the Solidarity behind the National Welfare States. Market Access Justice at EU level and distributive justice at national level; Section 7) Fundamental Social Rights and Non-Discrimination; Section 8) Guaranteeing Services of General Economic Interest; and Section 9) Conclusions. Sections 2 and 3 mainly explain the two main concepts (the welfare state and the European Social Model) used in the title of this paper and serve the main purpose of explaining the framework in which the research questions of the Blurring Boundaries project operate. Sections 4-8 are meant to dig in another direction, as more concrete areas of problems are addressed here in relationship to the two research questions.

\footnotetext{
${ }^{23}$ Cf. Dagmar Schiek: The European Social Model and the Services Directive, in Ulla Neergaard, Ruth Nielsen \& Lynn Roseberry (eds.): The Services Directive - Consequences for the Welfare State and the European Social Model", DJØF Publishing, 2008.

${ }^{24}$ See for example the analysis of the debate on an EU Constitution from a rhetorical perspective in Sine Nørholm Just: The Constitution of Meaning - A Meaningful Constitution?, Copenhagen 2005, where the author inter alia uses newspaper articles as source material, and the analysis of Article 234 EC references from a political science perspective in Marlene Wind: The Nordics, the EU and the Reluctance Towards Supranational Judicial Review, Journal of Common Market Studies 2009, where the author examines what judges do (not by reading their judgments but) by sending them questionnaires.

${ }^{25}$ See Martijn Hesselink: A European Legal Method? On European Private Law and Scientific Method, European Law Journal, 2009, p. 20.
} 


\title{
2. The Danish Welfare State
}

In this Section, the purpose is to sketch out the main characteristics of the Danish welfare state in its Nordic context. In order to understand the influence of EU law as spelled out in the research questions (especially the first one) outlined above in Section 1, a logic first step is to understand the organisation of the Danish welfare state, at least as for its main principles.

Providers of welfare are in principle: the family, the civil society, the market, and the state. ${ }^{26}$ Kuhnle \& Alestalo explain that: “The market may provide welfare in two ways, either in the form of responding to demand for individual or collective insurance or services or in the form of firms offering welfare to their own employees. ... '[T]he state'... embraces both central and local government. By "civil society" we refer to the complex of social organisations and associations 'that are not strictly production-related nor governmental or familial in character'...” In Denmark the provision of welfare services through the welfare state has been a key element for a number of years, and there has been considerable political consensus on the desirability of preserving the welfare state. ${ }^{27}$ This is not stated in the Constitution itself, which generally may be considered as rather old-fashioned or "immature", and not very "rich" in its listing of rights. Denmark has traditionally not protected fundamental social rights or the principle of non-discrimination in the text of the Constitution. If compared it with e.g. the constitutional elements of the Lisbon Treaty, the distance between the two sources of law becomes almost enormous.

The present liberal-conservative Danish Government and the majority of the remaining parties of the Parliament have recently expressed a certain interest in this issue in the Political Agreement on Danish EU Policy in a Globalised World of 21 February 2008. Here, it is among others stated:

\begin{abstract}
"We must use the EU to promote an economically and socially sustainable development. The EU must be used to secure the framework for the European welfare states. Through this framework, the EU must strengthen the opportunities for us to preserve the Danish welfare model. The organisation of the welfare state will remain a national responsibility. The parties to the Agreement place emphasis on maintaining the basis for financing the welfare state, including by fighting tax evasion.” 28
\end{abstract}

In other words, this indicates that it is central - however, not necessarily realistic - for a Member State like Denmark to preserve its welfare model and that it is considered that the organisation of the welfare society is still a national task. ${ }^{29}$ The quotation also reflects how a process of iconisation of the welfare state has taken place. ${ }^{30}$

\footnotetext{
${ }^{26}$ Stein Kuhnle \& Matti Alestalo: Introduction, in Stein Kuhnle (ed.): Survival of the European Welfare State, Routledge, 2000 , p. 6.

${ }^{27}$ Niels Finn Christiansen: The Nordic Model of Welfare, Copenhagen 2006. Denmark is often considered to be the second country in the world - following Germany - to enact modern welfare legislation, which happened in 1891; see Tim Knudsen: Tilblivelsen af den universalistiske velfærdsstat, in Tim Knudsen (ed.): Den nordiske protestantisme og velfærdsstaten, Aarhus Universitetsforlag, 2000, p. 20. The 1891 initiative concerned a law on pensions, which pursuant to Knudsen deviated from the system established by Bismarck, as it was constructed on a principle of universality and tax financing. Pursuant to the author, Denmark hereby became the first country in the world to introduce a general right for every citizen over the age of 60 to receive a pension on the cause of age, however, on the condition of a need to be estimated to exist.

${ }^{28}$ See: http://www.stm.dk/Index/dokumenter.asp?o=173\&n=1\&d=2994\&s=2.

${ }^{29}$ It should be emphasised that there is no definition of what the parties which have entered the Europe Political Agreement mean by their reference to the Danish welfare model.

${ }^{30}$ See in this regard, e.g. Kjell Åke Modéer: Adjustment or Reluctance? Scandinavian Exceptionalism in Legal Cultures, in Hanne Petersen, Anne Lise Kjær, Helle Krunke \& Mikael Rask Madsen (eds.): Paradoxes of European Legal Integration, Ashgate, 2008, p. 290.
} 
What, more exactly, constitutes a welfare state in principle is not easily defined. ${ }^{31}$ Traditionally, the following traits have been considered essential characteristics of the classic Nordic welfare state: publicly owned infrastructure; tax financed welfare services in the form of state services; high quality and high level state services and an interplay between state services and the labour market resulting in flexicurity; i.e. a high degree of flexibility in employment combined with a fairly high degree of income security and a guaranteed minimum living standard. At the general level it builds on a principle of people living in the country in which they were born. ${ }^{32}$ In addition, it is largely based on solidarity mechanisms. ${ }^{33}$ Also, in many of its elements it is universal in character so that everyone is secured and where individual rights are combined with collective financing through general taxation. ${ }^{34}$ In contrast, many other European models have as their guiding principle a connection between individual contribution and the size of the benefits to be received. ${ }^{35}$ From the beginning of the $20^{\text {th }}$ century, the Nordic states extended the public sphere, but the provision of welfare services remained based on a fairly sharp distinction between public and private.

As Schiek points out, the Scandinavian countries have been defined by Esping-Andersen in his seminal work as representing a social-democratic model. ${ }^{36}$ She explains that:

\begin{abstract}
"The social democratic (or Nordic) model is based on the universal coverage of risks by state provided welfare. Of course, Esping-Andersen may have overlooked the strong roots of unemployment insurance in the trade union movement here, [footnote omitted] but this does not disturb him, as pension and health care systems are much larger and economically more relevant than unemployment. Another characteristic of the social democratic model is said to be market closure. Private welfare solutions are foreclosed ball-encompassing public solutions, and institutional provision of welfare. For the same reason, the Nordic model provides a high density of institutional preproduction services, in particular in the childcare sector [footnote omitted] but also as regards care for the elderly and health care. The third characteristic of the social-democratic model is said to be 'productivism', [footnote omitted] accompanied by public responsibility of a sufficient number of quality jobs for all, and resulting in a proactive approach to the unemployment problem: while employers are free to choose dismissal as an answer to any economic problem, the affected employees find high levels of unemployment benefits and an effective relocation service working for them instead of suffering unemployment bureaucracy with no effects. All these features result in high levels of employment, and in particular in high levels of female employment, including mothers. As regards industrial relations, the 'social democratic' model relies on labour market regulation by collective agreements based on a high degree of unionisation in industry-wide unions.” ${ }^{37}$
\end{abstract}

\footnotetext{
${ }^{31}$ See e.g. Nicholas Barr: The Economics of the Welfare State, Oxford University Press, 2003 (4 ${ }^{\text {th }}$ ed.), p. 6.

32 Jørn Henrik Petersen: Kan den danske velfærdsmodel videreføres?, in: Jens Holger Schjørring \& Jens Torkild Bak (eds.): Velfærdsstat og kirke, Anis 2005, p. 13.

${ }^{33}$ See further e.g. Ulla Neergaard: In Search of the Role of 'Solidarity' in Primary Law and the Case Law of the European Court of Justice, in Ulla Neergaard, Ruth Nielsen and Lynn Roseberry (eds.): The Role of the Courts in Developing a European Social Model. Theoretical and Methodological Perspectives, Djøf Publishing Copenhagen, 2010, pp. 99-140.

34 Jørn Henrik Petersen: Kan den danske velfærdsmodel videreføres?, i: Jens Holger Schjørring \& Jens Torkild Bak (eds.): Velfærdsstat og kirke, Anis 2005, p. 14.

${ }^{35}$ See e.g. Jørn Henrik Petersen: Kan den danske velfærdsmodel videreføres?, in: Jens Holger Schjørring \& Jens Torkild Bak (eds.): Velfærdsstat og kirke, Anis 2005, p. 14, and Uffe Østergaard: Lutheranismen og den universelle velfærdsstat, in: Jens Holger Schjørring \& Jens Torkild Bak (eds.): Velfærdsstat og kirke, Anis 2005, pp. 148-153.

${ }^{36}$ Dagmar Schiek: The European Social Model and the Services Directive, in Ulla Neergaard, Ruth Nielsen \& Lynn M. Roseberry (eds.): The Services Directive: Consequences for the Welfare State and the European Social Model, DJØF Publishing, 2008 , p. 27. Also see the mentioned work itself: Gøsta Esping-Andersen: The Three Worlds of Welfare Capitalism, Princeton University Press, 1990.

${ }^{37}$ Ibid. pp. 28-29. Also see e.g. Pål Eitrheim \& Stein Kuhnle: Nordic welfare states in the 1990s. Institutional stability, signs of divergence, Routledge, 2000, pp. 39-57.
} 
In the alternative, explanations as to the different constructions of welfare states in Europe have been made with the point of departure taken in different religious roots. Thus, it may be taken into consideration as a significant factor of influence that all the Nordic countries have in common that they are based on Protestantism where a Lutheran state church traditionally has dominated. ${ }^{38}$ According to Manow, in these countries not much stood in the way of the government taking over responsibility for the welfare of its citizens. ${ }^{39}$ Other factors of significance could be the high degree of homogeneity of the population, which may ease solidarity mechanisms. Also, historically certain fortunate economic factors have been of importance in facilitating the development.

Despite the many common traits among the Nordic countries, differences also prevail. ${ }^{40}$ In fact, these seem to increase more and more over the years. ${ }^{41}$ Regarding the Danish welfare state, it was in 2005 formulated by the "Welfare Commission" that the future society of welfare is a society which ensures security by investing in its citizens and which takes care of those who are in need of help; where everyone participates actively in community life, takes responsibility and if possible supports themselves; which actively works against poverty and polarisation between different population groups; and which contributes to Denmark continuing to be among the richest countries in the world and to the country having order in its economy. ${ }^{42}$

Under all circumstances, it is a recurring question in the Blurring Boundaries project undertaken whether, among others, liberalisation and privatisation, which is generally - but not only promoted at the economic and social level through the development of the Internal Market in the EU, may put pressures on welfare states and create tensions between EU and Member States. This probably being so to a larger degree in the case of the Nordic versions of a welfare state rather than in the case of other constructions. ${ }^{43}$

\footnotetext{
${ }^{38}$ See especially Philip Manow: 'The Good, the Bad, and the Ugly' - Esping-Andersen’s Regime Typology and the Religous Roots of the Western Welfare State, MPIfG Working Paper 04/3, September 2004, Max-Planck-Institut für Gesellschaftsforschung. Also see e.g.: Tim Knudsen (ed.): Den nordiske protestantisme og velfærdsstaten, Aarhus Universitetsforlag, 2000; Tim Knudsen: De nordiske statskirker og velfærdsstaterne, in Klaus Petersen (ed.): 13 historier om den danske velfærdsstat, Syddansk Universitetsforlag, 2003, pp. 37-46; Brian Patrick McGuire: Da himmelen kom nærmere, Alfa, 2008, pp. 234-235; Jens Holger Schjørring \& Jens Torkild Bak (eds.): Velfærdsstat og kirke, Anis 2005; Steinar Stjernø, Solidarity in Europe. The History of an Idea, Cambridge University Press, 2004, Chapter 3; Uffe Østergaard: Lutheranismen, danskheden og velfærdsstaten, in Klaus Petersen (ed.): 13 historier om den danske velfærdsstat, Syddansk Universitetsforlag, 2003, pp. 27-36; and Uffe Østergaard: Martin Luther og dansk politisk kultur. Nationalkirke, luthersk reformation og dansk nationalisme, Kritik 195, 2010 (forthcoming). It should be emphasised that in Sweden, there is no longer a state church.

${ }^{39}$ Ibid. p. 7.

40 See e.g. Niels Finn Christiansen, Klaus Petersen, Nils Edling \& Per Haave: The Nordic Model of Welfare. A Historical Reappraisal, Museum Tusculanum Press, 2006, where the "Nordic model of welfare” is understood as a model with five exceptions (Denmark, Sweden, Norway, Finland and Iceland).

${ }^{41}$ See e.g. Kjell Åke Modéer: Adjustment or Reluctance? Scandinavian Exceptionalism in Legal Cultures, in Hanne Petersen, Anne Lise Kjær, Helle Krunke \& Mikael Rask Madsen (eds.): Paradoxes of European Legal Integration, Ashgate, 2008, p. 290, who states: "The traditional myth of the homogenous Scandinavian icon has cracked". For details, also see p. 290 et seq; or e.g. Mark Kleinman: A European Welfare State? European Union Social Policy in Context, Palgrave, 2002, p. 44 et seq. For an account of the Danish development, see e.g. Kirsten Ketscher: Socialret. Principper. Rettigheder. Værdier, Thomson, 2008, Chapter 15.

${ }^{42}$ Velfærdskommissionen: Fremtidens velfærd - vores valg, December 2005, p. 2. Also see Jørgen Goul Andersen: Welfare crisis and beyond. Danish welfare policies in the 1980s and 1990s, in Stein Kuhnle (ed.): Survival of the European Welfare State, Routledge, 2000, pp. 69-87.

${ }^{43}$ See e.g. Kirsten Ketscher: Socialret. Principper. Rettigheder. Værdier, Thomson, 2008, p. 43, who argues that the biggest threat to the rationale behind the taxpayer-funded welfare system seems likely to come from the legal logic that the European Union is based, as free movement across borders of goods, labour and capital is at a crucial confrontation with the national format. Also see pp. 275 et seq. In the same direction, see e.g. Gráinne de Búrca: Towards European Welfare, in Gráinne de Búrca: EU Law and the Welfare State. In Search of Solidarity, Oxford University Press, p. 4.
} 


\section{The European Social Model and Social Market Economy}

If we, in contrast to the Danish welfare state, now take a look at the level of the EU, it is of significance that welfare for long largely was regarded as the concern of, and within the competence of the Member States, not truly of the EU. As already slightly indicated in the previous section, this point of departure has to some degree changed, and continues to change further. In that context, it has now become a common theme to talk about a European Social Model as a point of reference. This concept will be further explained in what follows together with the related concept Social Market Economy. This is of importance to the research questions (especially the second one) stated above in Section 1.

To begin with the very beginning, when the European Economic Community was founded in 1958, the then Article 2 EEC enumerated a number of aims, which should be achieved by establishing a common market and gradually approximating the Member States' economic policies. Since the Treaty of Maastricht, which came into force 1 November 1993, and even more since the Amsterdam Treaty, which entered into force 1 May 1997, the economic aims of the EU indicated in the Treaty texts have been complemented by more political aims including a number of welfarerelated policies. The Treaty of Amsterdam introduced new social norms, in particular: A broad competence for the EU to create non-discrimination law (Article 13 EC, now Article 19 FEU) also on other grounds than nationality and gender such as ethnicity, religion, age, disability and sexual orientation and a fundamental acknowledgement of services of general interest (then Article 16 EC, now Article 14 FEU). In relation to this development, it may be mentioned that in the Statement from the Paris Summit in 1972, it is stated that:

"The Heads of State or Heads of Government emphasized that they attached as much importance to vigorous action in the social fields as to the achievement of the Economic and Monetary Union. They thought it essential to ensure the increasing involvement of labour and management in the economic and social decisions of the Community.” 44

The ECJ has already in the Defrenne-II judgment from 1976 ruled that the equal pay provision in the then EC Treaty (now Article 157 FEU) forms part of the social objectives of the EU, which is not merely an economic union, but is at the same time intended, by common action, to ensure social progress and seek the constant improvement of the living and working conditions of their peoples. ${ }^{45}$ The ECJ stated in para. 12 (emphasis added):

'...this double aim, which is at once economic and social, shows that the principle of equal pay forms part of the foundations of the community...'

In its Cassis de Dijon judgment on free movement, which is from the same historical period as the Defrenne-II-ruling, see below in Section 4, the ECJ expanded the issues of overriding public interests on which the Member States can rely when justifying restrictions to the fundamental freedoms so as to allow Member States to uphold a number of rules on their welfare states even

\footnotetext{
${ }^{44}$ See http://www.ena.lu/statement_paris_summit_19_21_october_1972-020002284.html.

${ }^{45}$ Case 43/75 [1976] ECR 455.
} 
when they restrict the free movement in the EU. However, in the area of competition law, the economic aims have seemed to continue to dominate. ${ }^{46}$

Thus, it is of importance to stress that the development has not necessarily been identical in all areas of EU law, as some areas have been steps ahead of others. Also, it is not necessarily possible to draw a straight line of development, as the first many steps of development have occurred in a somehow fragmented manner. Furthermore, at times crucial changes have occurred e.g. through Treaty amendments, and at other times through important judgments of the ECJ. In other words, it may be difficult to identify what exactly was the step(s) which changed all, also because - as many other historical developments - at times this is only possible to establish much later when a pattern of development as such is detectable. In addition, the priorities taken in this regard may vary from EU institution to EU institution.

Several of the papers from the Blurring Boundaries project present re-statements and re-readings of the acquis communautaire in light of the evolving European Social Model. ${ }^{47}$ The concept of course has also been dealt with in academic writing outside the project. On the basis thereof, it may among others be mentioned that the concept as such of European Social Model is several years old by now, as it was applied for the first time by the Commission in $1994 .{ }^{48}$ Also, the most important step in this regard may be viewed as having been taken with the formulation of the Lisbon strategy in 2000, which may be viewed as the result of a compromise between the neo-liberal and the more socially-oriented governments of Member States. ${ }^{49}$ Some authors have raised doubt as to whether the latter term really can be considered to exist. ${ }^{50}$ One author has characterised the term as: “...a rather diffuse amalgam of ideas and principles constructed principally by the Commission to justify social policy interventions on the part of the EU". ${ }^{51}$ Others have characterised it as a concept that has “...an ambiguous and polysemic nature”. ${ }^{52}$ Some emphasise the importance of a shared set of values that have given rise to the welfare state in the Member States, which are distinct from those in, for instance, the US. ${ }^{53}$ Others again have pointed out that one cannot speak of a single "European Social Model”. For instance, Kleinman points out that:

"Rather, there is a range of different European social models in existence. As there is no single European model, it logically follows that the idea that European Social Policy is about 'defending' a European Social Model against,

\footnotetext{
${ }^{46}$ Case 120/78 Rewe-Zentrale AG (Cassis de Dijon), [1979] ECR 646.

${ }^{47}$ See for example Jukka Snell: Freedom to provide Services under the Services Directive compared to the existing case law of the ECJ, in Ulla Neergaard, Ruth Nielsen and Lynn Roseberry (eds.): The Services Directive - Consequences for the Welfare State and the European Social Model, Copenhagen 2008.

${ }^{48}$ Pursuant to Vassilis Hatzopoulos: A (More) Social Europe: A Political Crossroad or a Legal One-Way? Dialogues between Luxembourg and Lisbon, Common Market Law Review, 2005, 1600, who refers to: Commission of the European Communities: European Social Policy - A Way forward for the Union - A White Paper, COM(94) 333, Brussels 27.07.1994. Here it is stated in the "Preface": "The objective in the coming period must be to preserve and develop the European social model as we move towards the 21st century, to give to the people of Europe the unique blend of economic well-being, social cohesiveness and high overall quality of life which was achieved in the post-war period.” Also see e.g. Nick Adnett \& Stephen Hardy: The European Social Model. Modernisation or Evolution?, Edward Elgar, 2005.

${ }^{49}$ Vassilis Hatzopoulos: A (More) Social Europe: A Political Crossroad or a Legal One-Way? Dialogues between Luxembourg and Lisbon, Common Market Law Review, 2005, p. 1634.

${ }^{50}$ See in this regard Vassilis Hatzopoulos: A (More) Social Europe: A Political Crossroad or a Legal One-Way? Dialogues between Luxembourg and Lisbon, Common Market Law Review, 2005, pp. 1599-1635.

${ }^{51}$ Jo Shaw: Introduction, in Jo Shaw (ed.): Social Law and Policy in an Evolving European Union, London, 2000, p. 3.

${ }^{52}$ Henning Jørgensen \& Per Kongshøj Madsen: Flexicurity and Beyond. Finding a New Agenda for the European Social Model, DJØF Publishing, 2007, p. 25, who point out that already in 1985 Jacques Delors introduced a social dimension of the EU.

${ }^{53}$ Elias Mossialos \& Martin McKee: EU Law and the Social Character of Health Care, P.I.E. Peter Lang, 2004, p. 41.
} 
say, globalization, is logically inconsistent. Rather, what European (supra-national) social policy seeks to do is to create a European social model - either by synthesising aspects of all four models or (more realistically) by imposing one model on all. In an analogous way to the national myths that create and sustain both nationalism and nations, the idea of a 'European Social Model' should be considered perhaps as a founding myth which helps to create (not defend) the concept and reality of ‘Europeanisation’ and a politically integrated Europe.” ${ }^{54}$

In this line of argument, Philine ter Haar \& Copeland on the basis of a historical institutionalist analysis define the European Social Model as a mixture of hard law, soft law and underlying norms and values. ${ }^{55}$ Also, the integration capacity of the European Social Model acquis is presumed to be much weaker than that of the Internal Market. ${ }^{56}$

There is no consensus among legal scholars on how the concept of the European Social Model should be defined. There are different contributions in the Blurring Boundaries books to a conceptual clarification in regard to the European Social Model. ${ }^{57}$ Among these, it may be mentioned that Schiek states that the European Social Model should be defined as being based on commonalities between the Member States:

\begin{abstract}
"It has been characterised as an 'essence of a common political culture (...) which finds it difficult to accept the phenomena of exclusion and excessive inequality, which believes in the legitimacy of state intervention in redressing adverse consequences of the Market Economy in this respect and (...) in (...) a sufficient involvement of social partners', as a combination of 'economic efficiency and generous social insurance' and as the 'broad acknowledgement of three common features shared by every European state: (...) public commitment to social justice (...) the theoretical approach that social justice is not opposed to economic efficiency (...) and the value of interest representations and negotiations between social actors'." 58
\end{abstract}

Finally, the scheme of Maduro on models of Social Europe may be taken into account. He distinguishes between the following three models: 1) The model on economic freedom and social non-discrimination; 2) the model protecting the social model of the Member States; and 3) the social model of Europe. ${ }^{59}$ These three models review the relationship between the constitutionalisation of the project of European integration and social values. ${ }^{60}$ It is stressed that the models are heuristic devices rather than 'real-life' representations, and that elements of all are to be

\footnotetext{
${ }^{54}$ Mark Kleinman: A European Welfare State? European Union Social Policy in Context, Palgrave, 2002, p. 58.

${ }^{55}$ Beryl Philine ter Haar \& Paul Copeland: What are the Future Prospects for the European Social Model? An Analysis of EU Equal Opportunities and Employment Policy, European Law Journal, Vol. 16, No. 3, 2010, p. 274.

${ }^{56}$ Ibid.

${ }^{57}$ See in particular Dagmar Schiek: The European Social Model and the Services Directive in Ulla Neergaard, Ruth Nielsen and Lynn Roseberry (eds.): The Services Directive - Consequences for the Welfare State and the European Social Model", DJØF Publishing, 2008; Christian Joerges: A Renaissance of the European Economic Constitution?, and Dragana Damjanovic \& Bruno de Witte: Welfare Integration through EU Law: The Overall Picture in the Light of the Lisbon Treaty in Ulla Neergaard, Ruth Nielsen and Lynn Roseberry (eds.): Integrating Welfare Functions into EU Law - From Rome to Lisbon, DJØF Publishing, 2009; Hans-W. Micklitz: Judicial Activism of the European Court of Justice and the Development of the European Social Model in AntiDiscrimination and Consumer Law, and Dagmar Schiek: Is There a Social Ideal of the European Court of Justice? in Ulla Neergaard, Ruth Nielsen and Lynn Roseberry (eds.): The Role of Courts in Developing a European Social Model - Theoretical and Methodological Perspectives, DJØF Publishing, 2010.

${ }^{58}$ Dagmar Schiek: The European Social Model and the Services Directive, in Ulla Neergaard, Ruth Nielsen and Lynn M. Roseberry (eds.): The Services Directive - Consequences for the Welfare State and the European Social Model, DJØF Publishing, 2007 , p. 26. Footnotes have been omitted from the quotation.

${ }^{59}$ Miguel Poiares Maduro: European Constitutionalism and Three Models of Social Europe, in Martijn W. Hesselink (ed.): The Politics of a European Civil Code, Kluwer Law International, 2006, pp. 125-141.

${ }^{60}$ Op cit, p. 125.
} 
found to a greater or lesser extent in the European Union. ${ }^{61}$ It is also stressed that they do not simply represent different understandings of the role and place that social values ought to have in the project of European integration, because they embody different processes of decision-making with respect to social values in the European Union and these processes provide, in turn, different degrees of participation to different social groups. ${ }^{62}$

The first model more precisely is said to arise from the constitutionalisation of market integration. ${ }^{63}$ Accordingly, in this model the focus is on the fact that market integration rules constituted the basis for the initial process of constitutionalisation of the project of European integration, and that they shaped its impact on the European Social Model. ${ }^{64}$ Therefore, in this model both the impact of EU law on national social values and the development of European social values are linked to the logic of market integration and its focus on negative integration. ${ }^{65}$ The second model more precisely is said to have grown out of the policies of social harmonisation. ${ }^{66}$ Here, the European Social Model is viewed as a set of basic social values and rules which are promoted or set by the European Union, but are mainly to be guaranteed and protected by the Member States. ${ }^{67}$ Maduro points out that this model either aims at guaranteeing a level playing field in the social sphere so as prevent social deregulation at the Member State level or, in certain Member States, attempts to promote further social regulation by shifting the level of decisionmaking of national social policies to what is perceived to be a more social-friendly political sphere. ${ }^{68}$ Finally, the third model assumes that the European Social Model must entail both a definition of genuinely European social values and mechanisms of distributive justice at the European level: ${ }^{69}$

\begin{abstract}
'The underlying idea is that the European Union needs a political identity and that the latter requires a European definition of a core set of social values (including, in this respect, some core aspects of private law). It can also be argued that the increased redistributive consequences of some EU policies and its increased majoritarian character require a criterion and policies of distributive justice so as to legitimize and compensate for those redistributive consequences and to guarantee the necessary political loyalty of those in the minority. This model would require harmonization policies not as instruments of market integration (to guarantee a level playing field) but as instruments of a set of European social values that the Union ought to pursue. It would also require further instruments of distributive justice at the EU level (including taxation mechanisms).' 70
\end{abstract}

At the overall level, mainly the first and the second model are present. The third model still seems further away. In this respect, it is central that a right as such for Europe to legitimately establish and exercise an independent redistributive function is not recognised.

\footnotetext{
${ }^{61}$ Op cit, p. 125.

${ }^{62}$ Op cit, p. 127.

${ }^{63}$ Ibid. p. 125.

${ }^{64}$ Idem. p. 125. Pursuant to Maduro, this concept refers in this context both to the social model of the European States and that of the European Union itself.

${ }^{65}$ Ibid. p. 125.

${ }^{66}$ Idem.

${ }^{67}$ Idem.

${ }^{68}$ Ibid. pp. 125-126.

${ }^{69}$ Ibid. p. 126.

${ }^{70}$ Ibid. p. 126.
} 
Closely related to the concept of European Social Model is the concept of Social Market Economy. In that context, it may be worth pointing out that the Court of Justice of the European Union (hereinafter in his paper the ECJ) has ruled in Laval that:

\begin{abstract}
'Since the Community has thus not only an economic but also a social purpose, the rights under the provisions of the EC Treaty on the free movement of goods, persons, services and capital must be balanced against the objectives pursued by social policy, which include, as is clear from the first paragraph of Article 136 EC, inter alia, improved living and working conditions, so as to make possible their harmonisation while improvement is being maintained, proper social protection and dialogue between management and labour. ${ }^{, 71}$
\end{abstract}

It is likely that these sentences - as well as the judgment itself in its entirety as well as other sources of law including soft law - may be understood as an expression of "social market economy" as already, i.e. before the entering into force of the Lisbon Treaty, being the actual objective of the EU to strive for. ${ }^{72}$ This point of view also seems supported e.g. by the quotation above from the older Defrenne-II judgment. After the Treaty of Lisbon has entered into force, this objective is explicitly introduced, namely in Article 3(3) EU:

'The Union shall establish an internal market. It shall work for the sustainable development of Europe based on balanced economic growth and price stability, a highly competitive social market economy, aiming at full employment and social progress, and a high level of protection and improvement of the quality of the environment. It shall promote scientific and technological advance. It shall combat social exclusion and discrimination, and shall promote social justice and protection, equality between women and men, solidarity between generations and protection of the rights of the child. It shall promote economic, social and territorial cohesion, and solidarity among Member States. It shall respect its rich cultural and linguistic diversity, and shall ensure that Europe's cultural heritage is safeguarded and enhanced.'

In other words, it is hereby expressly indicated that "social market economy" is what the Union should work for. ${ }^{73}$ However, there is also a condition inserted which could have some importance, namely 'highly competitive'. Under all circumstances, it seems noteworthy that 'social market

\footnotetext{
${ }^{71}$ Judgment of 18 December 2007 in Case C-3141/05, Laval un Partneri Ltd v Svenska Byggnadsarbetareförbundet, Svenska Byggnadsarbetareförbundets avdeling 1, Byggettan, Svenska Elektrikerförbundet, Para. 105. Also see Judgment of 11 December 2007 in Case C-438/05, International Transport Workers’ Federation, Finnish Seamen's Union v Viking Line ABP, OÜ Viking Line Eesti, Para. 79.

${ }^{72}$ See further e.g. Loïc Azoulai: The Court of Justice and the Social Market Economy: The Emergence of an Ideal and the Conditions for Its Realization, Common Market Law Review, 2008, pp. 1335-1356; and Catherine Jacqueson: Social dumping i EU - på vej mod en social markedsøkonomi?, Juristen, nr. 5-6, 2009.

${ }^{73}$ It should be noted that the former Article 3(1), litra g) EC, states that the activities of the Community shall include: '... a system ensuring that competition in the internal market is not distorted...” In the Lisbon Treaty this aim could be said to be "moved" to Protocol 27 with the following content: "The High Contracting Parties, considering that the internal market as set out in Article 3 of the Treaty on European Union includes a system ensuring that competition is not distorted...' Apparently, the legislative history of this change is that in particular the French president Sarkozy fought for the insertion of an aim of 'social market economy'. This concept has pursuant to Christian Joerges \& Florian Rödl: 'Social Market Economy' as Europe’s Social Model?, EUI Working Paper LAW No. 2004/8 (European University Institute, Florence, Department of Law, 2004) 10, its EU roots back to the Convention preparing the Reform Treaty, which to a certain degree by now has become the Lisbon Treaty. However, Commission officials should have been responsible for at least keeping the aim of undistorted competition in a protocol. Normally, in EU law a protocol to a Treaty will be considered severe interpretational weight - at times even equal weight with Treaty provisions - but how much weight it should be given in the present situation, where it is not completely easy to reconcile the two different aims, is not too easy to predict about. It could seem as if the aim of undistorted competition should be viewed as rather inferior to the aim of a social market economy, but nothing is certain at all. Also see Peter Behrens: Der Wettbewerb im Vertrag von Lissabon, Europäische Zeitschrift für Wirtschaftsrecht EuZW 7/2008, 193; and Constanze Semmelmann: The future role of the non-competition goals in their interpretation of Article 81 EC, Global Antitrust Review, 2008, 15-47.
} 
economy' will play an explicit and significant role. By the insertion of this objective, it is likely that a more horizontal acceptance of it may be expected, e.g. also having consequences to an area such as competition law, although this is an area which to an almost extreme degree is dominated by economic theory and the aims defined therein such as efficiency. Thereby, a culmination of the development away from the original point of departure as a mere economic integrationist community with a focus on, primarily, a system of undistorted competition, to a rather new situation, has explicitly taken place. ${ }^{74}$ The development of the Treaty texts can be seen as a step towards constitutionalising the European Social Model.

It is possible that the concept 'social market economy' may be viewed as an important expression of a compromise between the opposing views which exist, and which in simplified terms may be identified as forces aiming for hard liberalisation, etc., and the forces aiming at keeping a kind of status quo, in any case viewed as comprised of the more socially concerned forces. ${ }^{75}$ However, the launching of the concept does not provide any solution to the tensions at stake, as the opposing interests may be viewed as being expressed within the construction thereof ('social economy' versus 'market economy'). Also, as expressed by Joerges \& Rödl, there is neither a common nor a clear picture of what the world could be in a 'social market economy', nor what constitutes appropriate steps to advance towards it. ${ }^{76}$ The only certain claim to be put forward with some right is that a commitment to a market economy with a social dimension may be viewed as a fact by now. ${ }^{77}$

To us the importance of the European Social Model and the Social Market Economy primarily lies in the function of indicating that Europe is now heading in a different direction than what it originally did. The social dimension of the EU will make the European project more acceptable to some than when it was primarily defined as an economic project. However, this change also unavoidably implies a larger impact - and at times limitations - on the national organisation of welfare, which will be perceived negatively by others. As it has been put forward by Damjanovic \& de Witte, the EU's legitimacy to deal with welfare services is disputed and uneven. ${ }^{78}$ References to the abovementioned concepts signify this change. Static definitions are not possible to formulate at

\footnotetext{
${ }^{74}$ See Christian Joerges: What is Left of the European Economic Constitution?, EUI Working Paper LAW No. 2004/13 (European University Institute, Florence, Department of Law, among others at pp. 16-17, where it is stated that: "The ordo-liberal European polity has a twofold structure: at supranational level, it is committed to economic rationality and a system of undistorted competition. At national level, re-distributive (social) policies may be pursued and developed further. To summarize: Europe was constituted as a dual polity. Its 'economic constitution' was un-political in the sense that it was not subject to political interventions. This was its constitutional-supranational raison d'être. Social policy was treated as a categorically distinct subject... Domain of political legislation and, thus, had to remain national. The social embeddedness of the market could, and should, be accomplished by the Member States in differentiated ways - and, for a decade or so, the balance seemed stable. [Footnote omitted]"

${ }^{75}$ See Christian Joerges \& Florian Rödl: 'Social Market Economy' as Europe's Social Model?, EUI Working Paper LAW No. 2004/8 (European University Institute, Florence, Department of Law, 2004) 11-12, who believe that “... it receives political and constitutional significance when the Convention makes the intended social character of the European Union explicit with a reference to 'social market economy'...”

${ }^{76}$ Ibid.

${ }^{77}$ Also see Christian Joerges: A Renaissance of the European Economic Constitution?, in Ulla Neergaard, Ruth Nielsen and Lynn M. Roseberry (eds.): Integrating Welfare Functions into EU Law - From Rome to Lisbon, DJØF Publishing Copenhagen, 2009, p. 29; or Dragana Damjanovic \& Bruno de Witte: Welfare Integration through EU Law: The Overall Picture in the Light of the Lisbon Treaty, in: Ulla Neergaard, Ruth Nielsen and Lynn Roseberry (eds.): Integrating Welfare Functions into EU Law - From Rome to Lisbon, Djøf Publishing Copenhagen, 2009, p. 85.

${ }^{78}$ Dragana Damjanovic \& Bruno de Witte: Welfare Integration through EU Law: The Overall Picture in the Light of the Lisbon Treaty, in: Ulla Neergaard, Ruth Nielsen and Lynn Roseberry (eds.): Ulla Neergaard, Ruth Nielsen and Lynn Roseberry (eds.): Integrating Welfare Functions into EU Law - From Rome to Lisbon, DJØF Publishing, 2009, p. 55.
} 
the present level of development. Also, what the concrete impact on the Danish welfare state will be from the visions behind the concepts will only the future provide us with clear knowledge of. Thus, the claimed blurred boundaries between the Danish welfare state and EU law seem confirmed. ${ }^{79}$ It is likely that the European Social Model will not replace the welfare states of Member States. ${ }^{80}$ However, although the direction of movement is not entirely clear, it seems as if the dominating ideology is still based on a commitment to a market economic ideology, and yet, a concept like solidarity has started playing an important role in the definition of the European identity, and may slowly become viewed as indicating an ideal or even an aspect of an ideology, which may eventually be given weight. ${ }^{81}$ Also, there is no such evidence that the former is to be substituted by the latter. Rather, they will influence one another. However, as it will be demonstrated in what follows, the case law and other sources of law will give some further indications of severe impact.

\section{Balancing Primary EU Law on Free Movement against - National or EU - Welfare Rights}

The expression 'primary EU law on free movement' refers in this paper ${ }^{82}$ mainly to Articles 18 FEU (the general prohibition of discrimination on ground of nationality), ${ }^{83}$ Article 21 FEU (free

\footnotetext{
${ }^{79}$ In the same direction, e.g. Dragana Damjanovic \& Bruno de Witte: Welfare Integration through EU Law: The Overall Picture in the Light of the Lisbon Treaty, in: Ulla Neergaard, Ruth Nielsen and Lynn Roseberry (eds.): Integrating Welfare Functions into EU Law - From Rome to Lisbon, DJØF Publishing, 2009, p. 91, express the following: “... [I]t is likely that in the years to come the European Union will become ever more a 'multi-level welfare system' [footnote omitted] in which the states will continue to occupy a leading role in terms of organisation and funding of welfare services and in which the European Union will play a growing role in setting limits and providing incentives across a wide variety of welfare sectors”. Further, e.g. Mark Kleinman: A European Welfare State? European Union Social Policy in Context, Palgrave, 2002, p. 225, states: 'Europeans will continue to want a high quality of welfare, and by and large, will be prepared to pay for it. But 'Europeans' will continue to be diverse. Integration cannot and should not eradicate the different cultures of Europe. Past and present migrations will increase Europe's ethnic and cultural mix. So welfare systems will continue to be diverse. The policy task is not to try to homogenise these differences, but to find ways of better linkage and better learning across countries and systems. In this way, European welfare will continue to increase, without the need for a European welfare state.' Furthermore, reference should be made to Hans-W. Micklitz: Judicial Activism of the European Court of Justice and the Development of the European Social Model in Anti-Discrimination and Consumer Law, in Ulla Neergaard, Ruth Nielsen and Lynn Roseberry (eds.): The Role of the Courts in Developing a European Social Model. Theoretical and Methodological Perspectives, DJØF Publishing, 2010, p. 28, who asserts that: “1. The ECJ is developing, on the basis of the acquis communautaire, a European Social Framework, not a fully-fledged European Social Model. 2. The ECJ's Social Model is based on access justice not on social justice. 3. More recently, the ECJ tends to substitute national social models with it won European Social Model.” Finally, also see e.g. Michael Dougan: The Spatial Restructuring of National Welfare States within the European Union: The Contribution of Union Citizenship and the Relevance of the Treaty of Lisbon, in: Ulla Neergaard, Ruth Nielsen and Lynn Roseberry (eds.): Integrating Welfare Functions into EU Law - From Rome to Lisbon, DJØF Publishing, 2009, pp. 147-187.

${ }^{80}$ Beryl Philine ter Haar \& Paul Copeland: What are the Future Prospects for the European Social Model? An Analysis of EU Equal Opportunities and Employment Policy, European Law Journal, Vol. 16, No. 3, 2010, p. 281, who also state: The European Social Model rather “... complements ... them and creates convergence and harmonization in some policy areas by establishing a framework in which they can be reformed. Nevertheless, there remains a fundamental difference between the ESM and the Single Market in that the Single Market forms the bulk of acquis communautaire which is upheld by the Commission and the Court of Justice of the European Communities (ECJ) by means of judicial review...”.

${ }^{81}$ Ulla Neergaard: In Search of the Role of 'Solidarity' in Primary Law and the Case Law of the European Court of Justice, in Ulla Neergaard, Ruth Nielsen and Lynn Roseberry (eds.): The Role of the Courts in Developing a European Social Model. Theoretical and Methodological Perspectives, DJØF Publishing, 2010, pp. 99-140. Also see Dagmar Schiek: Is there a Social Ideal of the European Court of Justice?, in Ulla Neergaard, Ruth Nielsen and Lynn Roseberry (eds.): The Role of the Courts in Developing a European Social Model. Theoretical and Methodological Perspectives, DJØF Publishing, 2010, p. 98, who stresses that: 'Concerning the question in how far markets should be regulated, a public sector should be maintained and structural detriment on markets should be counteracted, the court seems to expose some degree of an ideology based on its commitment to constitutionalising the internal market. Mainly, markets are portrayed as working better than public regulation. This is not always supported by legal rules, but partly also related as eternal truth... Thus, while market and commercial principles do enjoy a certain priority, other principles can at times rise to the fore.'

${ }^{82}$ See further Von Bogdandy, Armin: Founding Principles of EU Law: A Theoretical and Doctrinal Sketch, European Law Journal, 2010 p. 95.
} 
movement of union citizens), Article 34 FEU (free movement of goods), Article 45 (free movement of workers), Article 49 FEU (freedom of establishment), Article 56 FEU (free movement of services) and Article 63 FEU (free movement of capital), the case law of the ECJ on free movement in the EU and the general principles of EU law. ${ }^{84}$

In this section we will discuss different aspects of the interrelation between national or EU welfare law on the one side and EU free movement law on the other side, and the contributions to their understanding that can be found in the Blurring Boundaries project. We will discuss them under the following headings:

1) Narrow or expansive interpretation on the free movement provisions in EU primary law

2) From a narrow ban on direct or indirect discrimination to a broader ban on restriction

3) Justification of welfare related restrictions/discriminations (legitimate aims, the principle of proportionality)

4) Free movement and fundamental social/welfare rights

5) The Services Directive

\subsection{Narrow or Expansive Interpretation of the Free Movement Provisions in EU Primary} Law

One way of avoiding a conflict between welfare law at national level and free movement law at EU level would be to put a narrow interpretation on the free movement provisions and regard welfare rights as (largely) outside the scope of application of primary EU law on free movement. In regard to EU competition law, national welfare law has to a certain degree been shielded off from EU law in this way.

\subsubsection{Welfare Law and the Scope of Competition Law}

In the context of competition law, the ECJ has held that the concept of an undertaking encompasses every entity engaged in an economic activity, regardless of the legal status of the entity and the way in which it is financed. ${ }^{85}$ In Poucet and Pistre, the ECJ held that the concept of an undertaking did not encompass organisations charged with the management of certain compulsory social security schemes, based on the principle of solidarity. Under the sickness and maternity scheme forming part of the system in question, the benefits were the same for all beneficiaries, even though contributions were proportional to income; under the pension scheme, retirement pensions were funded by workers in employment; furthermore, the statutory pension entitlements were not proportional to the contributions paid into the pension scheme; finally, schemes with a surplus contributed to the financing of those with structural financial difficulties. That solidarity made it necessary for the various schemes to be managed by a single organisation and for affiliation to the schemes to be compulsory. In contrast, in Fédération Française des Sociétés d'Assurance, the ECJ held that a non-

\footnotetext{
${ }^{83}$ Article 21(2) of the Charter on Fundamental Rights of the European Union also contains a ban on nationality discrimination.

${ }^{84}$ See generally Groussot, Xavier: Creation, Development and Impact of the General Principles of Community Law: Towards a jus commune europaeum?, Lund 2005 (Swedish jur. dr. thesis), an abbreviated version is published as Groussot, Xavier: General Principles of Community Law, Amsterdam 2006, Tridimas, Takis: The General Principles of EC Law, Oxford 1999 and Usher, John A.: General principles of EC law, London 1998.

${ }^{85}$ See, in particular, Case C-41/90 Höfner and Elser [1991] ECR I-1979, Joined Cases C-159 \& 160/91, Poucet et Pistre v Assurances Générales de France [1993] ECR I-637 and Case C-244/94 Fédération Française des Sociétés d'Assurance and Others v Ministère de l'Agriculture et de la Pêche [1995] ECR I-4013. See further Nina Boeger: Solidarity and EC Competition Law, European Law Review 2007, p. 319.
} 
profit-making organisation which managed a pension scheme intended to supplement a basic compulsory scheme, established by law as an optional scheme and operating according to the principle of capitalisation, was an undertaking within the meaning of the competition rules. Optional affiliation, application of the principle of capitalisation and the fact that benefits depended solely on the amount of the contributions paid by the beneficiaries and on the financial results of the investments made by the managing organisation implied that that organisation carried on an economic activity in competition with life assurance companies. Neither the social objective pursued, nor the fact that it was non-profit-making, nor the requirements of solidarity, nor the other rules concerning, in particular, the restrictions to which the managing organisation was subject in making investments altered the fact that the managing organisation was carrying on an economic activity.

In Albany, Brentjens and Drijvende Bokken, ${ }^{86}$ the ECJ dealt with the question whether compulsory affiliation to a sectoral pension scheme set up by collective agreement was compatible with competition rules. The answer it gave was that EU competition rules do not prohibit a decision by the public authorities to make affiliation to a sectoral pension fund compulsory at the request of organisations representing employers and workers in a given sector. A pension fund charged with the management of a supplementary pension scheme set up by a collective agreement concluded between organisations representing employers and workers in a given sector, to which affiliation has been made compulsory by the public authorities for all workers in that sector, is an undertaking within the meaning of EU competition rules. These rules do not preclude the public authorities from conferring on a pension fund the exclusive right to manage a supplementary pension scheme in a given sector. On 17 November 2000, the Danish Labour Court delivered a ruling ${ }^{87}$ where it directly applied the Albany case law. A small employer - a taxicab owner with 7-8 chauffeurs - was bound by a collective agreement containing pension provisions. The employer refused to pay the employers' contribution to the pension scheme and paid the employee contribution directly to the individual workers and not to the pension scheme. He claimed that the pension scheme was invalid as incompatible with both Danish and EU competition law. He requested a reference to the ECJ to clarify the law claiming inter alia that the Danish collective agreement system differs from the Dutch one at issue in Albany et al. The Danish Labour court refused to refer questions to the ECJ. It held in its judgement on 17 November 2000 that there was no relevant difference between Albany (and the other cases decided by the ECJ on the same date) and the Danish case. The Danish collective agreement at issue was therefore considered outside the scope of the competition rules. During the case, the two main organisations on the Danish labour market (LO and DA, who in accordance with the Danish tradition in labour law constitute the main 'legislator' in the labour market; see below in section 7) stood together in support of their collective agreement, which was

\footnotetext{
${ }^{86}$ Case C-67/96 Albany International [1999] ECR I-5751, Joined Cases C-115/97, C-116/97 and C-117/97 Brentjens [1999] ECR I6025, and Case C-219/97 Drijvende Bokken [1999] ECR I-6121.

${ }^{87}$ AD 1996.225, Landsorganisationen i Danmark (LO, The Danish Confederation of Trade Unions) for Specialarbejderforbundet $i$ Danmark (SiD) for Chaufførernes Fagforening v taxicab owner Munir Ali Lanewala, Intervener DA, Dansk Arbejdsgiverforening (the Danish Employers' Association) in support of LO.
} 
violated by a small, unorganised employer who had signed it but claimed that it was not binding for him because it - in his view - was contrary to EU competition law. ${ }^{88}$

\subsubsection{Welfare Law and the Scope of EU Primary Law on Free Movement}

It is probably contrary to the case law of the ECJ to put the same construction on EU internal market law as that applied in regard to competition law and regard national welfare law as outside the reach of EU free movement law. The Danish and Swedish governments did, without success, argue for such an interpretation in Laval. In Laval, ${ }^{89}$ the Danish and Swedish Governments submitted that the right to take collective action in the context of negotiations with an employer falls outside the scope of Article 56 FEU [ex Article 49 EC], since, pursuant to Article 153(5) FEU [ex Article 137(5) EC]. On this point, the ECJ held:

87 In this regard, it suffices to point out that, even though, in the areas in which the Community does not have competence, the Member States remain, in principle, free to lay down the conditions for the existence and exercise of the rights at issue, they must nevertheless exercise that competence consistently with Community law (see, by analogy, as regards social security, Case C-120/95 Decker [1998] ECR I-1831, paragraphs 22 and 23, and Case C-158/96 Kohll [1998] ECR I-1931, paragraphs 18 and 19; as regards direct taxation, Case C-334/02 Commission v France [2004] ECR I-2229, paragraph 21, and Case C-446/03 Marks \& Spencer [2005] ECR I-10837, paragraph 29).

88 Therefore, the fact that Article 137 EC does not apply to the right to strike or to the right to impose lock-outs is not such as to exclude collective action such as that at issue in the main proceedings from the domain of freedom to provide services.

The Danish and Swedish Governments also argued that the right to take collective action constitutes a fundamental right which, and as such, falls outside the scope of Article 56 FEU and the Posting of Workers Directive. ${ }^{90}$ In that regard, the ECJ recalled that the right to take collective action is recognised both by various international instruments which the Member States have signed or cooperated in, such as the European Social Charter, signed at Turin on 18 October 1961 - to which, moreover, express reference is made in Article 151 FEU - and Convention No 87 of the International Labour Organisation concerning Freedom of Association and Protection of the Right to Organise of 9 July 1948 - and by instruments developed by those Member States at EU level, such as the Community Charter of the Fundamental Social Rights of Workers adopted at the meeting of the European Council held in Strasbourg on 9 December 1989, which is also referred to in Article 151 FEU, and the Charter of Fundamental Rights of the European Union; see further below in section 7 . Although the right to take collective action must therefore be recognised as a fundamental right which forms an integral part of the general principles of Community law, the observance of which the ECJ ensures, the exercise of that right may, in the view of the ECJ, none the less be subject to certain restrictions. As is reaffirmed by Article 28 of the Charter of Fundamental Rights of the European Union, it is to be protected in accordance with EU law and national law and practices. The ECJ concluded on this point:

\footnotetext{
${ }^{88}$ See further Nielsen, Ruth: Europeanization of Nordic Labour Law in Scandinavian Studies in Law Volume 43, Stability and Change in Nordic Labour Law, Stockholm 2002 p. 37.

${ }^{89}$ Case C-341/05 Laval and Partneri [2007] ECR I-11767.

90 96/71/EC.
} 
95 It follows from the foregoing that the fundamental nature of the right to take collective action is not such as to render Community law inapplicable to such action, taken against an undertaking established in another Member State which posts workers in the framework of the transnational provision of services.

96 It must therefore be examined whether the fact that a Member State's trade unions may take collective action in the circumstances described above constitutes a restriction on the freedom to provide services, and, if so, whether it can be justified.

The Laval judgment has given rise to much debate; see below in section 6.3. It is still a contested issue how broadly the free movement provisions should be interpreted when they contrast with the trade unions' fundamental rights. In a pending infringement case ${ }^{91}$ against Germany, the Commission seeks an order declaring that Germany has infringed the procurement directives ${ }^{92}$ because local authorities and local authority undertakings awarded public service contracts concerning occupational pension schemes without a European call for tenders directly to the organisations and undertakings mentioned in a collective agreement. In Germany, employees have the right to demand that part of their future earnings are paid into their occupational pension schemes through the conversion of earnings into pension contributions (Entgeltumwandlung).

According to the Commission, German local authorities and local authority undertakings should not have awarded public service contracts relating to occupational pensions schemes to organisations and undertakings mentioned in the collective agreement, but rather after issuing a European call for tenders. In the initial stages of the infringement case (the formal notice and the reasoned opinion to Germany), the Commission took the view that Germany had violated both the procurement directive(s) and the basic Treaty provisions on free movement (Article 49 FEU on freedom of establishment and Article 56 FEU on free movement of services). In the case pending before the ECJ, the Commission is, however, limiting its claim to seeking a declaration that Germany has violated the procurement directive(s).

The German government argues that the Commission is interfering with the autonomy of the social partners (Tarifautonomie) and that it follows from an analogy from Albany that collective agreements such as those at issue in the pending case are outside the scope of EU free movement law. The Commission cannot see how, if contracting authorities were to fulfil their obligation to put contracts out to public tender, this would limit the application of the principle of collective bargaining autonomy (Tarifautonomi).

In Denmark, most public sector employees are - under collective agreements - entitled to pension contributions from their employers as part of their wages. The pension contributions are paid to pension providers designated by the collective agreements without putting pension schemes out to public tender. The pending German case is therefore highly relevant for Denmark. Denmark and Sweden intervened in the case in support of Germany. The Danish and Swedish governments referred to an analogy from Albany and defended the position that the social partners are autonomous to conclude collective agreements including on how they set up supplementary pension systems as part of the collective agreement.

\footnotetext{
${ }^{91}$ Case C-271/08 Commission v Germany pending.

${ }^{92}$ Until 31 January 2006 Article 8 in conjunction with Titles III to VI of Directive 92/50/EEC and since 1 February 2006 Article 20 in conjunction with Articles 23 to 55 of Directive 2004/18/EEC.
} 
The Advocate General (Verica Trstenjak) delivered her opinion 14 April 2010. On the issue of the interplay between free movement rights and the right to collective bargaining, she held - relying on Laval - that the right to collective bargaining is a fundamental social right but that the fundamental nature of the right to collective bargaining does not render EU law on free movement inapplicable. Free movement and the right to collective bargaining must be balanced against each other. If a matter is within the scope of application of the procurement directive, the EU legislator has struck that balance in favour of free movement. She found, however, that the Commission had failed to prove that the contested contracts had a value exceeding the threshold in the procurement directive(s). It was thus not proven that the matter at issue was within the scope of application of the procurement directives. In her opinion, the Commission could therefore not obtain a declaration that Germany had violated the procurement directives.

\subsubsection{The ECJ's Expansive Interpretation of Free Movement Law}

As Jukka Snell states in his contribution to the Blurring Boundaries project, ${ }^{93}$ one of the most remarkable developments in the EU single market law has been the expansive interpretation given to the free movement of services by the ECJ. In his view, this case law has shifted the institutional balance in the EU in the field of liberalisation of services. It is, however, still a contested issue how broadly the free movement provisions should be interpreted, especially when they contrast with fundamental rights; see below in section 4.4.

Article 57 FEU includes services within the remit of the FEU Treaty if they are 'normally provided for remuneration'. This was originally understood in Humbel ${ }^{94}$ as excluding a course provided under a national system of secondary education. The ECJ, which followed Advocate General Slynn, reasoned that the state was not seeking to make a profit but was simply fulfilling its duty towards its own population and, as a general rule, the system was funded from the public purse, even if certain enrolment fees had to be paid by the parents or pupils. As a result, the situation was not covered by the Treaty rules on free movement of services, and Belgium was free to charge a foreign student a fee that domestic students did not have to pay. In Wirth, the ECJ held that courses given in an establishment of higher education which is financed essentially out of public funds do not constitute services within the meaning of the then Article 49 EC [now 56 FEU]. In Neri, ${ }^{95}$ the ECJ held that the organisation for remuneration of university courses is an economic activity falling within the chapter of the FEU Treaty dealing with the right of establishment when that activity is carried on by a national of one Member State in another Member State on a stable and continuous basis from a principal or secondary establishment in the latter Member State. The case law on tax-financed education could suggest that tax-financed welfare services fall outside the scope of EU free movement law. The exclusion of public services from the remit of the Treaty provisions on free movement was, however, reversed or at least severely limited in the more recent case law on health services. ${ }^{96}$

\footnotetext{
${ }^{93}$ Jukka Snell: Freedom To Provide Services in the Case Law and in The Services Directive: Problems, Solutions, and Institutions in Neergaard, Ulla, Ruth Nielsen and Lynn Roseberry (eds.): The Services Directive - Consequences for the Welfare State and the European Social Model, Copenhagen 2008.

${ }_{94}$ Case 263/86 Humbel [1988] ECR 5365.

${ }^{95}$ Case C-153/02 Neri [2003] I-13555 ground 39.

${ }^{96}$ See further Vassilis Hatzopoulos: Services of general interest in healthcare: an exercise in deconstruction? in Neergaard, Ulla, Ruth Nielsen and Lynn Roseberry (eds.): Integrating Welfare Functions into EU Law - From Rome to Lisbon, Copenhagen 2009.
} 
As mentioned above in the Introduction, the ECJ has, since the 1970's, held that the EU has a double aim, which is at once economic and social. ${ }^{97}$ The texts of the Treaty provisions on the fundamental free movement rights do, however, not mirror the interrelation between social and economic aims. The only reference to social aims is made in those provisions that allow Member States to restrict fundamental freedoms in favour of protecting public policy, public security and public health $^{98}$ as well as a number of other public interests in the case of free movement of goods. ${ }^{99}$ The existing EU rules on migrant workers comprise different rights and duties in different relationships: there is a ban on discrimination on grounds of nationality, rights to move and reside freely within the territory of other EU countries and a prohibition against restrictions also by one's own Member State on the free movement of workers.

There have been provisions on the free movement for workers and self-employed ${ }^{100}$ in the basic Treaties since the beginning of the EC/EU. They were supplemented by Regulations on the free movement of workers ${ }^{101}$ and social security for migrant workers and self-employed persons ${ }^{102}$ at an early stage of the Community's development. The basic Treaty-provision on free movement for workers is Article 45 FEU. ${ }^{103}$ Union citizenship was established by the Maastricht Treaty that came into force 1 November 1993. Every citizen of the Union has the right to move and reside freely within the territory of the Member States under Article 21 FEU, subject to the limitations and conditions laid down in the FEU Treaty and by the measures adopted to give it effect; see for more detail the Free Movement and Residence Directive. ${ }^{104}$ Under that directive, workers are entitled to move to and reside in another EU Member State. Union citizens who are not workers (or students) are only entitled to reside in another EU Member State for more than three months if they have sufficient resources for themselves and their family members not to become a burden on the social assistance system of the host Member State and have comprehensive sickness insurance cover in that state. Workers who belong to the core of the workforce will typically thereby earn an income which will give them sufficient resources to take care of themselves and their family. Job seekers and atypical workers may not have such resources. Notwithstanding this, they will in most cases be within the scope of the free movement for workers provisions. Already in 1964 in Unger, ${ }^{105}$ the ECJ stated that the term 'worker' must have an EU meaning. The ECJ has developed a broad concept of worker. Any person who pursues activities which are effective and genuine, to the

\footnotetext{
${ }^{97}$ The leading case is Defrenne-II, case 43/75 [1976] ECR 455.

${ }^{98}$ See Article 45 FEU, Article 52 FEU and Article 62 FEU.

${ }^{99}$ See Article 36 FEU.

${ }^{100}$ Now Article 39-52 EC.

${ }^{101}$ EEC/1612/68 with many amendments.

${ }^{102}$ See now EEC/883/2004 which from 1 May 2010 has replaced Regulation 1401/7.

${ }^{103}$ It reads: 1. Freedom of movement for workers shall be secured within the Union.

2. Such freedom of movement shall entail the abolition of any discrimination based on nationality between workers of the Member States as regards employment, remuneration and other conditions of work and employment.

3. It shall entail the right, subject to limitations justified on grounds of public policy, public security or public health:

(a) to accept offers of employment actually made;

(b) to move freely within the territory of Member States for this purpose;

(c) to stay in a Member State for the purpose of employment in accordance with the provisions governing the employment of nationals of that State laid down by law, regulation or administrative action;

(d) to remain in the territory of a Member State after having been employed in that State, subject to conditions which shall be embodied in implementing regulations to be drawn up by the Commission.

4. The provisions of this Article shall not apply to employment in the public service.

104 2004/38/EC.

105 Case 75/63 Unger v Bestuur [1964] ECR 1977.
} 
exclusion of activities on such a small scale as to be regarded as purely marginal and ancillary, is regarded as a 'worker'.

It is now (2010) settled case law that the concept of 'worker' in the context of free movement of workers must not be interpreted narrowly. In order to be eligible for welfare rights it is, however, not always enough to be a worker. There may be additional requirements of residence, ${ }^{106}$ real link and the like. ${ }^{107}$

\subsection{From a Ban on Discrimination on Grounds of Nationality to a Ban on Restrictions}

Originally EU law on free movement applied solely to direct and indirect nationality discrimination by the Member States, at least in regard to freedom of establishment, free movement of capital and free movement of workers. Over the years, ECJ case law has developed EU free movement law into a broad(er) ban on restrictions. In Gebhard, ${ }^{108}$ the ECJ held that national measures liable to hinder or make less attractive the exercise of fundamental freedoms guaranteed by the Treaty such as freedom of establishment must fulfil four conditions: they must be applied in a non-discriminatory manner; they must be justified by imperative requirements in the general interest; they must be suitable for securing the attainment of the objective which they pursue; and they must not go beyond what is necessary in order to attain it. As a result of the development of EU primary law on free movement into a broad ban on restrictions which include non-discriminatory restrictions, more welfare-oriented provisions will come within the scope of free movement law than what would be the case if only directly or indirectly discriminatory measures were covered by the free movement provisions. The controversies in the abovementioned cases, Laval ${ }^{109}$ and the pending infringement case $^{110}$ against Germany over the interplay between EU free movement law and collective agreements (which comply with Nordic and German labour law) are for example mainly about nondiscriminatory restrictions. The cases only arise because free movement law as it stands today (2010) prohibits restrictions and not only discrimination.

\subsection{Justification of Welfare Restrictions/Discriminations}

Welfare services covered by EU free movement provisions may be justified in accordance with the case law of the ECJ on justification of restrictions/discriminations. In broad terms restrictions and/or discriminations may be justified by reference to two different groups of legitimate aims: either the Treaty-based exceptions from the free movement provisions, in particular public policy, public security or public health, or by reference to all the overriding reasons relating to the public interest that are accepted in the case law of the ECJ following Dassonville ${ }^{111}$ and Cassis de Dijon, ${ }^{112}$ for example consumer protection and protection of workers. The general view is that

\footnotetext{
${ }^{106}$ In case C-127/08 Metock [2008] I-6241, the ECJ stated that there is only a right of family reunification for family members of a Union citizen who has exercised his right of freedom of movement by becoming established [emphasis added] in another Member State than his own.

${ }^{107}$ See for a more detailed analysis of ECJ case law Michael Dougan: The Spatial Restructuring of National Welfare States within the European Union: the Contribution of Union Citizenship and the Relevance of the Treaty of Lisbon and Ruth Nielsen: The Charter of Fundamental Rights and Migrant Workers' Welfare Rights, both in Ulla Neergaard, Ruth Nielsen and Lynn Roseberry (eds.): Integrating Welfare Functions into EU Law - From Rome to Lisbon, Copenhagen 2009.

${ }^{108}$ Case C-55/94 Gebhard [1995] ECR I-4165.

${ }_{109}$ Case C-341/05 Laval and Partneri [2007] ECR I-11767.

${ }^{110}$ Case C-271/08 Commission v Germany pending.

${ }^{111}$ Case 8/74 Procureur du Roi v. Benoît and Gustave Dassonville [1974] ECR 837.

${ }^{112}$ Case 120/78 Rewe v. Bundesmonopolzentralverwaltung [1979] ECR 649.
} 
direct discrimination can only be justified on grounds of the Treaty-based legitimate aims, while indirect discrimination and indiscriminate restrictions can be justified on the basis of all the overriding reasons relating to the public interest.

Article $52 \mathrm{FEU}^{113}$ only lists three possible grounds that could justify direct or indirect special treatment of foreign nationals, namely public policy, public security, and public health. The first heading, public policy, could potentially - especially if one focuses on the English language version, less so if one looks at the French (ordre public) or German (öffentliche Ordnung) versions - be open to a broad application encompassing all welfare policies. In practice, the ECJ has, however, defined the notion restrictively. In Bouchereau the ECJ held that Article 3(2) of the then directive 64/221/EEC, ${ }^{114}$ according to which previous criminal convictions did not in themselves constitute grounds for the imposition of the restrictions on free movement authorised by the then Article 48 EC [now Article 45 FEU] on grounds of public policy and public security, must be interpreted to mean that previous criminal convictions are relevant only in so far as the circumstances which gave rise to them are evidence of personal conduct constituting a present threat to the requirements of public policy. A simple breach of a law is not sufficient to justify the use of this concept; what is needed is the existence of 'a genuine and sufficiently serious threat to the requirements of public policy affecting one of the fundamental interests of society. ${ }^{, 115}$

In the Italian museum case, ${ }^{116}$ the ECJ declared that, by allowing discriminatory, advantageous rates for admission to museums, monuments, galleries, archaeological digs, parks and gardens in favour of Italian nationals and persons resident within the territory of the authorities running the cultural sites in question, who are aged over 60 or 65 years, and by excluding from such advantages tourists who are nationals of other Member States and non-residents who fulfil the same objective age requirements, the Italian Republic had failed to fulfil its obligations under Articles 12 EC [now 18 FEU] and Article 49 EC [now 56 FEU]. ${ }^{117}$

The Italian government put forward various reasons in the general interest in order to justify the advantageous rates at issue. First it contended, in the light of the cost of managing cultural assets, free admission to the sites cannot be granted in disregard of economic considerations. Second, the more favourable treatment afforded only to Italian nationals and certain residents is justified by reasons of cohesion of the tax system, in that those advantages constitute consideration for the payment of the taxes by which those nationals and residents contribute to the running of the sites concerned. The ECJ held, that to the extent that the advantageous rates at issue provide for a distinction on the basis of nationality, such advantages are compatible with EU law only if they can be covered by an express derogating provision, such as Article 52 FEU, namely public policy, public security or public health. Economic aims cannot constitute grounds of public policy within

\footnotetext{
${ }^{113}$ In the English version, Article 52 FEU reads: 'The provisions of this Chapter and measures taken in pursuance thereof shall not prejudice the applicability of provisions laid down by law, regulation or administrative action providing for special treatment for foreign nationals on grounds of public policy, public security or public health'. In the French version, the decisive words are: justifiées par des raisons d'ordre public, de sécurité publique et de santé publique, and in the German version: aus Gründen der öffentlichen Ordnung, Sicherheit oder Gesundheit gerechtfertigt sind.

${ }^{114}$ Now replaced by Directive 2004/38/EC on the right of citizens of the European Union and their family members to move and reside freely within the territory of the EU.

${ }_{115}$ Case 30/77 Bouchereau [1977] ECR 1999 para 35.

${ }_{116}$ Case C-388/01 Commission v Italy [2003] ECR I-721.

${ }^{117}$ See for a critical assessment of the Italian museum case Davies, Gareth: ‘Any Place I Hang My Hat?' or: Residence is the New Nationality, European Law Journal 2005 p. 43.
} 
the meaning of this article. ${ }^{118}$ The ECJ thus confirmed its practice that direct (nationality) discrimination can only be justified by reference to Treaty-based exceptions from the free movement provisions, in particular public policy, public security or public

Jukka Snell in his contribution to the Blurring Boundaries project concludes that an analysis of the ECJ case law on fundamental freedoms shows that the ECJ developed a multi-level system of interrelated aims of economic integration and general interests beyond the limited approach of the Treaty norms themselves. ${ }^{119}$

In addition to a legitimate aim, restrictions/discriminations must meet the requirements of the principle of proportionality, i.e. be appropriate and necessary in order to be justified. In practice, the ECJ has been prepared to accept most 'imperative reasons' advanced by Member States, but has analysed very carefully whether the conditions of appropriateness and necessity are fulfilled. In particular, the ECJ examines whether the same aim could be achieved by less restrictive means, ${ }^{120}$ such as through reliance on the requirements of the home state. ${ }^{121}$ According to Micklitz, ${ }^{122}$ the abundant case law of the ECJ lead to a silent Europeanisation of national social policies and contributed to the reshaping of the responsibilities of Member States and the EU in the European legal order. As he reads the judgments in Laval ${ }^{123}$ and Gysbrechts, ${ }^{124}$ the ECJ held that the higher national protection standards which reach beyond the EU minimum are violating the proportionality principle; see below in part 5 on the shift from minimum to maximum harmonisation.

When a Member State justifies national rules that hinder the exercise of free movement rights, it must not only show that the national rules fall within the Treaty exceptions (public policy, public security and public health) or overriding reasons of public interest but also that the national rules are consistent with fundamental rights, including the principle of non-discrimination; see below in sections 4.4. and 7. Some directives limit the margin of appreciation that can be used when making the justification test; see below in section 4.5. on the Services Directive. ${ }^{125}$ The Residence Directive $^{126}$ only allows Member States a narrow margin of discretion to restrict the free movement of Union citizens. Member States may restrict the freedom of movement and residence of Union citizens and their family members, irrespective of nationality, on grounds of public policy, public security or public health. These grounds cannot be invoked to serve economic ends. ${ }^{127}$ Measures

\footnotetext{
${ }^{118}$ The ECJ referred to case C-484/93 Svensson and Gustavsson [1995] ECR I-3955, paragraph 15.

119 See Jukka Snell: Freedom to provide Services under the Services Directive compared to the existing case law of the ECJ in Ulla Neergaard, Ruth Nielsen and Lynn Roseberry (eds.): The Services Directive - Consequences for the Welfare State and the European Social Model", Copenhagen 2008.

${ }^{120}$ See T. Tridimas: The General Principles of EU Law. Oxford 2006 p. 209.

${ }^{121}$ The Court's case law on services has embodied the principle of mutual recognition ever since Joined Cases 110 and 111/78 Van Wesemael [1979] ECR 35. The principle was expressed in a particularly strong form in Säger; see further Jukka Snell: Freedom to Provide Services in the Case Law and in The Services Directive: Problems, Solutions, and Institutions in Neergaard, Ulla, Ruth Nielsen and Lynn Roseberry (eds.): The Services Directive - Consequences for the Welfare State and the European Social Model, Copenhagen 2008.

${ }^{122}$ Hans-Wolfgang Micklitz: Judicial Activism of the European Court of Justice and the Development of the European Social Model in Anti-Discrimination and Consumer Law in Ulla Neergaard, Ruth Nielsen and Lynn Roseberry (eds.): The Role of Courts in Developing a European Social Model - Theoretical and Methodological Perspectives, Copenhagen 2010.

${ }^{123}$ Case C-341/05 Laval and Partneri [2007] ECR I-11767.

${ }^{124}$ ECJ Case C-205/07 Gysbrechts [2008] ECR I-9947.

125 2006/123/EC.

126 2004/38/EC.

${ }^{127}$ See Article 27 of the Residence Directive.
} 
taken on grounds of public policy or public security shall comply with the principle of proportionality and shall be based exclusively on the personal conduct of the individual concerned.

\subsection{The Interface between Free Movement and Welfare Rights as Fundamental Rights}

The interface of (national) welfare law and EU law on free movement and fundamental rights is a topical issue. As set out in section 3, there is, on the one hand, a wave of liberalisation and privatisation which is changing the - at least in Denmark - traditional way of setting up labour and welfare rights and the framework of social (distributive) justice. At the same time certain basic fundamental rights, including some social rights and the principle of non-discrimination, are being pursued in the market place, elevating fundamental rights general principles of law binding for both the state and private actors on the market.

In Rutili, ${ }^{128}$ a migrant Italian worker in France was prohibited from residing in four departments in France. It was clear from the file on the case and from information supplied to the ECJ that the reason for the measures taken against him was that his political and trade union activities during 1967 and 1968 were the subject of complaint and that his presence in the departments covered by the decision was for this reason regarded as 'likely to disturb public policy'. The ECJ stated that the concept of public policy used in the then Article 39(3) EC [now Article 45(3) FEU] must, where it is used as a justification for derogating from the fundamental principles of equality of treatment and freedom of movement for workers (emphasis added), be interpreted strictly. Taken as a whole, the limitations placed on the powers of Member States in respect of control of aliens are in the view of the ECJ a specific manifestation of the more general principle, enshrined in Articles 8, 9, 10 and 11 ECHR. ${ }^{129}$ The ECJ thus characterised both the right to free movement and the limitations on free movement rights as expressions of general and fundamental principles.

The ECJ has been confronted with the interface between free movement on the internal market and fundamental rights on a number of occasions and has held that free movement and fundamental rights must be balanced against each other. The one does not automatically take precedence over the other. In Omega Spielhallen, ${ }^{130}$ for example, the ECJ held that the freedom to provide services does not preclude an economic activity from being prohibited on grounds of protecting public policy by reason of the fact that that activity is an affront to human dignity. ${ }^{131}$ In Laval, on the other hand, it held that lawful industrial action under Swedish law was a violation of the then Article 49 EC [now Article 56 FEU] even though the right to take industrial action is a fundamental right under Article 28 of the EU Charter of Fundamental Rights.

In Carpenter ${ }^{132}$ and Festersen, ${ }^{133}$ the ECJ ruled that in situations where a restriction on the free movement at the same time adversely affects the enjoyment of a fundamental right the restriction is to be considered particularly restrictive. The ECJ held in Festersen ${ }^{134}$ that Article 63 FEU (ex

\footnotetext{
${ }^{128}$ Case 36/75 Rutili v Minister of the Interior [1975] ECR 1219.

${ }^{129}$ Article 8 ECHR protects the right to respect for private and family life, Article 9 ECHR the freedom of thought, conscience and religion, Article 10 ECHR the freedom of expression and Article 11ECHR the freedom of assembly and association.

${ }_{130}$ Case C-36/02 Omega Spielhallen- und Automatenaufstellungs-GmbH v Oberbürgermeisterin der Bundesstadt Bonn [2004] ECR I-9609.

${ }^{131}$ See more generally on human dignity in the interpretation of human rights law McCrudden, Christopher: Human Dignity and Judicial Interpretation of Human Rights, European Journal of International Law 2008 p. 655.

${ }^{132}$ Case C-60/00 Carpenter [2002] ECR I-6279.

${ }^{133}$ Case C-370/05 Festersen [2007] ECR I-1129.

${ }^{134}$ Case C-370/05 Festersen [2007] ECR I-1129.
} 
Article 56 EC) on free movement of capital precludes national legislation from laying down as a condition for acquiring an agricultural property the requirement that the acquirer take up his fixed residence on that property for eight years, irrespective of particular circumstances relating to individual characteristics of the agricultural land concerned. It can be accepted that national legislation containing such a requirement, which seeks to avoid the acquisition of agricultural land for purely speculative reasons, and which is thus likely to facilitate the preferential appropriation of that land by persons wishing to farm it, does pursue a public interest objective in a Member State in which agricultural land is a limited natural resource. However, the residence requirement constitutes a measure which goes beyond what is necessary to attain such an objective. First, it turns out to be particularly restrictive in that it restricts not only the free movement of capital but also the right of the acquirer to choose his place of residence freely, guaranteed by the ECHR and protected in the EU legal order, thereby adversely affecting a fundamental right. Nor is there anything to indicate that other measures less restrictive than that requirement could not have been adopted in order to attain the objective pursued. Such a requirement, a fortiori when accompanied by a condition that residence be maintained for several years, goes beyond what could be regarded as necessary.

In identical terms, the ECJ held in Viking ${ }^{135}$ and Laval $^{136}$ that the right to take collective action is a fundamental right which forms an integral part of the general principles of Community law, the compliance of which must be ensured by the ECJ. It referred to Article 28 of the EU Charter of Fundamental Rights ${ }^{137}$ in support hereof. ${ }^{138}$ In both cases the ECJ held that the right to take collective action is a fundamental right under EU law which much be balanced against the right to free movement. It thus dismissed the view that the right to take collective action as a fundamental right is outside the scope of application of the free movement provisions and that the fundamental right for workers to take industrial action always takes precedence over the right of service providers to access to the labour and services markets of other Member States.

The balancing exercise between free movement rights and fundamental rights is governed by the usual justification test for restrictions on free movement, which requires that the restriction must pursue a legitimate aim, and the means applied to achieve the legitimate end (the restriction) must be appropriate and necessary, i.e. the principle of proportionality must be respected; see above in section 4.2. In Viking, the ECJ left the balancing exercise to the national court and only gave some general guidelines while it did the balancing itself in Laval and held that the trade unions had used industrial action in support of wage demands that were too unclear and non-transparent to be accepted as justified. The Laval case is discussed further below in part 6.3. as an example of the clash between free movement rights as access justice at EU level and the use of collective action as a means to ensure minimum wages as part of the national distributive justice system, and in part 7 on fundamental rights.

\footnotetext{
135 Case 438-05, The International Transport Workers' Federation and The Finnish Seamen's Union ECR 2007 I-10779.

${ }^{136}$ Case C-341/05 Laval un Partneri [2007] ECR I-11767.

${ }^{137}$ Article 28 on the Right of collective bargaining and action reads: 'Workers and employers, or their respective organisations, have, in accordance with Community law and national laws and practices, the right to negotiate and conclude collective agreements at the appropriate levels and, in cases of conflicts of interest, to take collective action to defend their interests, including strike action'.

${ }^{138}$ See paragraph 43 in Viking and paragraph 90 in Laval.
} 
One may ask if the coming into force of the Lisbon Treaty as of 1 December 2009 has changed the balance between market freedoms and fundamental rights. ${ }^{139}$ By and large we think the answer is no, but the Member States' possibilities for justifying a restriction on free movement are more limited if the restriction both limits the right to free movement and a fundamental right. The Charter's binding effect since 1 December 2009 therefore limits the discretion of the Member States to justify restrictions under the Cassis de Dijon case law of the ECJ.

In his contribution ${ }^{140}$ to the Blurring Boundaries project, Hans Micklitz argues for the following hypothesis:

1. The ECJ is developing, on the basis of the acquis communautaire, a European Social Framework, not a fully-fledged European Social Model.

2. The ECJ's Social Model is based on access justice, not on social justice.

3. More recently, the ECJ tends to substitute national social models with its own European Social Model.

We will comment on it generally in this section and come back to aspects of it below in sections 5 and 6. In our view it is not very important whether the European Social Model is called a model or a framework. ${ }^{141}$ Micklitz' finding that the ECJ's version of a European Social Model is based on access justice, not on distributive ${ }^{142}$ justice is, in our view, true and very important for understanding the interplay between EU and national welfare law in the multi-level legal system that the mutually embedded EU and national welfare law systems constitute.

\subsection{Services Directive}

The first conference within the framework of the Blurring Boundaries project in 2007 focused on the Services Directive ${ }^{143}$ and its importance for answering the research questions outlined above in

\footnotetext{
${ }^{139}$ See generally on this balance Stefano Giubboni: Social Rights and market Freedoms. A Labour Law Perspective, Cambridge 2006. See in regard to the Blurring Boundaries project Ruth Nielsen: The Charter of Fundamental Rights and Migrant Workers' Welfare Rights in Ulla Neergaard, Ruth Nielsen and Lynn Roseberry (eds.): Integrating Welfare Functions into EU Law - From Rome to Lisbon, Copenhagen 2009.

${ }^{140}$ See Hans-W. Micklitz: Judicial Activism of the European Court of Justice and the Development of the European Social Model in Anti-Discrimination and Consumer Law in Ulla Neergaard, Ruth Nielsen and Lynn Roseberry (eds.): The Role of Courts in Developing a European Social Model - Theoretical and Methodological Perspectives, Copenhagen 2010.

${ }^{141}$ As appears from the quotation, Micklitz shifts terminology from part 1 to part 3 in his hypothesis.

${ }^{142}$ We use the term social justice as by and large the same as distributive justice, cf. Study Group on Social Justice in European Private Law: Social Justice in European Contract Law: a Manifesto, European Law Journal 2004 p. 653 which states (emphasis added): 'First, at bottom, there is the issue of fairness or social justice. The chosen market order has to embrace and protect a distributive pattern of outcomes that ensures fair treatment for every European citizen, and guarantees that the rules of the market system do not permit exploitation and social exclusion. Second, this scheme of distributive justice must align itself with the basic constitutional principles that establish and protect the rights of citizens. The market order does not merely shape the distribution of material wealth, but also has ramifications for the ability of citizens to enjoy and benefit from their acknowledged civil liberties and social and economic rights. The rules of European contract law that govern the fundamentals of the market order need to fit into a coherent pattern with those acknowledged fundamental rights. Third, these principles of social justice must acquire their legitimacy both through the process by which they are selected and how they are maintained. As these principles evolve through further legislation, judicial decision, and other modes of norm creation, the process has to secure legitimacy for its outcomes through democratic participation and dialogue. Fourth, these principles of social justice must discover a way to reconcile the ambition of creating an ever closer union of the peoples of Europe based upon common values with the need to respect their diversity and differences.'

143 2006/123/EC. See Ulla Neergaard, Ruth Nielsen and Lynn Roseberry (eds.): The Services Directive - Consequences for the Welfare State and the European Social Model", Copenhagen 2008 and Davies, Gareth: Legislative Comment. The Services Directive: Extending the Country of Origin Principle, and Reforming Public Administration, European Law Review 2007 p. 232.
} 
the Introduction. ${ }^{144}$ The conference resulted in the book: The Services Directive - Consequences for the Welfare State and the European Social Model. ${ }^{145}$ The essays in this book indicate that the Services Directive is yet another contribution to the blurred line between state and market. There are seven contributions altogether, each of which addresses different dimensions of the Services Directive, including the consequences for the welfare state and the European Social Model. Dagmar Schiek's essay introduces the European Social Model from a more general point of view, whereas Ulla Neergaard analyses the welfare services named "services of general (economic) interest”. Lynn Roseberry focuses on the general principle of non-discrimination. Elisabetta Bergamini, Jukka Snell and Ruth Nielsen address the more operational chapters of the Services Directive as they focus on the freedom of establishment, the freedom to provide services and the rights of recipients of services respectively. Finally, Frank Hendrickx addresses the issue of social dumping.

An important legal change resulting from the Services Directive (for services that are fully within its scope) is that the ban on restrictions on free movement laid down in Article 56 FEU (ex Article 49 EC) as interpreted by the ECJ is made more stringent by Article 16 of the Services Directive, which only allows justification of restrictions by reference to public policy, public security, public health or protection of the environment ${ }^{146}$, as opposed to Article 56 FEU, which allows justification by reference to all the overriding reasons relating to the public interest that are accepted in the case law of the ECJ. The Services Directive contains two different provisions on justification of restrictions: one ${ }^{147}$ on restrictions to the freedom of establishment and one ${ }^{148}$ on restrictions imposed upon a service provider. The provision on justification of restrictions upon the freedom of establishment reads:

Member States shall verify that the requirements referred to in paragraph 2 satisfy the following conditions:

(b) necessity: requirements must be justified by an overriding reason relating to the public interest;

With regard to restrictions imposed upon a service provider, the justification provision in the Services Directive reads:

(b) necessity: the requirement must be justified for reasons of public policy, public security, public health or the protection of the environment;

The latter provision on justification of restrictions imposed upon service providers is narrower than the one applying to restrictions on the freedom of establishment where necessity is justification 'by an overriding reason relating to the public interest' (defined by reference to ECJ case law, and

\footnotetext{
144 See generally on the Services Directive Catherine Barnard: Unravelling the services Directive, Common Market Law Review 2008 p. 323.

${ }^{145}$ Neergaard, Ulla, Ruth Nielsen and Lynn Roseberry (eds.): The Services Directive - Consequences for the Welfare State and the European Social Model, Copenhagen 2008.

${ }^{146}$ See Article 16(1)(b) and 16(3) of the Services Directive.

${ }^{147}$ See Article 15(3)(b).

${ }^{148}$ See Article 16(1).
} 
including 'the protection of consumers') and narrower than Article 56 FEU as interpreted by the ECJ. ${ }^{149}$

\subsection{Preliminary Conclusions}

It is clear from the ECJ's case law that welfare law-related discriminations and/or restrictions are not outside the scope of application of EU free movement law. That also applies when the welfare aspects at issue can be regarded as fundamental rights. Welfare rights must be balanced against the right to free movement; see below in section 7 on balancing of constitutional rights. This balancing exercise must be undertaken on a case by case basis.

In our view, the rules on migrant workers covered by Article 45 FEU do not tip the balance between free movement and fundamental rights to the detriment of fundamental rights. It may, however, be different in respect of workers posted by employers exercising their right of freedom to provide services under Article 56 FEU. ${ }^{150}$ Article 45 FEU does not apply to such workers. ${ }^{151}$

Recent judgments on posted workers such as Laval, Rüffert ${ }^{152}$ and Commission v Luxembourg $^{153}$ have been much criticised for setting aside collective agreements and workers' rights in favour of free movement. ${ }^{154}$

The binding force which the Charter of fundamental rights of the European Union acquired on 1 December 2009 will probably not generally change this situation, but the Member States' possibilities for justifying a restriction on free movement is more limited if the restriction both limits the right to free movement and a fundamental right. In Festersen, ${ }^{155}$ the ECJ stated that if a restriction (in that case a residence requirement which restricted the free movement of capital) adversely affects a fundamental right guaranteed by the ECHR, it is to be considered particularly restrictive. Since the Charter - as of 1 December 2009 - became legally binding, it has therefore limited the discretion of the Member States to justify restrictions under the Cassis de Dijon case law of the ECJ.

\section{EU Constraints upon National Welfare Standards through Harmonisation}

There has been tension between the goal of the harmonisation of social policy and the free-market aims of European integration since the beginning of the EU/EC in the mid $20^{\text {th }}$ century. ${ }^{156}$ On the one hand, the Treaty of Rome left virtually all matters relating to labour legislation and welfare

\footnotetext{
${ }^{149}$ See for the same interpretation Jukka Snell's article Freedom to Provide Services in the Case Law and in the Services Directive: Problems, Solutions, and Institutions in Neergaard, Ulla, Ruth Nielsen and Lynn Roseberry (eds.): The Services Directive Consequences for the Welfare State and the European Social Model, Copenhagen 2008 at note 87.

${ }^{150}$ See for a similar view Herwig Verschueren: Cross-Border Workers in the European Internal Market. Trojan Horses for Member States Labour and Social Security Law, International Journal of Comparative Labour Law and Industrial Relations, 2008) p. 167.

${ }^{151}$ See case C-49/98 Finalarte [2001] ECR I-7831.

152 Case C-346/06 [2008] ECR I-0000 (not yet reported).

${ }^{153}$ Case C-319/06 [2008] ECR I-0000 (not yet reported).

${ }^{154}$ See on these judgments Ruth Nielsen: Udstationering af arbejdstagere som led i udveksling af tjenesteydelser - Viking-, Laval- og Rüffert-sagerne, Arbeidsrett 2008 p. 61, Ronnie Eklund: A Swedish Perspective on Laval, Comparative Labor Law and Policy Journal 2008 p. 551 and for an article that argues for the right to benefit from the competitive advantage access to cheap labour gives, see Norbert Reich: Free Movement v. Social Rights in an Enlarged

Union - the Laval and Viking Cases before the ECJ, German Law Journal 2008 p 125, http://www.germanlawjournal. $\mathrm{com} /$.

${ }^{155}$ Case C-370/05 Festersen [2007] ECR-1129.

${ }^{156}$ See Catherine Barnard and Simon Deakin: 'Negative' and 'Positive' Harmonization of Labor Law in the European Union, Columbia Journal of European Law 2002 p. 389.
} 
state expenditure levels within the competence of the individual Member States. Free movement of goods, capital and workers, freedom of establishment, and freedom to supply services were, on the other hand, guaranteed by core Treaty provisions.

Over the years, a considerable harmonisation of welfare law has taken place. Beginning with the Single European Act in 1986, the EU has been given some additional powers to adopt social policy measures. ${ }^{157}$ The Protocol and Agreement on Social Policy that was added to the EC Treaty by the Maastricht Treaty of 1991 allowed all the Member States that were parties to the Social Policy Agreement to adopt policies on employment and industrial relations. ${ }^{158}$ This addition provided the basis for adoption of labour law directives. The Treaty of Amsterdam of June 1997 deleted the Protocol providing for the UK's opt-out from the Agreement on Social Policy and incorporated the latter into a revised 'Social Chapter' of the EC Treaty. The (then) new Social Chapter of the EC Treaty, as amended by the Treaties of Amsterdam and Nice, extended EU competences in the field of employment and industrial relations, obliged the Commission to consult management and labour in the formulation of EU law in the field of social policy, formally established a role for management and labour in the legislative process of the EU (including the making of binding agreements at EU level), and allowed for qualified majority voting on legislative proposals before the Council of Ministers, in broad areas of employment and industrial relations. Nevertheless, the expanding treaty basis for EU legislation on social policy has not fundamentally changed the fact that responsibility for core welfare issues - collective labour law, social security, health care, public education - is still allocated to the Member States. ${ }^{159}$ Furthermore, there is no binding legal instrument at EU level that spells out to what extent EU law may interfere with the Member States' social policy decisions, nor what the guiding principles for such interference should be. In the absence of explicit guidance in the Treaty, it has been left to the ECJ to monitor the relationship between EU law and issues normally considered as belonging within the realm of national social policy as demonstrated in the Laval judgment. ${ }^{160}$

As mentioned in part 1, binding EU law constraints on National Welfare Standards can be found in Treaty provisions (including the Charter of Fundamental Rights of the EU), ECJ case law and secondary law, primarily in the form of harmonising directives. In the Blurring Boundaries project we have not looked in detail at the substantive content of secondary law (the harmonisation directives and soft law measures) but have focused on EU primary law.

The degree to which harmonisation puts constraints upon the Danish welfare state or contributes to ensuring welfare rights at EU level depends on whether or not the EU has any competence, and if so whether the EU competence is exclusive competence under Article 3 FEU, shared competence under Article 4 FEU, coordinative competence under Article 5 FEU or only competence to support Member States' actions under Article 6 FEU; whether or not a Member State (for example Denmark) can block the adoption of the measure at issue in Council, i.e. whether unanimity or

\footnotetext{
157 The Single European Act 1986 introduced majority voting (Article 118a) to adopt minimum requirements with a view to "encouraging improvements, especially in the working environment, as regards the health and safety of workers". It also provided a provision, Article 118b EC, authorising the Commission to develop dialogue between management and labour at European level.

158 The only Member State to opt out was the UK.

159 See Damjanovic, Draga and De Witte, Bruno: Welfare Integration through EU Law: The Overall Picture in the Light of the Lisbon Treaty”, in Neergard, Ulla, Nielsen, Ruth, and Roseberry, Lynn (eds.): Integrating Welfare Functions into EU Law: From Rome to Lisbon, Copenhagen 2009.

${ }^{160}$ Case C-341/05 Laval [2007] ECR I-1767.
} 
qualified majority voting apply; and whether the harmonisation at issue is minimum harmonisation or full harmonisation.

\subsection{EU Competence in Regard to Welfare Law: the Principle of Conferral}

As stated in Article 5 EU, the limits of EU competences are governed by the principle of conferral. Under that principle, the Union shall act only within the limits of the competences conferred upon it by the Member States in the Treaties to attain the objectives set out therein. Competences not conferred upon the EU in the Treaties remain with the Member States. Direct taxation is for example still under Member States' competence, but they must respect EU primary law on free movement on the internal market when they exercise their legislative competence in tax law; see below in section 6.2.1 on the limitation of Member States' discretion in regard to tax revenue.

The EU is thus only competent to adopt measures if it has been given competence to do so in the Treaties. EU Competence can be exclusive, joint with national governments, or supporting, with national governments having lead competence. Part One Title I of the FEU Treaty sets out the categories and areas of EU competence. It distinguishes between exclusive competence for the EU (Article $3 \mathrm{FEU}$ ), shared competence between the EU and its Member States (Article 4 FEU), coordination measures for economic, employment and social policies (Article $5 \mathrm{FEU}$ ) and competence for the EU to support, coordinate or supplement the actions of the Member States (Article 6 FEU).

Most EU legal acts related to welfare law have their legal base in provisions in the areas in which the EU and its Member States according to Article 4 FEU have shared competence or fall within the areas where the EU only ensures coordination or complementation of the actions of the Member States. Shared competence between the EU and the Member States applies in the following areas: internal market; social policy, for the aspects defined in the FEU Treaty; economic, social and territorial cohesion; agriculture and fisheries, excluding the conservation of marine biological resources; environment; consumer protection; transport; trans-European networks; energy; area of freedom, security and justice; and common safety concerns in public health matters, for the aspects defined in the FEU Treaty.

Under Article $5 \mathrm{FEU}$, the Council of the EU shall adopt measures, in particular broad guidelines for the economic policies of the Member States and shall take measures to ensure coordination of the employment policies of the Member States, in particular by defining guidelines for these policies. In addition, the EU may take initiatives to ensure coordination of Member States' social policies.

Under Article $6 \mathrm{FEU}$, the EU has competence to carry out actions to support, coordinate or supplement the actions of the Member States. The areas of such action, at European level, are: protection and improvement of human health; industry; culture; tourism; education, vocational training, youth and sport; civil protection; and administrative cooperation.

Article 3 FEU lists the areas where the EU has exclusive competence. ${ }^{161}$ The EU does not have exclusive competence in core welfare areas. In the Blurring Boundaries project we do, however, use

\footnotetext{
${ }^{161}$ I.e. (a) customs union; (b) the establishing of the competition rules necessary for the functioning of the internal market; (c) monetary policy for the Member States whose currency is the euro; (d) the conservation of marine biological resources under the common fisheries policy; (e) common commercial policy and the conclusion of an international agreement when its conclusion is
} 
the terms 'welfare functions', 'welfare services', and 'welfare rights' as such broad concepts cutting across various legal disciplines (EU constitutional law, human rights law, competition law, labour law, social security law, etc.) that even areas governed by exclusive EU competence may be relevant to welfare law.

\subsection{From Unanimity to Qualified Majority Voting in Council}

The voting procedure of the Council of the European Union currently (2010) operates on a system laid down by the Treaty of Nice. The Treaty of Lisbon replaces the system, but only from 2014 . Under Article 16(3) EU, the Council shall act by a qualified majority except where the Treaties provide otherwise. When the ordinary legislative procedure defined in Article 294 FEU is used, legal acts are thus adopted by qualified majority voting in Council. As from 1 November 2014, a qualified majority shall be defined as at least $55 \%$ of the members of the Council, comprising at least fifteen of them and representing Member States comprising at least $65 \%$ of the population of the Union. A blocking minority must include at least four Council members, failing which the qualified majority shall be deemed attained. ${ }^{162}$ The Treaty of Lisbon generally extends the areas where decisions can be taken by qualified majority in comparison to the Treaty of Nice. Of relevance to welfare law, it may be noticed that that for example is the case in regard to services of general economic interest (Article 14 FEU, ex Article 16 EC) and social security (Article 48 FEU, ex Article 42 EC).

\subsection{From Minimum Harmonisation to Full Harmonisation?}

In the specific legal basis for directives on various subjects there are more precise rules on whether or not full harmonisation measures or only minimum harmonisation may be adopted. Most of the areas with shared competence are welfare-relevant. In some of these areas the EU has competence to adopt full harmonisation. That is notably the case as far as the internal market is concerned; see Article 114 FEU. In such areas, it can choose not to use its full competence and limit the directives adopted to setting minimum requirements. In other areas, for example social policy and labour law measures adopted under Article 153 FEU, the EU only has competence to adopt minimum harmonisation.

Minimum harmonisation takes away the freedom of a Member State to set a lower level than the EU minimum level. In regard to welfare rights in Denmark, minimum harmonisation has forced Denmark to raise the level of protection against discrimination; see below in section 7. Full harmonisation detracts more competences from the Member States by also setting a ceiling over welfare services. One may therefore ask to what extent welfare areas are already fully harmonised and in which areas EU rules pre-empt the Member States from maintaining or introducing stricter standards. It is important for the degree to which EU law potentially lowers the national welfare standard to what extent competence to adopt full harmonisation directives in welfare areas has been conferred upon the EU, and when such competence has been conferred whether the Council must act unanimously or can take decisions by qualified majority; see above in section 5.2.

provided for in a legislative act of the Union or is necessary to enable the Union to exercise its internal competence, or in so far as its conclusion may affect common rules or alter their scope.

162 See Article 16(4) EU. The other arrangements governing the qualified majority are laid down in Article 238(2) FEU. 
If one compares the law as it was at the inception of the EU in 1957 and as it is after the coming into force of the Lisbon Treaty as of 1 December 2009, there is a general trend in EU law from minimum harmonisation towards full harmonisation and from unanimous decision-making in Council towards decision-making by qualified majority and towards sharing the legislative competence at EU level between the Council and the European parliament.

In consumer law there seems to be a trend towards full harmonisation, whereas in core welfare areas, the EU still only has competence to adopt minimum harmonisation measures. In regard to consumer law, Article 169 FEU provides that in order to promote the interests of consumers and to ensure a high level of consumer protection, the Union shall contribute to protecting the health, safety and economic interests of consumers, as well as to promoting their right to information, education and to organise themselves in order to safeguard their interests. The Union shall contribute to the attainment of these objectives through either:

(a) measures adopted pursuant to Article 114 FEU in the context of the completion of the internal market; or

(b) measures which support, supplement and monitor the policy pursued by the Member States.

The EU has competence to full harmonisation in Article 169 (a) FEU when consumer law is regulated as an aspect of the internal market but only to minimum harmonisation when measures are taken under Article 169 (b) FEU.

The EU consumer law directives from the 1980's and 1990's ${ }^{163}$ only provided for minimum harmonisation and left the Member States the option of choosing a higher standard. The Scandinavian countries made use of this opportunity and usually regard themselves as countries with a high level of consumer protection. In Buet, ${ }^{164}$ di Pinto ${ }^{165}$ and Doc Morris, ${ }^{166}$ the ECJ confirmed that the minimum harmonisation principle grants the Member States leeway and discretion in maintaining or establishing a higher level of protection in matters of consumer law. In the Communication from the Commission to the European Parliament, the Council, the Economic and Social Committee and the Committee of the Regions on a consumer policy strategy 2002-2006, the Commission signalled a change in strategy. It now favoured full harmonisation; see the following (emphasis added): ${ }^{167}$

\footnotetext{
“The Green Paper on Consumer Protection (COM 2001531 final) set out options for the further harmonisation of rules on commercial practices, either on a case-by-case basis or supplementing this through framework legislation. There is also a need to review and reform existing EU consumer protection directives, to bring them up to date and progressively adapt them from minimum harmonisation to 'full harmonisation' measures.
}

In his contribution ${ }^{168}$ to the Blurring Boundaries project, Hans Micklitz, as mentioned above in section 4, argues that the ECJ interprets primary law on free movement and the principle of proportionality in a way that transforms minimum directives into maximum directives and cites, in

\footnotetext{
${ }^{163}$ For example the Directive on Unfair Contract Terms 93/13/EEC.

${ }^{164}$ ECJ, Case C-382/87 1989 ECR I-1235.

165 ECJ, 14.3.1991 Case C-361/89 1991 ECR I-1189.

${ }^{166}$ ECJ, Case C- 322/01 Doc Morris I-14887, 15008.

${ }^{167}$ OJ C 137, 8.6.2002, 2.

${ }^{168}$ See Hans-W. Micklitz: Judicial Activism of the European Court of Justice and the Development of the European Social Model in Anti-Discrimination and Consumer Law in Ulla Neergaard, Ruth Nielsen and Lynn Roseberry (eds.): The Role of Courts in Developing a European Social Model - Theoretical and Methodological Perspectives, Copenhagen 2010.
} 
particular, the judgments in Gysbrechts ${ }^{169}$ and Laval in favour of his interpretation; see on Laval above in section 4.3.

In Gysbrechts the questions referred to the ECJ were about free movement of goods and consumer protection in connection with distance selling. Article 6 of the Distance Selling Directive $^{170}$ lays down minimum requirements on consumer protection. Belgian law gave more consumer protection than this minimum standard by prohibiting. A Belgian company offered goods for sale via an internet site. In respect of buyers from other countries than Belgium, the only acceptable means of payment was credit card. When a payment was to be made by credit card, the customer had to state on the order form the number and validity period of the card. That violated the Belgium law. The problem before the ECJ was whether such a higher level of consumer protection than the minimum required by the Directive. The ECJ held that the higher Belgian protection standards, which reached beyond the EU minimum, violated the principle of proportionality.

In matters of gender equality in occupation and employment, the EU has - assessed by the wording of the legal base - in principle competence under Article 157(3) FEU to adopt both minimum and full harmonisation. ${ }^{171}$ So far all the gender equality directives have contained clauses that allow the Member States to go further in the direction of equality. ${ }^{172}$ Under Article 19 FEU there is also - assessed by the wording of that provision - competence to adopt both minimum and full harmonisation in order to combat discrimination based on sex, racial or ethnic origin, religion or belief, disability, age or sexual orientation. Directives based on this legal base have so far also contained clauses to the effect that the directives only contain minimum requirements. ${ }^{173}$ In discrimination law, the EU has thus left the Member States free to set a higher standard of equality than the minimum required by EU law even though it, under the present FEU Treaty - assessed by the wording of the text of the Treaty - would be possible for the EU to adopt full harmonisation.

In our view, it does, however, follow from the fundamental human rights character of the prohibition against discrimination and the constitutional context that the Member States are free to choose a higher standard of protection than the one chosen in EU law. In favour of this interpretation, the Deutsche Telekom-cases ${ }^{174}$ on equal pay may be invoked. These cases were about violations by a German employer (Deutsche Telekom) of the equal pay principle by excluding German part-time workers from pension schemes. Because most part-time workers are women, such exclusion is indirect sex discrimination in violation of the equal pay rules in both EU law and national German law. The German rules apply to periods from the coming into force of the

\footnotetext{
${ }^{169}$ ECJ Case C-205/07 Gysbrechts [2008] ECR I-9947.

170 97/7/EC.

${ }^{171}$ Article 157(3) provides: The European Parliament and the Council, acting in accordance with the ordinary legislative procedure, and after consulting the Economic and Social Committee, shall adopt measures to ensure the application of the principle of equal opportunities and equal treatment of men and women in matters of employment and occupation, including the principle of equal pay for equal work or work of equal value.

172 See Article 7 in the Gender Equality Goods and Services Directive 2004/113/EC and Article 27 in the Recast Directive 2006/54/EC.

${ }^{173}$ Article 6 of the Ethnic Equality Directive 2000/43/EC provides: 1. Member States may introduce or maintain provisions which are more favourable to the protection of the principle of equal treatment than those laid down in this Directive. 2. The implementation of this Directive shall under no circumstances constitute grounds for a reduction in the level of protection against discrimination already afforded by Member States in the fields covered by this Directive.

Article 7 of Directive 2004/113/EC of 13 December 2004 implementing the principle of equal treatment between men and women in the access to and supply of goods and services contains a similar provision on minimum requirements.

${ }^{174}$ Case C-50/96 Schröder [2000] ECR I-743, case C-270/97 Sievers [2000] ECR I-929 and joined case C-234/96 and C-235/96 Vick et al [2000] ECR I-799.
} 
German Grundgesetz in 1949. Article 157 FEU (ext art. 119 EC and 141 EC) is only directly applicable against employers in regard to equal pay in periods after 8 April 1976; see Defrenne II. ${ }^{175}$ In Barber, ${ }^{176}$ a special time limitation at 17 May 1990 was fixed for pension matters. German law was thus more favourable for discriminated women than EU law. The workers in the Deutsche Telekom cases claimed equal pay for periods for which they had such a claim under German law but not under EU law. The employer Deutsche Telekom asserted that EU law on equal pay - Article 157 FEU - should be interpreted as a maximum provision in order to protect German employers from being treated by stricter standards than employers in other EU countries. Deutsche Telekom did therefore not accept that it should respect the equal pay principle in pension matters for periods before 17 May 1990.

The ECJ held that Article 157 FEU [then Article 119 EC] does not preclude provisions of a Member State which lay down a principle of equal treatment by virtue of which part-time workers are entitled to retroactive membership of an occupational pension scheme and to receive a pension under that scheme, notwithstanding the risk of distortions of competition between economic operators of the various Member States to the detriment of employers established in the first Member State. The application of national law cannot be held to be contrary to the principle of nondiscrimination on grounds of nationality merely because other Member States allegedly apply less strict rules. Moreover, the economic aim pursued by Article 157 FEU [then Article 119 EC], namely the elimination of distortions of competition between undertakings established in different Member States, is secondary to its social aim, which constitutes the expression of a fundamental human right not to be discriminated against on grounds of sex.

As is well known, the EU protection of fundamental rights has been developed in dialogue with the highest national courts partly as a means to ensure their acceptance of the supremacy of EU law over national law. The German Bundesverfassungsgericht has only accepted that EU law takes precedence over German law as long as (So-lange) EU law protects fundamental rights as well as German law does. If EU law on equality and discrimination was interpreted as setting a maximum, the pre-conditions for Germany's acceptance of the supremacy of EU law would no longer be fulfilled. It is therefore not likely that the ECJ will interpret EU equality and anti-discrimination provisions as maximum rules.

\subsection{Preliminary Conclusions}

Minimum harmonisation takes away the freedom of a Member State to set a lower level than the EU minimum level. For Denmark that has had practical importance in regard to non-discrimination law; see below in section 7 .

Full harmonisation detracts more competences from the Member States by also setting a ceiling over welfare services. In many welfare relevant areas, the EU only has competence to minimum harmonisation. In consumer law and in regard to services of general economic interest, the EU has, however, competence to full harmonisation.

\footnotetext{
${ }^{175}$ Case 43/75 Defrenne II [1976] ECR 455.

${ }^{176}$ Case 262/88 Barber [1990] ECR I-1889.
} 
6 Undermining the Solidarity behind the National Welfare States. Market Access Justice at EU Level and Distributive Justice at National Level

In Denmark, tax-financing of a number of welfare services and cash benefits and the collective labour law system for fixing minimum wages (including the right of trade unions to take collective action which might hinder the free movement of service providers and employers) are key elements of the Danish distributive justice system. ${ }^{177}$ EU law on free movement limits the options of Member States to arrange their tax law as they wish, and it can make a welfare state of the Danish kind either more costly or more limited because either rights have to be given to everyone irrespective of nationality including those who exercise free movement rights under EU law or alternatively to no one. That provides an argument for dismantling part of the welfare state, i.e. choose to give welfare rights to no one or more limited rights to everyone.

As set out above in section 4, solidarity plays an important role in the definition of the scope of competition law. ${ }^{178}$ The access rights provided for by EU internal market law cover both rights for citizens in another EU country to move into an EU Member State and rights for EU citizens to move out of one's own Member State to take advantage of the free movement rules in another EU country, for example as a recipient of health services, and claim re-imbursement of certain welfarerelated expenses from one's own Member State.

\subsection{Expansion of Welfare Services and Welfare Rights to Cover EU Migrants and (some) Third Country Nationals as a Matter of EU Law}

All aspects of free movement of goods, services, capital, freedom of establishment and free movement of persons affect the degree to which Member States have discretion to choose what kind of welfare state and welfare law they wish. In order to uphold a welfare state of the Danish type, it is necessary for the Danish state to be able to get money from taxation and to avoid abuse by social tourists who want to take advantage of the fairly generous benefits and services in the Danish welfare state without having a 'real link' to Denmark and to prevent social dumping which could undermine Danish minimum wages. The ECJ has developed a considerable case law on 'real links' between migrants and host society. ${ }^{179}$ The closer the bond between the individual claimant and the Member State, the more secure will be the claimant's right to reside within the territory, free from the fear of expulsion on economic or financial grounds; ${ }^{180}$ and the more extensive his/her right to equal treatment within the host society, as regards welfare and other social benefits. ${ }^{181}$

\footnotetext{
${ }^{177}$ For a fuller description and analysis of the solidarity underlying the Danish welfare state, see Ulla Neergaard: In Search of the Role of 'Solidarity' in Primary Law and the Case Law of the European Court of Justice in Ulla Neergaard, Ruth Nielsen and Lynn Roseberry (eds.): The Role of Courts in Developing a European Social Model - Theoretical and Methodological Perspectives, Copenhagen 2010.

${ }^{178}$ For more details, see Krajewski, Markus, Neergaard, Ulla B. and Van de Gronden, Johan (eds.): The changing legal framework for services of general interest in Europe: Between competition and solidarity, The Hague 2009 and Nina Boeger: Solidarity and EC Competition Law, European Law Review 2007, p. 319.

${ }^{179}$ The concept was first employed by the ECJ in Case C-224/98 D’Hoop [2002] ECR I-6191.

${ }^{180}$ E.g. Case C-184/99 Grzelczyk [2001] ECR I-6193; Case C-413/99 Baumbast [2002] ECR I-7091; Case C-456/02 Trojani [2004] ECR I-7573.

${ }^{181}$ E.g. Case C-85/96 María Martínez Sala [1998] ECR I-2691; Case C-184/99 Grzelczyk [2001] ECR I-6193; Case C-224/98 D’Hoop [2002] ECR I-6191; Case C-138/02 Collins [2004] ECR I-2703; Case C-209/03 Bidar [2005] ECR I-2119; Case C-258/04 Ioannidis [2005] ECR I-8275; Case C-456/02 Trojani [2004] ECR I-7573. See the discussion by Michael Dougan and Eleanor Spaventa, "Wish You Weren't Here... New Models of Social Solidarity in the European Union” in Michael Dougan and Eleanor Spaventa (eds.): Social Welfare and EU Law, Oxford, 2005. Michael Dougan: The Spatial Restructuring of National Welfare States within the European Union: the Contribution of Union Citizenship and the Relevance of the Treaty of Lisbon in Ulla Neergaard, Ruth Nielsen and Lynn Roseberry (eds.): Integrating Welfare Functions into EU Law - From Rome to Lisbon, Copenhagen 2009.
} 
The right to free movement for persons, in particular workers (Article 45 FEU) and Union citizens (Article $21 \mathrm{FEU}$ ), includes certain rights to receive welfare services from the host country in order to prevent obstacles to their free movement. Some aspects of social security for migrant workers are dealt with in detail in Regulation 883/04. ${ }^{182}$ Regulation 1612/68 on freedom of movement for workers contains a provision in Article 7(2) requiring equal treatment of EU migrant workers as compared with workers with host country nationality with regard to tax and social advantages. The ECJ has interpreted both the concepts of 'workers' and 'social advantages' so broadly that Regulation 1612/68 covers not only what would be considered within the scope of employment law, but also a number of (other) welfare services. In addition to the specific welfare aspects covered by the above Regulations, the ECJ's case law on European citizens and migrant workers establishes some welfare rights. The Residence Directive ${ }^{183}$ grants social rights to family members of migrant EU citizens irrespective of the nationality of the family member.

\subsection{The Tension between Market Access Justice at EU Level and Distributive Justice at National Level in Regard to Tax-financed Services and Benefits}

\subsubsection{Limitation of Member States' Discretion in Regard to Tax Revenue}

Direct taxation is still mainly a matter to be decided by national law, but the Member States must respect all the EU free movement provisions. Article 65 FEU (ex Article 58 EC) does, however, provide that the provisions of Article $63 \mathrm{FEU}$ on the free movement of capital shall be without prejudice to the right of Member States to apply the relevant provisions of their tax law which distinguish between taxpayers who are not in the same situation with regard to their place of residence or with regard to the place where their capital is invested. Such measures and procedures must not constitute a means of arbitrary discrimination or a disguised restriction on the free movement of capital and payments as defined in Article 63 FEU. There have been a number of cases about national tax law as a possible restriction to free movement. O’Brien states that: ${ }^{184}$

The gradual narrowing of Member State tax policy options through legislation, litigation, and state aid enforcement means it is increasingly difficult for Member States to maintain a national tax system, including a network of bilateral tax conventions with other Member States, which reflects national economic and social policy objectives and which provides predictable revenue and expenditures.

In an infringement case against Denmark, ${ }^{185}$ the ECJ declared that, by introducing and maintaining in force a system for life assurance and pensions under which tax deductions and tax exemptions for payments are granted only for payments under contracts entered into with pension institutions established in Denmark, whereas no such tax relief is granted for payments made under contracts entered into with pension institutions established in other Member States, Denmark had failed to fulfil its obligations under Articles 45 FEU (ex Article 39 EC) on free movement of workers, Article 49 FEU (ex Article 43 EC) on freedom of establishment and Article 56 FEU (ex Article 49 EC) on free movement of services.

\footnotetext{
${ }^{182}$ Which, on 1 May 2010, replaced Regulation 1401/71.

183 2004/38/EC.

${ }^{184}$ O’Brien, Martha: Company Taxation, State Aid and Fundamental Freedoms: Is the Next Step Enhanced Cooperation?, European Law Review 2005 p. 209.

${ }^{185}$ Case C-150/04 Commission v Kingdom of Denmark [2007] ECR I-1163.
} 


\subsubsection{Limitation of Member States' Discretion in Regard to Social Expenditure}

In his contribution to the Blurring Boundaries project, Michael Dougan ${ }^{186}$ explores the contribution of Union citizenship to the emergence of a 'European welfare space', characterised by the continued pre-eminence of national systems of social solidarity, but complemented by novel subnational and supranational dimensions to individual welfare rights and expectations. In particular, he explores the case law of the ECJ on the residency, equal treatment and movement rights of migrant Union citizens vis-à-vis their host and home states, highlighting the two main bodies of academic criticism prompted by that case law. First, the allegation of social engineering, i.e. that EU law is interfering in a top-down fashion with complex national welfare processes, so as to promote an understanding of social solidarity at odds with the traditional relationship between individual rights and collective interests. Secondly, the allegation of judicial activism, i.e. that the welfare rights and obligations associated with Union citizenship have been forged by the ECJ, despite the limited regulatory competences conferred upon the EU by the Treaty, and sometimes even in the face of the legislative choices expressed by the Union's accountable political institutions.

Denmark may be mentioned as an example of a Member State with a traditional high level of welfare state protection which has limited access for both Danish citizens and other EU citizens to welfare services and benefits to avoid a politically undesirable extensive use of the Danish welfare system by foreigners. As an example, parental leave legislation may be mentioned; see in particular an Act $^{187}$ from 2004 adopted as a means to adapt Danish welfare legislation to the then upcoming Eastern enlargement of the EU. In the preparatory works there is explicit reference to fears of expected excessive use by Eastern European workers.

\subsection{The Tension between Market Access Justice and Distributive Justice Related to Minimum Wages: the Laval Case}

Seen from a Nordic perspective, the single most controversial ECJ judgment in the social field is Laval. ${ }^{188}$ Laval illustrates the clash between a European Social Model based on access justice at EU level and national welfare states with highly developed distributive justice systems at national level. In the Laval case, the part of the national distributive justice system that is at issue is the way minimum wages are fixed in the Nordic countries through collective agreements.

Generally, the Posting of Workers Directive ${ }^{189}$ is somewhat unclear, and its extent has been subject to debate. ${ }^{190}$ Recent judgments on posted workers such as Laval, Rüffert ${ }^{191}$ and Commission v Luxembourg ${ }^{192}$ have been much criticised for setting aside collective agreements and workers'

\footnotetext{
${ }^{186}$ Michael Dougan: The Spatial Restructuring of National Welfare States within the European Union: the Contribution of Union Citizenship and the Relevance of the Treaty of Lisbon in Ulla Neergaard, Ruth Nielsen and Lynn Roseberry (eds.): Integrating Welfare Functions into EU Law - From Rome to Lisbon, Copenhagen 2009.

${ }^{187}$ Act no 135 of 2004.

${ }^{188}$ Case C-341/05 Laval un Partneri [2007] ECR I-11767.

189 96/71/EC.

190 See Davies, Paul: Posted Workers: Single Market or Protection of National Labour Law Systems?, Common Market Law Review 1997 p. 571.

${ }_{191}$ Case C-346/06 [2008] ECR I-1989.

${ }^{192}$ Case C-319/06 [2008] ECR I-4323.
} 
rights in favour of free movement. ${ }^{193}$ This is due to the fact that the purposes of the Directive are partially conflicting. On the one side, it is intended to advance the free movement of services across the borders; on the other side, it shall ensure that the rights of workers are respected. ${ }^{194}$ This dual purpose of the Directive became topical in connection with the Eastern enlargement of the EU as of 1 May 2004. ${ }^{195}$ This is illustrated by Laval. The Posting of Workers Directive seeks to guarantee that posted workers will enjoy, whatever the law applicable to the employment relationship, the application of certain minimum protective provisions in force in the Member State where the work is performed. To this end, Article 3(1) of the Directive lays down the mandatory rules to be observed by employers during the period of posting in regard to among other issues: the minimum rates of pay when the pay is either fixed by minimum pay legislation or by collective agreements or arbitration awards which have been declared universally applicable within the meaning of Article (8) of the Posting of workers Directive, insofar as they concern the activities referred to in the Annex (i.e. the building sector). In most EU countries minimum wages are either fixed by legislation or universally applicable collective agreements. If Laval had posted workers to such a country, there is no doubt that Laval should have observed the pay rates applicable in the country where the work was performed. The Posting of Workers Directive does not allow a service provider from a low-pay country to move to a country with higher pay rates and perform work on the basis of his home country's low pay. Sweden and Denmark have chosen not to fix minimum pay by legislation or generally applicable collective agreements ${ }^{196}$ but by ordinary collective agreements (which are only binding for the parties) the conclusion of which are supported by collective action or threat of collective action. In a case before the Danish Labour Court, ${ }^{197}$ it stated on minimum wage in Denmark:

The Danish labour market regulation is characterized by the wage level etc. being ensured through collective agreements, not through legislation. The trade unions' freedom to take collective action to obtain collective agreements is therefore essential in achieving minimum wage etc. in this country.

In many respects, the above case before the Danish Labour Court was a Danish equivalent to Laval. The main difference was/is that the Danish Labour Court chose not to involve the ECJ and abstained from referring questions under Article 267 FEU (ex Article 234 EC). The Danish Labour

\footnotetext{
${ }^{193}$ See on these judgments Ruth Nielsen: Udstationering af arbejdstagere som led i udveksling af tjenesteydelser - Viking-, Laval- og Rüffert-sagerne, Arbeidsrett 2008 p. 61, Ronnie Eklund: A Swedish Perspective on Laval, Comparative Labor Law and Policy Journal 2008 p. 551 and for an article that argues for the right to benefit from the competitive advantage access to cheap labour gives, see Norbert Reich: Free Movement v. Social Rights in an Enlarged

Union - the Laval and Viking Cases before the ECJ, German Law Journal 2008 p 125, http://www.germanlawjournal.

$\mathrm{com} /$.

${ }^{194}$ See e.g. paragraph 5 in the preamble of the Directive.

${ }^{195}$ For an article arguing for the right of companies to use the potential advantage of access to low-cost labour, see Reich, Norbert: Free Movement v. Social Rights in an Enlarged Union - the Laval and Viking Cases before the ECJ, German Law Journal 2008 p. 125, http://www.germanlawjournal.com/.

${ }^{196}$ The Posting of Workers Directive provides in Article 3(8) that in the absence of a system for declaring collective agreements or arbitration awards to be of universal application, Member States may, if they so decide, base themselves on:

- collective agreements or arbitration awards which are generally applicable to all similar undertakings in the geographical area and in the profession or industry concerned, and/or

- collective agreements which have been concluded by the most representative employers' and labour organizations at national level and which are applied throughout national territory,

${ }^{197}$ A 2005.839. Available at the website of the Danish Labour Court http://www.arbejdsretten.dk/media/11550/a2005.839.pdf.
} 
Court held that it was sufficiently clear (i.e. acte clair) that the disputed collective action was not contrary to EU law on free movement.

The Laval case was about a Latvian company (Laval) which had won a contract for construction work at a school in the municipality of Vaxholm (Sweden) in an EU tender. In spring 2004, Laval posted Latvian building workers to a Swedish subsidiary of Laval to carry out the work. The Swedish trade union for building workers (byggnadsarbetarförbundet and one of its departments) demanded that Laval should accede to that trade union's general collective agreement with Swedish employers. According to that agreement, wages should be negotiated locally with a fall-back wage of 109 Swedish crowns. In autumn 2004, Laval entered into a collective agreement with the Latvian trade union for building workers. The level of pay in that agreement was much lower than the ordinary level of pay in Sweden. Between June and October 2004, some negotiations took place between Laval and the Swedish building workers union, but this did not lead to any result. On 19 October 2004, the Swedish building workers union sent a warning to Laval of industrial action in the form of blockade against all work on Laval work-places in Sweden. The blockade took effect 2 November. On 23 November 2004, the Swedish electrical workers union sent a warning of secondary (sympathetic) action against Laval. Laval claimed that the industrial action (blockade + secondary action) was an unlawful restriction in violation of Article 49 EC [now 56 FEU] on free movement of services and the Posting of Workers Directive ${ }^{198}$ and brought a case against the Swedish trade unions for building workers and electrical workers before the Swedish Labour Court 7 December 2004 demanding an interim injunction against the Swedish trade unions preventing them from taking industrial action and damages. The Labour Court turned down the demand for an interim injunction on 22 December 2004. At Christmas 2004, the posted Latvian workers went back to Latvia and did not return to the site in question. Laval went bankrupt in March 2005. On 29 April 2005, the Swedish Labour Court decided to refer preliminary questions to the ECJ on the interpretation of Article $57 \mathrm{FEU}$ (at the time of action Article 49 EC). The ECJ handed down its judgment on 18 December 2007. On 2 December 2009, the Swedish Labour Court handed down its judgment. ${ }^{199}$ The Labour Court awarded Laval damages from the trade unions with 4 votes to 3

In Swedish collective labour law (and similarly in the other Nordic countries), a blockade against an employer is an order from a trade union to its own members not to do work for that particular employer. This means that all unionised building workers in Sweden got an order from their trade union not to work for Laval. The blockade was a lawful main action. It had probably no coercive effect on Laval, because he had his own Latvian building workers and could do without work performed by Swedish building workers. The coercive effect in the industrial action was obtained through the next step: the secondary action or sympathetic action instigated by the electrical workers union. That measure had the effect of preventing Swedish electrical workers who were members of the electrical workers union and undertakings which were bound by collective agreements with the electrical workers union from providing work or services for Laval. That probably had the decisive coercive effect. The contracting authority (Vaxholm municipality) would

\footnotetext{
${ }^{198}$ 96/71/EC.

199 http://www.arbetsdomstolen.se/upload/pdf/2009/89-09.pdf . An unofficial translation by Erik Sjödin of the Swedish Labour Court's judgment in Laval into English may be found at the labour law portal http://arbetsratt.juridicum.su.se/
} 
probably not accept a school without electrical installations. Laval was therefore unable to perform the contract correctly due to the combined actions of the building and electrical workers unions. ${ }^{200}$ The ECJ held, as mentioned above in part 4, that the right to take collective action is a fundamental right under EU law which must be balanced against the right to free movement and that the Swedish trade unions had used industrial action in support of wage demands that were too unclear and nontransparent to be accepted as justified. The ECJ made the justification assessment itself and found that the collective action taken by the Swedish trade unions was incompatible with Article 49 EC [now Article 56 FEU] and the Posting of Workers Directive.

The literary comments on Laval are numerous. Most Nordic commentators have criticised Laval as disturbing - maybe even threatening - the distributive justice system in the Nordic welfare states. Many of the contributions to the Blurring Boundaries project comment on and criticise the ECJ's ruling in Laval. The obvious argument in favour of ECJ's Laval judgment would be that it protects the fundamental free movement rights of access for Eastern European workers and employers to the labour and services markets of the richer part of Europe. That viewpoint is hardly mentioned, let alone defended, in the contributions to the Blurring Boundaries project. That is probably (partly) due to the skewed composition of the group of authors participating in the Blurring Boundaries project with much weaker representation of scholars from Eastern Europe than from Northern Europe; see above in the Introduction.

On 2 December 2009, the Swedish Labour Court handed down its judgment. With 4 votes over 3 it ruled that the trade unions should pay damages to Laval. The Labour Court held that a duty for the trade unions to pay damages to Laval could not be based on Swedish law, but the Swedish Labour Court found a basis for such a liability in EU law. It stated: ${ }^{201}$

Det får vidare anses klarlagt att det finns en allmän rättsprincip inom EG-rätten om att skadestånd ska kunna utgå även mellan enskilda vid en överträdelse av en fördragsbestämmelse som har horisontell direkt effekt. Att denna princip inte endast gäller inom området konkurrensrätt utan även torde vara tillämplig beträffande brott mot andra fördragsbestämmelser framgår av domen i målet Raccanelli. ${ }^{202}$ Det finns emellertid inget konkret stöd i EG-dom-

\footnotetext{
${ }^{200}$ The ECJ apparently doesn't know what a collective labour law blockade is under Nordic law. (There are no EU law concepts on industrial action, the concepts are still defined by national law). The ECJ states in point 34: 'Blockading ('blockad') of the Vaxholm building site began on 2 November 2004. The blockading consisted, inter alia, of preventing the delivery of goods onto the site, placing pickets and prohibiting Latvian workers and vehicles from entering the site. Laval asked the police for assistance but they explained that since the collective action was lawful under national law they were not allowed to intervene or to remove physical obstacles blocking access to the site.' The date is correct, but the action described in point 34 of the ECJ judgment is not a collective labour law blockade but rather a demonstration maybe in the form of what some would call a physical blockade. A physical blockade is not a labour law action under Nordic law and is not what the main Laval case (the case dealt with by the Swedish Labour Court) was about. The Swedish Labour Court case was a traditional (Nordic) collective labour law case about industrial action as described above. There is nothing in the Swedish Labour Court's description of the case in its judgment from December 2009 that resembles the above description in point 34 of the ECJ judgments. Readers who are able to read the Swedish Labour Court's judgment should use that Court's description of the dispute rather than the one given by ECJ. In point 37 of the Laval judgment a more realistic description of the sympathetic action is given.

${ }^{201}$ It means (translated by Neergaard and Nielsen): It must be regarded as clarified that there is a general principle of Community law according to which damages should be due even between private individuals in case of an infringement of a Treaty provision with horizontal direct effect. That this principle not only applies in the field of competition law, but also should be applicable as regards breaches of other provisions of the Treaty is clear from the Raccanelli-case. However, there is no concrete support in the case law of the ECJ for the interpretation that a private individual should pay compensation to another private individual for breach of Article 56 FEU [ex Article 49 EC].

${ }^{202}$ No footnote in the original. Footnote added by Neergaard and Nielsen. The Raccanelli case is case C-94/97 [2008] ECR I-5939. The case is about a migrant worker and the interpretation of Article 45 FEU [ex Article 39 EC].
} 
stolens praxis för att en enskild ska betala skadestånd på EG-rättslig grund till en annan enskild vid brott mot just artikel 49 EG.

The Swedish Labour Court held that trade unions are liable in damages under EU law on the same conditions as apply to state liability under EU law, i.e. three conditions must be met: ${ }^{203}$

- The EU law breached must have been intended to confer rights on individuals;

- The breach must be sufficiently serious;

- There must be a direct causal link between the state's breach and the loss suffered.

That view, which as mentioned was held by 4 votes to 3, is not obviously correct, and it has already given rise to a lot of further debate. The Laval case is now pending before the Swedish Supreme Court. Usually, a judgment from the Swedish Labour Court is final and cannot be appealed. Under the Swedish Administration of Justice Act there is, however, on strict conditions, a possibility of nullification of a judgment and of re-opening a case ${ }^{204}$ which cannot be appealed if serious errors have been committed. On 6 May 2010, the Swedish LO on behalf of the trade unions that lost in the Laval case, asked the Swedish Supreme Court to re-open the case. It argues that the Labour Court applied EU law in a fundamentally wrong way and that it was a serious procedural error that the Swedish Labour Court did not refer questions to the ECJ under Article 267 FEU on whether there, as held by the Swedish Labour Court, in cases where Article 56 FEU has been violated, is a general principle in EU law under which trade unions are liable in damages as a result of Article 56 FEU's direct, horizontal effect.

The ECJ's judgment in Laval is open to different interpretations. Danish and Swedish rules have traditionally been more or less alike when it comes to trade unions' right to take collective action against employers. In March 2008, the Danish Ministry of Employment therefore set up a Laval committee consisting of representatives of the main social partners (in particular Danish LO and the Danish Employers' Association) and civil servants from the relevant ministries to examine whether it was desirable to change anything in Danish law to accommodate the ECJ judgment in Laval. The task of the Laval committee was to suggest a solution which upholds the Danish model of labour market regulation by combining EU law on free movement and Danish collective labour law in a way that is not in obvious violation of neither EU law nor the Danish collective labour law tradition. The Committee delivered its report in June 2008. It unanimously suggested a new provision on the right to take collective action in respect of posted workers in the Danish Posting of Workers Act. During the autumn of 2008, the new provision was adopted by the Danish Parliament. The new provision reads: ${ }^{205}$

$\S 6$ a. With a view to ensuring posted workers wages equivalent to what Danish employers are required to pay for the performance of similar work, there is freedom, in the same way as against Danish employers, to take collective action against foreign service providers in support of a demand for a collective agreement.

\footnotetext{
${ }^{203}$ Joined Cases C-46 and C-48/93 Brasserie du Pêcheur v Federal Republic of Germany and R v Secretary of State for Transport ex parte Factortame Ltd [1996] ECR I-1029.

204 'Undanröjning' on grounds of.'domvilla' and 'Resning' in Swedish.

${ }^{205}$ See Ruth Nielsen: Scandinavian Legal Realism and EU Law in Ulla Neergaard, Ruth Nielsen and Lynn Roseberry (eds.): The Role of Courts in Developing a European Social Model - Theoretical and Methodological Perspectives, Copenhagen 2010.
} 
2. It is a condition for commencement of collective action as provided for in subsection 1 that reference in advance has been made to the foreign service provider to provisions in collective agreements concluded by the most representative labour market organisations in Denmark that apply on the whole Danish territory. It must from these collective agreements appear with sufficient clarity which wage must be paid according to the collective agreement.

The new provision builds on and confirms the basic features of Danish collective labour law, where collective agreements limit the possibility for employers to compete against each other by paying lower wages than those provided for in ordinary Danish collective agreements. Denmark has no minimum wage legislation (adopted by Parliament) and no generally applicable collective agreements. The main social partners are agreed that they do not want to change that. The new provision in the posting of workers Act changes practically nothing in Danish law, ${ }^{206}$ but it confirms the right of Danish trade unions to take industrial action in support of ordinary Danish collective agreements in by and large the same circumstances as before the ECJ judgment in Laval. There is and will - also in the future - be no minimum wage legislation in Denmark, no universally applicable collective agreements and only very limited freedom for employers to compete on low wages. The Danish government presents the amendment as an example of how a Member State where universally applicable collective agreements are absent, according to Article 2(8) of the Posting of Workers Directive, can base itself on collective agreements which have been concluded by the most representative organisations at national level and which are applied throughout the national territory when fixing minimum wages. Pursuant to the Posting of Workers Directive, the term 'minimum wage' is defined in accordance with national law and/or case law in the Member State in whose area the worker is posted, ${ }^{207}$ i.e. in Laval, according to Swedish law (and not EU law). Nevertheless, the ECJ expressed its view on whether the claim at issue was a minimum wage claim (and held that it was not). Danish minimum wages are traditionally fixed by collective agreements the conclusion of which is supported by collective action or threat of collective action.

What is considered minimum wage under Danish labour law is the whole pay package provided for in a collective agreement and not just the lowest figure one can find in the agreement. It may comprise several wage components, including for example insurance for the workers, which the employer is obliged to pay under the collective agreement. There is, and has for many years been, freedom for trade unions to take collective action in support of the whole pay package in a collective agreement. Seen from the perspective of Scandinavian legal realism, the prognosis is that that remains unchanged after the Posting of Workers Act has been amended following the ECJ's Laval judgment.

\subsection{Preliminary Conclusions}

The ECJ tends to interpret EU internal market in a way that sees limitation of market access as discrimination. As Barnard argues: ${ }^{208}$

\footnotetext{
${ }^{206}$ Non-representative trade unions lose, however, their right to take collective action against employers who exercise their right to free movement, and industrial action against such employers can after the amendment of the legislation only be taken in support of nation-wide collective agreements.

${ }^{207}$ See Art. 3(1) in fine of the Posting of Workers Directive.

${ }^{208}$ Catherine Barnard, "EU Citizenship and the Principle of Solidarity", in Michael Dougan \& Eleanor Spaventa (eds.), Social Welfare and EU Law, Hart Publishing, 2005, pp. 177-178.
} 
[The ECJ] merely applied its non-discrimination/market access analysis with full rigour and inevitably found the national rules to be discriminatory and thus unlawful. While the result of judgments such as Cowan, Gravier and Kohll might be to make the migrant tourist/student/healthcare seeker feel more communautaire, it also has the effect of imposing greater burdens - not on the EU (the granter of the rights) - but on the exchequers of the states most affected.

Seen from a Nordic perspective, the single most controversial ECJ judgment in the social field is Laval, which illustrates the clash between a European Social Model based on access justice at EU level and national welfare states with highly developed distributive justice systems at national level, in the Laval case that part of the national distributive justice system that deals with minimum wages. The ECJ's judgment in Laval is open to different interpretations. In Denmark, the main social partners, the government and the parliamentary legislator have chosen to interpret the ECJ judgment as only requiring transparency in the way access to the Danish labour market is hindered but not as preventing Denmark from upholding its way of fixing minimum wages.

Neergaard concludes her analysis ${ }^{209}$ of the concept of solidarity in EU law by stating that "solidarity" in EU law is important. It is right in the heart of the many tensions at present between EU law and national welfare states. It is a concept which has an enormous potential as an explanatory factor and as a general legal principle in horizontal terms. It will also play an increasing role as a value and an identity as well as in relationship to fundamental rights.

\section{Fundamental Social Rights and Non-Discrimination}

\subsection{The Danish Development from a Non-Constitutional to a Constitutional Approach to} Fundamental Social Rights and Non-discrimination

A main feature of the development from the Danish welfare state as it was on 1 January 1973, when Denmark entered the EC to the multi-level European Social Model, as it is anno 2010, is the shift from a non-constitutional to a constitutional approach to fundamental social rights and nondiscrimination. For countries like Denmark with a strong tradition of majoritarian, parliamentary democracy and no constitutional courts, the EU development results in a pressure to accept constitutional review of legislation by courts such as the ECJ.

\subsubsection{Majoritarian, Parliamentary Democracy versus Constitutional Democracy}

Within the different forms of political democracy that are practiced at national level in the EU a distinction can be drawn between, on the one hand, majoritarian, parliamentary democracy, which is used in Denmark and the other Nordic countries and the UK and, on the other hand, constitutional democracy, ${ }^{210}$ which is used in a number of other EU Member States; see further

\footnotetext{
${ }^{209}$ Ulla Neergaard: In Search of the Role of 'Solidarity' in Primary Law and the Case Law of the European Court of Justice in Ulla Neergaard, Ruth Nielsen and Lynn Roseberry (eds.): The Role of Courts in Developing a European Social Model - Theoretical and Methodological Perspectives, Copenhagen 2010.

210 See Marlene Wind, Dorte Sindbjerg Martinsen and Gabriel Pons Rotger: The Uneven Legal Push for Europe - Questioning Variation when National Courts go to Europe, European Union Politics No 4, 2008. See also Marlene Wind's description of her research interests at her website http://www.cep.polsci.ku.dk/forskere/mwi/ where she writes: 'Jeg skelner her imellem 'majoritarian democracy' som vi kender fra Danmark og i nordiske lande, hvor det parlamentariske flertal står i centrum og så det 'konstitutionelle demokrati' i det meste af det øvrige Europa, hvor man lægger stor vægt på domstolskontrol med lovgivningsmagten. Min tese er at vores demokratiform med 'ingen over eller ved siden af Folketinget' ikke passer særlig godt med den form man finder i EU og i resten af Europa.', it means (translated by Neergaard and Nielsen): 'I distinguish between 'majoritarian democracy' as we know from
} 
below in section 7.1.3. on the separation of power between parliaments and courts. In labour and welfare law constitutional democracy is particularly highly developed in Germany.

Denmark entered the EC in 1973 as a majoritarian, parliamentary (and non-constitutional) democracy. As pointed out in section 2, Denmark has traditionally not protected fundamental social rights or the principle of non-discrimination in the text of the Constitution and the Danish courts which are not elected and therefore are not seen as having political legitimacy - have by and large abstained from deciding matters of (party) political importance.

Originally - when the EC was founded in the 1950'ies - EC law was mainly of an economic character. The EU only later developed into a more political union and now seems to be in the process of developing into a kind of constitutional democracy. After the adoption in 2000 of the Charter of Fundamental Rights of the European Union, it has become usual in academic literature to talk about constitutionalisation of the EU. ${ }^{211}$ As mentioned above in section 4, von Bogdandy understands EU primary law as constitutional law. In favour of this terminology he refers to the fact that the primary law justifies the exercise of public power, it legitimises acts of the EU, it creates a citizenship, it grants fundamental rights, and it regulates the relationship between legal orders, between public power and the economy, and between law and politics. Numerous common elements of EU primary law and national constitutions thus emerge in a functional comparison. ${ }^{212}$

The distinction between constitutional democracy and majoritarian, parliamentary democracy is linked to the distinction between the monist and dualist approach to the relationship between international and national law. In its pure form, the monist approach considers the rules of international law to be part of the domestic legal system and requires the courts to apply them directly. Conflicts between international law and rules of domestic origin may in a monist system be solved in various ways, for example by giving priority to international law, to the domestic rules, to the domestic rules of a certain rank, etc. Under EU law, international treaties entered into by the EU form part of EU law without any incorporation being necessary. EU law is thus based on the monist approach. The monist approach fits well with the structure of a constitutional democracy.

The Scandinavian countries, on the other hand, have traditionally followed the dualist approach according to which international law is a separate legal system, not directly applicable in national courts. In the dualist approach the national parliament serves as a 'gate-keeper' that controls the influx of public international law into national law. This means that conflicts between international and domestic law can in principle not arise before national courts, which are not allowed to apply international law directly but have a duty to interpret national law in accordance with international law if that is possible. In order for treaties ratified by 'dualist' states to become part of national law,

Denmark and the Nordic countries, where the parliamentary majority is at the centre and the constitutional democracy in most of the rest of Europe, where great emphasis is put on judicial control of the legislature, My thesis is that our form of democracy with 'no one above or at the side of the parliament (the Folketing)' does not fit well with the form of democracy one finds in the EU and the rest of Europe.'

${ }^{211}$ There is an abundant academic literature on constitutionalisation of the EU, see among many Beate Rudolf: European Union, International Journal of Constitutional Law 2003 p. 135, Gráinne de Búrca and Jo Beatrix Aschenbrenner: The Development of European Constitutionalism and the Role of The EU Charter of Fundamental Rights, Columbia Journal of European Law 2003 p. 355, Udo Di Fabio: A European Charter: Towards a Constitution for the Union, Columbia Journal of European Law 2001 p. 159 , Koen Lenaerts and Eddy de Smijter: A “Bill of Rights” for the European Union, Common Market Law Review 2001 p. 273 and Ingolf Pernice: Integrating the Charter of Fundamental Rights into the Constitution of the European Union: Practical and Theoretical Propositions, Columbia Journal of European Law 2003 p. 5.

${ }^{212}$ See further Von Bogdandy, Armin: Founding Principles of EU Law: A Theoretical and Doctrinal Sketch, European Law Journal, 2010 p. 95. 
they must be incorporated by national legislation of some kind, i.e. by the national parliament. In most cases the Scandinavian courts will be able to interpret domestic law so as to comply with the country's international obligations, but on a few occasions the principled dualist approach has been upheld by the courts.

Membership of the EU places the Nordic countries in a double context. The Nordic member states are now both 'monists' as EU states and 'dualist' as individual nation-states. This new context incites a shift in approach from the dualist to the monist theory. In respect of public international law, the traditional Scandinavian preference for the dualist theory is being softened, and a more mixed monist and dualist approach is being developed.

\subsubsection{Multi-level Constitutionalism}

Ingolf Pernice ${ }^{213}$ uses the concept multi-level constitutionalism to name a dynamic process of constitution-making instead of a sequence of international treaties which establish and develop an organisation of international cooperation. Seen in this perspective, the European Social Model today (2010) has a multi-level constitution made up of the constitutions of the Member States bound together by a complementary constitutional body consisting of the European Treaties (since the coming into force of the Lisbon Treaty, the Treaty on the European Union, the Treaty on the Functioning of the European Union and the Charter of Fundamental Rights) and a number of general principles of EU law including the principle of non-discrimination.

\subsubsection{Separation of Power between Legislators and Courts}

In a majoritarian, parliamentary democracy, the parliamentary majority is the central authority and source of legitimacy. Legitimacy in such a system is based on representativity. As Føllesdal ${ }^{214}$ states:

Nordic public debates have tended to conflate legitimacy and majoritarian parliamentarianism. Parliament is seen as the site of legitimacy, as the privileged arena for the expression of the general will. There are no Constitutional Courts, and the constitutions and constitutional conventions leave great scope to parliamentary discretion. Thus it is for the Parliaments themselves to decide whether legislation is within the bounds of the constitution.

In Denmark, legislative power concerning the labour market - with regard to the problems dealt with in the Blurring Boundaries project for example the legislative power to fix minimum wages is largely delegated from the parliamentary legislator to the social partners ${ }^{215}$ which are also representative and therefore enjoy the same kind of legitimacy as the parliamentary legislator. Denmark has no statutory Act on minimum wages but as described above in section 6.3, the Danish Labour Court ${ }^{216}$ in 2005 in a very Laval-like case stated on minimum wages in Denmark that the Danish labour market regulation is characterised by the wage level etc. being ensured through collective agreements, not through (parliamentary) legislation. Danish labour law evolved during the first part of the 20th century into a semi-autonomous legal discipline which was to a

\footnotetext{
${ }^{213}$ Pernice, Ingolf: Multilevel Constitutionalism and the Treaty of Amsterdam: European Constitution-Making Revisited?, Common Market Law Review 1999 p. 703.

${ }^{214}$ Føllesdal, Andreas: Rawls in the Nordic Countries, European Journal of Political Theory 2002 p. 181.

${ }^{215}$ See Nielsen, Ruth: Europeanization of Nordic Labour Law in Scandinavian Studies in Law Volume 43, Stability and Change in Nordic Labour Law, Stockholm 2002 p. 37.

${ }^{216}$ A 2005.839. Available at the website of the Danish Labour Court http://www.arbejdsretten.dk/media/11550/a2005.839.pdf.
} 
considerable extent left to the main Danish social partners, in particular the Danish Employers' Organisation (DA) and the Confederation of Trade Unions (Danish LO). In Denmark, the social partners serve both as legislators, judges and litigators. The labour market organisations fulfil legislative functions mainly through the adoption of collective agreements. They have adjudicative functions mainly by participating as lay judges in the special labour courts and industrial tribunals. Finally, trade unions are the main litigators in Danish labour law, both in collective labour law cases adjudicated by the special Labour Court/industrial tribunals and in individual employment law cases adjudicated by the ordinary courts. Collective agreements are thus, in a Danish context, the key both to the legislative and the adjudicative function of the social partners. They typically prefer this means for implementing EU labour law directives in order to maintain their roles as legislators and judges. ${ }^{217}$ Article 28 of the Charter of Fundamental Rights in the EU ${ }^{218}$ protects the right of trade unions to fix wages by means of collective agreements and to take collective action in support of such agreements; see above in section 6.3 on the Laval judgment. The concept of collective action in Article 28 of the Charter is an example of a multi-level concept. As set out above in section 6.3, the decisive coercive element in Danish and Nordic collective actions against employers who have not previously been bound by collective agreements is the secondary action which is lawful in Nordic law. In some other countries, for example, UK law, secondary action is prohibited and is not regarded as protected by the fundamental right to take collective action. In the Laval judgment the ECJ abstained from interfering with what kind of coercive actions could be used in support of collective agreements and only held that a level of transparency must be assured in order to respect the principle of free movement of services while exercising the right to take collective action.

In majoritarian, parliamentary democracies there are no constitutional courts, and the ordinary courts do by and large not control whether the legislator respects the constitution and the fundamental rights that may be included in its text. In contrast, judicial review of the exercise of legislative power and control of the legislator's compliance with fundamental, constitutional rights is an important element in constitutional democracies. The multi-level constitutional context Denmark became part of through its membership of the EU has been a challenge to traditional Danish (and Nordic) views on the separation of powers between legislators and courts. As Martin Scheinin states: ${ }^{219}$

In the Nordic countries it is customary to state that it is the legislator that makes, through adopting and amending laws, all important decisions on policies and principles. The role of courts of law is seen as implementing the will of the legislator. Within Community law the situation is different as the normative framework of Community law is incomplete as a legal system and as the European Court of Justice (ECJ), consequently, has a strong position in the development of the law and in securing coherence in law.

\footnotetext{
${ }^{217}$ See further Nielsen, Ruth: Implementation of EC Directives in Denmark, International Journal of Comparative Labour Law and Industrial Relations 2002 vol. 18, issue 4.

${ }^{218}$ Article 28 reads: Workers and employers, or their respective organisations, have, in accordance with Community law and national laws and practices, the right to negotiate and conclude collective agreements at the appropriate levels and, in cases of conflicts of interest, to take collective action to defend their interests, including strike action.

219 Scheinin, Martin: Constitutionalism and Approaches to Rights in the Nordic Countries, in Nergelius, Joakim (ed.): Constitutionalism: New Challenges. European Law from a Nordic Perspective, Leiden/Boston 2008.
} 
The ECJ started as an administrative court mainly set up to control EC/EU institutions but has over the years developed into a court that resembles constitutional courts like the American Supreme Court or the German Bundesverfassungsgericht - a development that has attracted criticism from both Euro-sceptic political parties in Denmark and in Danish academic literature. ${ }^{220}$

The 2009 conference held within the framework of the Blurring Boundaries project centred on the role of courts in developing a European Social Model. ${ }^{221}$ The book contains ten contributions altogether, each of which addresses different dimensions of the general theme. The three contributions in Part One are written by Hans-W. Micklitz, Dagmar Schiek, and Ulla Neergaard. Each of these essays represents a horizontal approach to the European courts' role(s) in the development of the European Social Model in that each essay examines the courts' treatment of issues arising across different subject areas. For example, Micklitz looks at anti-discrimination law, consumer law, and universal services. Part Two includes contributions from Eleanor Spaventa, Mia Rönmar and Lynn Roseberry. Each of these contributions considers the courts' role(s) in a specific subject area: Spaventa on citizenship, Rönnmar on labour, and Roseberry on fundamental rights. The final part consisting of four essays by Ruth Nielsen, Finn Arnesen, Joxerramon Bengoetxea and Antonina Bakardjieva Engelbrekt investigates more explicitly theoretical and methodological aspects; see for further detail Annex 1.

\subsubsection{Constitutional Rights}

Robert Alexy ${ }^{222}$ states that the role of constitutional rights in a legal system depends on four closely connected points: (1) their binding force, (2) their institutionalisation, (3) their content, and (4) their structure. According to him, there is a broad consensus on the question that if a constitution includes constitutional rights, they should as Article 1(3) of the German Grundgesetz ${ }^{223}$ puts it 'bind the legislature, the executive and the judiciary as directly applicable law', and this binding power should be guaranteed by means of some kind of institutionalised power, be it a constitutional court or some other body. Such a consensus probably exists in constitutional democracies, but it does not extend to majoritarian democracies like Denmark as it was before Denmark's entry into a new constitutional context through membership of the EU.

In the Danish Constitution, Chapter 8 deals with Citizens' rights. This chapter only covers some civil and political rights (personal liberty, ownership, freedom of expression, freedom of association, freedom of assembly, etc.) but no social rights, and there is no constitutional guarantee of the principle of non-discrimination in Denmark (apart from what follows from EU law). On the Danish Parliament's website, there is a semi-official translation into English of the Danish constitution with explanatory remarks. ${ }^{224}$ Here it is stated:

\footnotetext{
${ }^{220}$ See Rasmussen, Hjalte: On Law and Policy in the European Court of Justice, Dordrecht 1986.

${ }^{221}$ See Ulla Neergaard, Ruth Nielsen and Lynn Roseberry (eds.): The Role of Courts in Developing a European Social Model Theoretical and Methodological Perspectives, Copenhagen 2010.

${ }^{222}$ Alexy, Robert: Constitutional Rights and Legal Systems, in Nergelius, Joakim (ed.): Constitutionalism: New Challenges. European Law from a Nordic Perspective, Leiden/Boston 2008.

${ }^{223}$ Article 1(3) of the German Grundgesetz reads: (3) Die nachfolgenden Grundrechte binden Gesetzgebung, vollziehende Gewalt und Rechtsprechung als unmittelbar geltendes Recht.

${ }^{224}$ http://www.ft.dk/English/ /media/Pdf_materiale/Pdf_publikationer/English/My\%20Constitutional\%20Act_samlet_web\%20pdf.as $\underline{\mathrm{hx}}$.
} 
Part eight deals with citizens' rights and freedoms. This is referred to as the Constitutional Act's Part on constitutional rights or human rights. In 1992, Parliament passed an Act adopting the provisions of the European Convention on Human Rights in Denmark. Many of the rules in the European Convention on Human Rights go further in their protection of human rights than is the case with the Danish Constitutional Act.

As will appear from the following sections, one of the main differences between the human rights protection offered by the ECHR and the protection of fundamental rights in the EU is that EU law protects not only civil and political rights more or less in the same way as the ECHR does but in addition fundamental social rights and non-discrimination to a much larger extent than the ECHR does.

According to Robert Alexy, ${ }^{225}$ there are two main constructions of constitutional rights: one is narrow and strict, and the other is broad and comprehensive. The first can be called the rule construction, the second the principle construction. Under the rule construction deciding whether or not a constitutional right has been violated depends on whether the relevant facts can be subsumed under the rule, under the principle construction a balancing of colliding constitutional principles is required. There is not agreement among German scholars as to whether the constitutional rights in the German Grundgesetz should be interpreted under the rule construction or the principle construction. Alexy argues that from a methodological point of view, the concept of balancing is the central concept in the adjudication of the German Bundesverfassungsgericht. The contributions provided within the framework of the Blurring Boundaries project suggest that the same is true as far as the ECJ is concerned. ${ }^{226}$

\subsection{The EU Development of Protection of Fundamental Social Rights and Non-discrimination}

\subsubsection{The Distinctions between Civil and Political Rights and Social and Economic Rights}

Civil and political rights have received broad support and recognition at both a theoretical and practical level in Western liberal democracies and have also been guaranteed according to the text of the Danish Constitution; see above on Chapter 8 of the Danish Constitution. Economic and social rights, on the other hand, tend to have a subordinate status and remain highly contested. ${ }^{227}$

The UN Universal Declaration of Human Rights contains both civil, political, economic, social and cultural rights within one text and proclaims their universality and indivisibility. In 1952, when the ideological conflict between the Soviet Union and Western liberal democratic states had become clear, it was decided to adopt two separate Conventions on human rights divided into civil and political rights in one convention and social, economic and cultural rights in another convention. On 16 December 1966, the International Covenant on Civil and Political Rights (ICCPR) and the International Covenant on Economic, Social and Cultural Rights (ICESCR) were adopted. The distinction between civil and political rights on the one hand and social and economic rights on the

\footnotetext{
225 Alexy, Robert: Constitutional Rights and Legal Systems, in Nergelius, Joakim (ed.): Constitutionalism: New Challenges. European Law from a Nordic Perspective, Leiden/Boston 2008. See also Alexy, Robert: Theorie der Grundrechte and Alexy, Robert: Constitutional Rights, Balancing and Rationality, Ratio Juris 2003 p. 131.

${ }^{226}$ See for example the discussions of the Laval case in Hans-W. Micklitz: Judicial Activism of the European Court of Justice and the Development of the European Social Model in Anti-Discrimination and Consumer Law and Ruth Nielsen: Scandinavian Legal Realism and EU Law both in Ulla Neergaard, Ruth Nielsen and Lynn Roseberry (eds.): The Role of Courts in Developing a European Social Model - Theoretical and Methodological Perspectives, Copenhagen 2010.

${ }^{227}$ Kenner, Jeff: Economic and social Rights in the EU Legal Order in Hervey, Tamara and Jeff Kenner (eds.): Economic and Socila Rights under the EU Charter of Fundamental Rights: A Legal Perspective, Oxford 2003.
} 
other was also made by the Council of Europe. The European Convention on Human Rights (ECHR), which addresses primarily civil and political rights was adopted in 1950. Economic and social rights were addressed eleven years later in the European Social Charter of 1961.

In EU law, the Charter of Fundamental Rights 2000/2007 protects not only civil and political rights more or less in the same way as the ECHR does but in addition fundamental social rights and non-discrimination to a much larger extent than the ECHR does. In her contribution to the Blurring Boundaries project, Lynn Roseberry argues that the ECJ gives higher priority to civil and political rights than to social and economic rights. ${ }^{228}$ In her view, the elimination of discrimination does not clearly belong to either category of human rights, as the principle of non-discrimination on specified grounds appears in conventions protecting both kinds of rights. The ECHR, the European Social Charter, the ICCPR and the ICESCR all require parties to these conventions to guarantee the human rights enumerated in the conventions to everyone regardless of sex and a number of other grounds. Commentators to EU law with a background in labour law and discrimination law usually see the process of developing the European Social Model as starting in the early 1970's. ${ }^{229}$ Authors with a background in competition law or internal market law often see it as starting later and generally put less emphasis on social rights and anti-discrimination. Some authors even regard it as a myth that the European Social Model exists. Beryl Philine ter Haar and Paul Copeland thus state: 230

The European Social Model (ESM) is one of the most contested aspects of the European integration process. That European integration has been anything more than a simple market-making process is hugely contested.

\subsubsection{Treaty Provisions}

The original Treaty of Rome 1957 did not contain specific provisions on the protection of fundamental rights. Article 6 EU was first included in the Treaty on European Union (the Maastricht Treaty), signed in 1992, and was subsequently amended by the Amsterdam Treaty in 1997 and the Lisbon Treaty in 2007. Pre-Lisbon it provided that the Union must respect fundamental rights as guaranteed by the ECHR and as they result from the constitutional traditions common to the Member States, as general principles of Community law. The Lisbon Treaty substantially revised Article 6 EU. The most important change relates to the legal status of the Charter of Fundamental Rights in the European Union. Article 6 EU now (post-Lisbon) reads as follows:

The Union recognises the rights, freedoms and principles set out in the Charter of Fundamental Rights of the European Union of 7 December 2000, as adapted at Strasbourg, on 12 December 2007, which shall have the same legal value as the Treaties.

The provisions of the Charter shall not extend in any way the competences of the Union as defined in the Treaties.

The rights, freedoms and principles in the Charter shall be interpreted in accordance with the general provisions of Title VII of the Charter governing its interpretation and application and with due regard to the explanations referred to in the Charter, that set out the sources of those provisions.

\footnotetext{
${ }^{228}$ See Lynn Roseberry: International Human Rights Treaties and Fundamental Rights in the Case Law of the European Court of Justice: Pointing towards a European Social Model? In Ulla Neergaard, Ruth Nielsen and Lynn Roseberry (eds.): The Role of Courts in Developing a European Social Model - Theoretical and Methodological Perspectives, Copenhagen 2010.

${ }^{229}$ See for example Bob Hepple and Bruno Veneziani (eds.): The Transformation of Labour Law in Europe, Oxford 2009.

${ }^{230}$ Beryl Philine ter Haar and Paul Copeland: What are the Future Prospects for the European Social Model? An Analysis of EU Equal Opportunities and Employment Policy, European Law Journal 2010 p. 273.
} 
Article 51 of the Charter stipulates that the provisions of the Charter are addressed to the institutions, bodies and organs of the EU with due regard for the principle of subsidiarity and to the Member States only when they are implementing Union law. The question whether the EU can accede to the ECHR was answered in the negative in 1996. ${ }^{231}$ The amended Article 6 EU (postLisbon) provides that the Union shall accede to the ECHR. Article 151 FEU refers to the fundamental social rights such as those set out in the European Social Charter signed at Turin on 18 October 1961 and in the 1989 Community Charter of the Fundamental Social Rights of Workers. See further on the Charter of Fundamental Rights, below in section 7.3.

\subsubsection{Policy Statements by the EU Legislator}

On 5 April 1977, the European Parliament, the Council and the Commission issued a joint declaration $^{232}$ in which they stressed the prime importance they attached to the protection of fundamental rights, as derived in particular from the constitutions of the Member States and the ECHR. The ECJ has occasionally referred to this Declaration. ${ }^{233}$

In $1989,{ }^{234}$ eleven of the then 12 members of the EC adopted the Community Charter of Fundamental Rights of Workers. ${ }^{235}$ There are references to this Charter both in Article 151 FEU and in the explanatory remarks to the Charter of Fundamental Rights of the European Union 2000.

In 1999, when the European Council decided to draw up a Charter of Fundamental Rights of the European Union, it adopted some broad guidelines on what the Charter should contain. It declared (emphasis added): ${ }^{236}$

The European Council believes that this Charter should contain the fundamental rights and freedoms as well as basic procedural rights guaranteed by the European Convention for the Protection of Human Rights and Fundamental Freedoms and derived from the constitutional traditions common to the Member States, as general principles of Community law. The Charter should also include the fundamental rights that pertain only to the Union's citizens. In drawing up such a Charter account should furthermore be taken of economic and social rights as contained in the European Social Charter and the Community Charter of the Fundamental Social Rights of Workers (Article 136 TEC), insofar as they do not merely establish objectives for action by the Union.

At the European Council in Nice in December 2000, when the Charter of Fundamental Rights in the European Union was adopted as a soft law declaration, the heads of states and governments also

\footnotetext{
${ }^{231}$ Opinion 2/94 [1996] I-1759.

232 OJ 1977 C 103.

${ }^{233}$ See for example Case 44/79 Hauer [1979] ECR 3727 and Case 222/84 Johnston [1986] ECR 1651.

${ }^{234}$ Bercusson, Brian: The European Community's Charter of Fundamental Social Rights of Workers, The Modern Law Review, Vol. 53, 1990 p. 624.

${ }^{23}$ http://www.aedh.eu/plugins/fckeditor/userfiles/file/Conventions\%20internationales/Community Charter of the Fundamental So cial_Rights_of_Workers.pdf.

${ }^{236}$ Conclusions of the presidency of the European Council of Cologne (3 and 4 June 1999) on the drawing up of a Charter of Fundamental Rights of the European Union, Annex 4 p. 43, available at http://www.consilium.europa.eu/ueDocs/newsWord/en/ec/57886.doc. See on the background to the Charter de Búrca, Gráinne: The drafting of the European Union Charter of fundamental rights, European Law Review 2001 p. 126, Lammy Betten: The EU Charter of Fundamental Rights: a Trojan Horse or a Mouse?, International Journal of Comparative Labour Law and Industrial Relations 2001 p. 151, Deirdre Curtin: The EU Human Rights Charter and the Union Legal Order: the 'Banns’ before the Marriage?, in D. O’ Keeffe and A. Bavasso (eds.), Liber Amicorum in honour of Lord Slynn of Hadley: Judicial review in European Union Law, Kluwer 2000, Engel, Christoph: The European Charter of Fundamental Rights: A Changed Political Opportunity Structure and its Normative Consequences, European Law Journal 2001 p. 151 and Fredman, Sandra, Christopher McCrudden and Mark Freedland: An EU Charter of Fundamental Rights, Public Law 2000 p. 178.
} 
adopted a European social agenda, where the European Council stated ${ }^{237}$ that the 'European social model has developed over the last forty years'. Dating the beginning of the European Social Model back to around 1960 is, as Fernando Valdés dal-Ré states, ${ }^{238}$ a 'calculated exaggeration' by the leaders of the EU. As appears from section 2, the first policy statements laying the basis for a European Social Model were the declarations of the heads of states and governments at the Paris summit in 1972 and the first Social action programme from 1974, and the first judgments from the ECJ on fundamental social rights were Rutili ${ }^{239}$ from 1975 and Defrenne II and III from 1976 and 1978. ${ }^{240}$

\subsubsection{The Case Law of the ECJ on Fundamental Rights}

Since 1970, the ECJ has developed a case law on fundamental rights, primarily on civil and political rights and discrimination but also on some fundamental trade union rights but not on other social rights. Starting in the late nineteen sixties, increasing concern was expressed in the courts of Germany and Italy on the question as to whether the fundamental rights guaranteed in their national constitutions were recognised and protected within EU law. In response to the threat that national courts would opt for the supremacy of their own national constitutional provisions on fundamental rights protection, the ECJ held that the protection of fundamental rights was a general principle of EU law.

In 1969 in Stauder, ${ }^{241}$ the ECJ for the first time stated that fundamental rights were enshrined in the general principles of Community law and protected by the ECJ. In Internationale Handelsgesellschaft the reference to fundamental rights was expanded by the ECJ stating that respect for fundamental rights forms an integral part of the general principles of law protected by the ECJ and that these principles were inspired by the constitutional traditions common to the Member States. ${ }^{242}$ Before 1 January 1973 all EC Member States were constitutional democracies. Since Denmark's and the UK's entry into the EC/EU 1 January 1973, the constitutional traditions of the Member States have been less uniform than they originally were. In 1974, the ECJ held in Nold $^{243}$ that, in addition to Member States' constitutional traditions, international conventions could also supply guidelines which could be taken into consideration by the ECJ on matters concerning claims to fundamental rights. In particular, the ECHR has a special significance in this respect.

Fundamental rights were first specifically referred to in a labour and welfare law case in 1975 in Rutili. $^{244}$ Of specific relevance to welfare rights of migrant workers are Defrenne-III, ${ }^{245}$ where the ECJ stated that there can be no doubt that the elimination of discrimination based on sex forms part of the fundamental rights. In Maurissen, ${ }^{246}$ the ECJ held that in staff cases an EU institution must

\footnotetext{
${ }^{237}$ http://www.europarl.europa.eu/summits/nice2_en.htm\#an1.

238 Edoardo Ales, Teun Jaspers, Pascale Lorber, Corinne Sachs-Durand, Ulrike Wenderling-Schröder (Eds.): Fundamental Social Rights in Europe: Challenges and Opportunities. Antwerp 2009 p. xii.

${ }^{239}$ Case 36/75 Rutili v Minister of the Interior [1975] ECR 1219.

${ }^{240}$ Case 43/75 Defrenne II [1976] ECR 455 and case 149/77 Defrenne III [1978] ECR 1365.

${ }^{241}$ Case 29/69 Stauder v Ulm [1969] ECR 419.

${ }^{242}$ Case 11/70 Internationale Handelsgesellschaft [1970] ECR 1125.

${ }^{243}$ Case 4/73 Nold [1974] ECR 491.

${ }^{244}$ Case 36/75 Rutili v Minister of the Interior [1975] ECR 1219.

${ }^{245}$ Case 149/77 [1978] ECR 1365.

${ }^{246}$ Case 417/85 [1987] ECR 551.
} 
respect the principle of good administration. In Dunnett, ${ }^{247}$ the ECJ stated that the European Investment Bank in a staff case was bound to consult staff representatives under a general principle of employment law before taking a decision to withdraw a benefit. In Laval $^{248}$ and Viking, ${ }^{249}$ the ECJ stated that the right to take collective action must be recognised as a fundamental right which forms an integral part of the general principles of EU law. Mia Rönnmar concludes in her contribution to the Blurring Boundaries project that despite the ECJ's declarations in Laval and Viking that the right to strike is a fundamental right in EU law, the ECJ seems to have put fundamental freedoms (free movement of services and freedom of establishment) first, and the right to industrial action second. ${ }^{250}$ In $B E C T U,{ }^{251}$ the advocate general argued that the right to paid annual leave is not only guaranteed in the Working Time Directive but also constitutes a fundamental right. In Mangold, ${ }^{252}$ the ECJ held that the principle of non-discrimination on grounds of age is a general principle of Community law. The ECJ held, under the application of the Simmenthal rationale, ${ }^{253}$ that the national court must set aside any provision of national law which may conflict with Community law, in the particular case at hand with the general principle of nondiscrimination.

\subsection{EU Charter of Fundamental Rights}

\subsubsection{Background}

According to the Preamble of the Charter, it reaffirms the rights as they result, in particular, from the constitutional traditions and international obligations common to the Member States, the ECHR, the Social Charters adopted by the Union ${ }^{254}$ and by the Council of Europe and the case law of the ECJ and of the European Court of Human Rights (ECtHR).

All EU countries are members of the United Nations, ILO and the Council of Europe. Compared to the ECHR ${ }^{255}$ the EU Charter of Fundamental Rights goes much further in protecting economic and social rights. The substantive content of the solidarity provisions in the Charter draws heavily on the Council of Europe Revised Social Charter from 1996 to which there are many references in the Explanatory remarks. All 27 EU Member States are signatories to the Revised Social Charter, but twelve ${ }^{256}$ of them have not ratified this convention and have consequently never been bound by it under public international law.

\footnotetext{
${ }^{247}$ Case T-192/99 [2001] ECR II-813, I A-65, II-313.

${ }^{248}$ Case C- 341/05, ECR I-11767.

${ }^{249}$ Case 438-05, The International Transport Workers' Federation and The Finnish Seamen's Union ECR [2007] I-10779.

${ }^{250}$ See Mia Rönnmar: Labour Law in the Courts. The Role of European Case Law on Fundamental Trade Union Rights in an Evolving EU Industrial Relations System in Ulla Neergaard, Ruth Nielsen and Lynn Roseberry (eds.): The Role of Courts in Developing a European Social Model - Theoretical and Methodological Perspectives, Copenhagen 2010.

${ }^{251}$ Case C-173/99 [2001] ECR I-4881.

${ }^{252}$ Case C-144/04 Werner Mangold v Rüdiger Helm [2005] ECR I-9981.

${ }^{253}$ Case 106/77 [1978] ECR 629.

${ }^{254}$ I.e. the Community Charter of Fundamental Rights of Workers; see above in section 7.2.2.

${ }^{255}$ The ECHR offers some protection of economic and social rights. In Airey v Ireland (Application no. 6289/73, judgment of 9 October 1979), the ECtHR stated (emphasis added): Whilst the Convention sets forth what are essentially civil and political rights, many of them have implications of a social or economic nature. The Court therefore considers, like the Commission, that the mere fact that an interpretation of the Convention may extend into the sphere of social and economic rights should not be a decisive factor against such an interpretation; there is no water-tight division separating that sphere from the field covered by the Convention.

${ }^{256}$ Austria, Czech Republic, Denmark, Germany, Greece, Hungary, Latvia, Luxembourg, Poland , Slovakia, Spain and the United Kingdom.
} 
Eight ILO Conventions have been identified by the ILO’s Governing Body as being fundamental to the rights of people at work, irrespective of levels of development of individual Member States. They are grouped into four categories:

1) Freedom of Association, ${ }^{257}$

2) Abolition of Forced Labour 258

3) Equality ${ }^{259}$

4) Elimination of Child Labour ${ }^{260}$

There is generally only scant reference to ILO conventions in EU law. That has been criticised in the literature. ${ }^{261}$ In Laval and Viking, the ECJ did, however, refer to ILO Convention 87 as a basis for considering the right to take collective action as a fundamental right. The Laval judgment has been widely criticised for tipping the balance between market freedoms and the fundamental right to take collective action in favour of market freedoms. It may be argued that the limited right to take collective action accepted by the ECJ in Laval falls short of the level of protection of the right to strike provided by ILO Convention 87. See for this view Mia Rönnmar's analysis in the Blurring Boundaries project. ${ }^{262}$ It has been suggested that in Laval the Swedish government should have invoked Article 351 FEU (ex Article 307 EC) and contended that the Swedish (and Danish) rules on strikes are necessary to comply with duties undertaken under public international law before membership of the EU and therefore according to Article 351 FEU take precedence over EU law. ${ }^{263}$

In the Charter on Fundamental Rights and the explanations referred to in the Charter that set out the sources of its provisions, there is no explicit reference to ILO conventions. The eight fundamental ILO conventions are, however, all ratified by all $27 \mathrm{EU}$ countries. Consequently they are 'international obligations common to the Member States'; see above on the ECJ's case law on fundamental rights and the Preamble to the Charter. For that reason they became more binding as a matter of EU law and not only of international law when the Lisbon Treaty entered into force 1 December 2009.

\footnotetext{
${ }^{257}$ Convention no 87, Freedom of Association and Protection of the Right to Organise Convention, 1948 and convention no 98, Right to Organise and Collective Bargaining Convention, 1949.

${ }^{258}$ Convention no 29, Forced Labour Convention, 1930 and convention no 105, Abolition of Forced Labour Convention, 1957.

${ }^{259}$ Convention no 100, Equal Remuneration Convention, 1951 and convention no 111, Discrimination (employment and Occupation) Convention, 1958.

${ }^{260}$ Convention no138, Minimum Age Convention, 1973 and convention no 182, Worst Forms of Child Labour Convention, 1999.

261 O’Higgins, Paul: Some problems of enforcement of rights under the Community Charter of Fundamental Social Rights of Workers in Vogel-Polsky, Eliane (ed): Quel avenir pour l'Europe sociale: 1992 et après?, Bruxelles 1992 p. 73.

${ }^{262}$ Mia Rönnmar: Labour Law in the Courts. The Role of European Case Law on Fundamental Trade Union Rights in an Evolving EU Industrial Relations System in Ulla Neergaard, Ruth Nielsen and Lynn Roseberry (eds.): The Role of Courts in Developing a European Social Model - Theoretical and Methodological Perspectives, Copenhagen 2010.

${ }^{263}$ See Ronnie Eklund: A Swedish Perspective on Laval, Comparative Labor Law and Policy Journal 2008 p. 551, compare Case C158/91 Levy [1993] ECR I-4287 and Case C-13/93 Minne [1994] ECR I-371 where France and Belgium successfully defended with the help of Article 351 FEU (ex Article 307 EC) their commitments under ILO Convention 89 on Night Work for Women Employed in Industry, which the ECJ later found to be contrary to the provisions of the then Equal Treatment Directive (76/207EEC).
} 


\subsubsection{Substantive Content}

There are seven chapters in the Charter: Title I. Dignity; ${ }^{264}$ Title II. Freedoms; ${ }^{265}$ Title III. Equality; ${ }^{266}$ Title IV. Solidarity; ${ }^{267}$ Title V. Citizens' Rights; ${ }^{268}$ Title VI. Justice ${ }^{269}$ and Title VII. General Provisions. The Charter contains 50 'rights, freedoms and principles without identifying which of its provisions are rights, which are freedoms and which are principles. As regards rights it is for the interpreter/for example the ECJ to decide whether they should be interpreted in accordance with the rule construction or principle construction set out above in section 7.1.3.

The Solidarity chapter in the Charter contains provisions that protect workers' right to information and consultation within the undertaking (art. 27), the right of collective bargaining and action (art. 28), right of access to placement services (art. 29), protection in the event of unjustified dismissal (art. 30), fair and just working conditions (art. 31), prohibition of child labour and protection of young people at work (art. 32), the family and professional life (art. 33), social security and social assistance (art. 34), health care (art. 35), access to services of general economic interest (art. 36), environmental protection (art. 37) and consumer protection (art. 38).

Article 53 of the Charter provides on the level of protection that nothing in the Charter shall be interpreted as restricting or adversely affecting human rights and fundamental freedoms as recognised, in their respective fields of application, by EU law and international law and by the Member States' constitutions. The Charter does thus not lower the already existing level of protection. In the EU labour law acquis, there are more extensive rights on a number of the issues covered by the solidarity provisions in the Charter. ${ }^{270}$

Assessed by its substantive content the main novelty of the Charter is Title IV on solidarity. ${ }^{271}$ Solidarity is prescribed as one of the (new) values of the EU in Article $2 \mathrm{EU}$ (post-Lisbon). Before the Lisbon Treaty solidarity was only an aim of the EU in the context of solidarity between the Member States. In the case law of the ECJ, the principle of solidarity has for years been used as a criterion for delimiting the scope of competition law. The Charter, in particular its title IV, sets out in more detail what solidarity means in an EU law context.

\footnotetext{
${ }^{264}$ This title includes: human dignity, right to life, right to integrity of the person, prohibition of torture and inhuman or degrading treatment or punishment and prohibition of slavery and forced labour.

${ }^{265}$ This title includes: right to liberty and security, respect for private and family life, protection of personal data, right to marry and right to found a family, freedom of thought, conscience and religion, freedom of expression and information, freedom of assembly and of association, freedom of the arts and sciences, right to education, freedom to choose an occupation and right to engage in work, freedom to conduct a business, right to property, right to asylum and protection in the event of removal, expulsion or extradition.

${ }^{266}$ This title includes: equality before the law, non-discrimination, cultural, religious and linguistic diversity, equality between men and women, the rights of the child, the rights of the elderly and integration of persons with disabilities.

${ }^{267}$ This title includes: workers' right to information and consultation

within the undertaking, right of collective bargaining and action, right of access to placement services, protection in the event of unjustified dismissal, fair and just working conditions, prohibition of child labour and protection of young people at work, family and professional life, social security and social assistance, health care, access to services of general economic interest, environmental protection and consumer protection.

${ }^{268}$ This title includes: right to vote and to stand as a candidate at elections to the European Parliament, right to vote and to stand as a candidate at municipal elections, right to good administration, right of access to documents, ombudsman, right to petition, freedom of movement and of residence and diplomatic and consular protection.

${ }^{269}$ This title includes: right to an effective remedy and to a fair trial, presumption of innocence and right of defence, principles of legality and proportionality of criminal offences and penalties and the right not to be tried or punished twice in criminal proceedings for the same criminal offence.

${ }^{270}$ See on the Charter and the gender equality acquis Sophia Koukoulis-Spiliotopoulos: The Lisbon Treaty and the Charter of Fundamental Rights: maintaining and developing the acquis in gender equality, European Gender Equality Law Review 2008-1.

${ }^{271}$ See for the same view Koen Lenaerts and Eddy de Smijter: A 'Bill of Rights' for the European Union, Common Market Law Review 2001 p. 273 footnote 47.
} 
If one looks only at the substantive content of the Charter, the welfare rights listed in the Charter hardly go further than the ECJ could potentially have gone on the basis of the established criteria for recognising fundamental rights in the EU. The enumeration of social rights in the Charter includes, however, some rights that have not hitherto been declared fundamental rights in the case law of the ECJ. ${ }^{272}$

\subsubsection{The Same Legal Value as the Treaties. Supremacy and Direct Effect}

Article 45 FEU and 157 FEU give rise to direct effects both in the vertical relationship against the Member States $^{273}$ and in horizontal relationships against private employers and organisations. In Walrave/Koch $v$ AUCI ${ }^{274}$ and Dona $v$ Manter, ${ }^{275}$ the ECJ ruled that Article 45 FEU gives rise to horizontal direct effect ${ }^{276}$ against associations or bodies with competence of a collective nature that do not come under public law. ${ }^{277}$ In Angonese, ${ }^{278}$ the ECJ held that direct effect of Article 39 EC also applies against individual employers.

It is generally a condition for direct effect that the provision at issue is sufficiently precise. Some of the provisions in the Charter are reasonably precise. That is, in particular the case with Article 20 on Equality before the law, the prohibition against discrimination in Article $21^{279}$ in respect of the specifically enumerated grounds, Article 24 on the rights of the child, Article $29^{280}$ on free placement services, and Article 31(2) on paid annual leave.

Under Danish labour law workers (arbejdere, in German Arbeiter) are treated less favourably than salaried employees (funktionærer, in German Angestellte) on a number of points, for example with regard to payment during paid annual leave in the Holiday Act. Since the coming into force of the Lisbon Treaty as of 1 December 2009, the question arises as to whether Articles $20^{281}$ and 31(2) on paid annual leave in the Charter have direct effect and supremacy over the Danish Holiday Act so that a Danish worker can claim the same as a salaried employee would be entitled to. In our view the answer is in the affirmative. Paid annual leave is provided for in the Working Time Directive, ${ }^{282}$ which Denmark is implementing in a way that treats workers and salaried employees differently. That is in our view a violation of Article 20 of the Charter.

\footnotetext{
272 See on that case law Koen Lenaerts and Petra Foubert: Social Rights in the Case-Law of the European Court of Justice. The Impact of the Charter of Fundamental Rights of the European Union on Standing Case-Law. Legal Issues of Economic Integration (Formerly: Legal Issues of European Integration) 2001 p. 267.

${ }^{273}$ Case 167/73 Commission v France (the Merchant Seaman's Case) [1974] ECR 359 and Case 41/74 Van Duyn v Home Office [1975] ECR 1337.

${ }_{274}$ Case 36/74 Walrave/Koch v AUCI [1974] ECR 1405. The case concerned rules of an international sporting federation.

${ }^{275}$ Case 13/76 Dona v Mantero [1976] ECR 1333. The Case concerned rules laid down by a sporting federation which is competent to control football on the territory of a Member State.

${ }^{276}$ See also Case 222/86 Heylens v UNECTEF [1987] ECR 4097.

277 See Case 36/74 Walrave and Koch [1974] ECR 1405, paragraphs 17, 18, 23 and 24; Case 13/76 Donà [1976] ECR 1333, paragraphs 17 and 18; Joined Cases C-51/96 and C-191/97 Deliège [2000] ECR I-2549, paragraph 47; Case C-176/96 Lehtonen and Castors Braine [2000] ECR I-2681, paragraph 35; Case C-309/99 Wouters and Others [2002] ECR I-1577, paragraph 120; and Case C-519/04 P Meca-Medina and Majcen v Commission [2006] ECR I-6991, paragraph 24.

${ }^{278}$ Case C-281/98 Roman Angonese v Cassa di Risparmio di Bolzano SpA [2000] ECR I-4139.

${ }^{279}$ See below in section 7.5.1.

${ }^{280}$ Article 29 on the Right of access to placement services reads: 'Everyone has the right of access to a free placement service.'

${ }^{281}$ It reads: 'All persons are equal before the law', in German 'Alle Menschen sind vor dem Gesetz gleich', which is identical with the German Grundgesetz § 3(2).

${ }^{282}$ Originally 92/104/EC, now 2003/88/EC.
} 
The German constitutional court held in $1990^{283}$ that a provision in BGB (Bürgerliches Gesetzbuch) providing for shorter periods of notice for workers (Arbeiter) than for salaried employees (Angestellte) was inconsistent with the German Grundgesetz § 3(2). ${ }^{284}$ An important factor in the development of the ECJ case law on fundamental rights has, as appears from section 2, been its link to the doctrine of the supremacy of EU law over national law and the concern of the ECJ to avoid revolt among national constitutional courts against this doctrine by elevating fundamental rights to general principles of EU law. This context makes it unlikely that the ECJ will give an interpretation to Charter provisions, as for example Article 20, that provide for a lower level of protection than the equivalent provision in the German Constitution $\S 3(2)$. This is important for the likely spread of German style fundamental rights via the Charter to countries like Denmark with a weak tradition for protection of fundamental rights in labour and welfare law.

In Zaera, ${ }^{285}$ the ECJ held that Article 151 FEU [then Article 117 EC] does not have direct effect. It also stated that the objectives of social policy laid down in Article 151 FEU are not deprived of any legal effect. They constitute an important aid, in particular for the interpretation of other provisions of the Treaty and of secondary community legislation in the social field. The ECJ has actually used Article $151 \mathrm{FEU}$ in this way. In Defrenne II, ${ }^{286}$ Article 151 FEU was relied upon to support the interpretation that equal pay between men and women must be reached by raising the lowest salaries, and in Rockfon, ${ }^{287}$ it was used to support a worker-friendly interpretation of the term 'establishment' in the Collective Redundancies Directive.

Many of the welfare provisions in the Charter are vague and for that reason likely not to be directly applicable. See for example the open end of Article 21, which prohibits discrimination on any grounds, Article 25 on the rights of the elderly, Article 34 on social security and social assistance, Article 35 on health care and Article 36 on access to services of general economic interest. Since they acquired the same value as the Treaties on 1 December 2009, they can be relied on in the same way as the ECJ has relied on Article 151 FEU [ex Article 136 EC] in the interpretation of other provisions.

\subsubsection{Field of Application of the Charter}

Fundamental rights are binding on the institutions of the EU in the exercise of their powers. Decisions have been struck down by the ECJ in staff cases for non-compliance with fundamental rights; see above on the Dunnett and Maurissen cases.

According to Article 51 of the Charter of Fundamental Rights, it is in addition to the institutions, bodies, offices and agencies of the Union also addressed to the Member States, but only when they are implementing Union law. In the Explanations to Article 51 it is stated (emphasis added) that:

As regards the Member States, it follows unambiguously from the case-law of the Court of Justice that the requirement to respect fundamental rights defined in the context of the Union is only binding on the Member States when they act in the scope of Union law (judgment of 13 July 1989, Case 5/88 Wachauf [1989] ECR 2609;

\footnotetext{
${ }^{283}$ BVerfGE 82, 126, available at http://www.oefre.unibe.ch/law/dfr/bv082126.html. See Susanne Baer: Constitutional Equality: Equality: The Jurisprudence of the German Constitutional Court, Columbia Journal of European Law 1999 p. 249.

${ }^{284}$ It reads: 'Alle Menschen sind vor dem Gesetz gleich'

${ }^{285}$ Case 126/86 [1987] p. 3697.

${ }^{286}$ Case 43-75 [1976] ECR 455.

${ }^{287}$ Case C-449/93 [1995] ECR I-4291.
} 
judgment of 18 June 1991, Case C-260/89 ERT [1991] ECR I-2925; judgment of 18 December 1997, Case C309/96 Annibaldi [1997] ECR I-7493).

In its case law, the ECJ has required Member States to respect the fundamental rights not only when they transpose an EU rule into national law, but also when they take measures that may hinder the free movement of persons, services and capital. In Carpenter, ${ }^{288}$ the ECJ thus stated that a Member State may invoke reasons of public interest to justify a national measure which is likely to obstruct the exercise of the freedom to provide services only if that measure is compatible with the fundamental rights whose observance the ECJ ensures. In support of this interpretation, it referred to $E_{R T^{289}}$ and Familiapress. ${ }^{290}$

As a result of this case law, migrant workers when exercising their right of free movement will be able to invoke the welfare rights of the Charter, even though comparable domestic workers would no be able to do this because the situation in relation to them would be purely internal. In Kremzow, ${ }^{291}$ the ECJ held that where national legislation is concerned with a situation which does not fall within the field of application of Community law, the ECJ cannot give interpretative guidance. In Vajnai, ${ }^{292}$ the problem was whether a penal provision in Hungary prohibiting the use of symbols of the international labour movement on pain of criminal prosecution was compatible with the fundamental EU law principle of non-discrimination. The question was put to the ECJ as to whether Article 6 EU, the Race Directive or Articles 10, 11 and 12 of the Charter of Fundamental Rights allow a person who wishes to express his political convictions by means of a symbol representing them to do so in any Member State. The ECJ rejected the question as inadmissible because the case concerned a purely internal situation in Hungary. Similarly, in Polier, ${ }^{293}$ the ECJ refused to answer a question about the compatibility of a French dismissal provision with the Charter $^{294}$ (and some international provisions). In 2005, the ECJ held, in Pupino, ${ }^{295}$ that fundamental rights, as general principles of law, applied not only to the scope of Community law as distinct from EU law but also to areas covered by the third pillar. The distinction between the first and third pillar was abolished by the Lisbon Treaty.

\subsection{Union Citizenship}

Since the introduction of Union Citizenship with the coming into force of the Maastricht Treaty on 1 November 1993, there has been growing emphasis in the case law of the ECJ on free movement as a fundamental right for all Union citizens irrespective of their being economically active or passive. This is particularly important in relation to the knowledge economy because the ECJ tends to regard tax-financed research and educational activities as not covered by Article 56 FEU on free

\footnotetext{
${ }^{288}$ Case C-60/00 Carpenter [2002] I-6279 paragraph 40.

${ }^{289}$ Case C-260/89 ERT [1991] ECR I-2925, paragraph 43.

${ }^{290}$ Case C-368/95 Familiapress [1997] ECR I-3689, paragraph 24.

${ }^{291}$ Case C-299/95 [1997] ECR I-2629.

${ }^{292}$ Case C-328/04 [2005] I-8577.

${ }^{293}$ Case 361/07, not reported, available in French at the ECJ website curia.europa.eu.

${ }^{294}$ The question was: [L]'ordonnance 2005-893 [...], qui autorise le licenciement du salarié pendant la période de consolidation de deux ans, prévue par le [CNE], sans indiquer la légitimité de la rupture et [...] sans information préalable au regard du droit européen, tel que défini dans la charte des droits fondamentaux [de l’Union européenne], qui précise [...] le droit des travailleurs à ne pas être licencié sans motif valable, [est-elle valide?]

${ }^{295}$ Case C-105/03 [2005] ECR I-5285.
} 
movement of services. In her contribution to the Blurring Boundaries project, Eleanor Spaventa ${ }^{296}$ assesses the constitutional impact of Union citizenship at both national and EU level. ${ }^{297}$ She begins by noting that most of the scholarship on Union citizenship has centred on the significance of the rights to move and reside guaranteed by Article 21 FEU. Before the introduction of Union citizenship, Member State nationals needed to establish both a cross border link and an economic activity to claim the rights to move and reside in another Member State. After the introduction of Union citizenship, the citizen can claim these rights regardless of economic contribution - the only requirement is that the migrant citizen crosses or intends to cross a border. By virtue of crossing a border, migrant citizens can claim the right to equal treatment in relation to rules which limit entitlement to welfare benefits. As a result, any residence requirements now fall within the scope of the Treaty and must be justified. ${ }^{298}$

In Humbel, ${ }^{299}$ the ECJ held that courses taught in a technical institute that forms part of the secondary education provided under the national education system cannot be regarded as services within the meaning of the then Article 49 EC [now Article 56 FEU], properly construed. In Wirth, ${ }^{300}$ the ECJ held that courses given in an establishment of higher education financed essentially out of public funds do not constitute services within the meaning of the then Article 49 EC [now Article 56 FEU]. The ECJ is, however, willing to use Article 21 FEU (former Article 18 EC) on free movement for Union citizens to complement Article 56 FEU. In Schwartz, ${ }^{301}$ it thus held that where taxpayers of a Member State send their children to a school established in another Member State, the services of which are not covered by the then Article 49 EC [now Article 56 FEU], Article 18 EC [now Article 21 FEU] precludes legislation which allows taxpayers to claim as special expenses conferring a right to a reduction in income tax the payment of school fees to certain private schools established in national territory, but generally excludes that possibility in relation to school fees paid to a private school established in another Member State.

In Bressol, ${ }^{302}$ the ECJ held that Articles 18 and 21 FEU preclude national legislation which limits the number of students not regarded as resident in Belgium who may enrol in medical and paramedical courses at higher education establishments, unless the referring court, having assessed all the relevant evidence submitted by the competent authorities, finds that that legislation is justified in the light of the objective of protection of public health. The competent authorities may not rely on Article 13(2)(c) of the International Covenant on Economic, Social and Cultural Rights, adopted by the United Nations in 1966, see above in section 7.2.1, if the referring court holds that the decree of the French Community of 16 June 2006 which regulates the number of students in certain programmes in the first two years of undergraduate studies in higher education is not compatible with Articles 18 and 21 FEU.

\footnotetext{
${ }^{296}$ Eleanor Spaventa: The Constitutional Impact of Union Citizenship in Ulla Neergaard, Ruth Nielsen and Lynn Roseberry (eds.): The Role of Courts in Developing a European Social Model - Theoretical and Methodological Perspectives, Copenhagen 2010.

${ }^{297}$ See also Michael Dougan: The Constitutional Dimension to the case law on Union citizenship, European Law Review 2006 p. 613.

${ }^{298}$ See Gareth Davies: Any Place I Hang my Hat? or: Residence is the New Nationality, European Law journal 2005 p. 43.

${ }^{299}$ Case C-263/86 Humbel [1988] ECR 5365.

${ }^{300}$ Case C-109/92, Wirth [1993] ECR I-6447.

${ }^{301}$ Case 366/04 Schwarz [2005] ECR I-10139.

${ }^{302}$ Case C- 73/08 Bressol judgment of 13 April 2010.
} 


\subsection{Non-Discrimination}

\subsubsection{The Historical Development}

When Denmark entered the EC on 1 January 1973, the protection against discrimination was very weak in Danish law. There was, for example, no equal pay or equal treatment legislation relating to any ground of discrimination. Equal pay for men and women was provided for in some but not all collective agreements. It was lawful for an employer to dismiss a pregnant woman on grounds of pregnancy. There was no statutory prohibition against racial or ethnic discrimination in the labour market. Due to a preference for collective bargaining over statutory regulation, ${ }^{303}$ the Nordic (parliamentary) legislator has been somewhat reluctant to fulfil international obligations fully in the field of labour law. Until 1996, it was for example still arguable that Danish private employers under domestic Danish law were legally free to take racist employment decisions, though Denmark ratified the United Nations Convention on the Elimination of All Forms of Racial Discrimination (CERD) in 1971; see on the dualist approach to public international law and the concomitant tradition of majoritarian, parliamentary democracy in Denmark above in section 7.1.1.

In spite of this weak legal protection against discrimination, Denmark was (and still is) often seen as being among the countries in the world with the highest level of equality, not least gender equality. Danish women are among those who have the highest employment rate for women in the world. Roseberry has argued that Scandinavian women owe their privileged position in the world more to their countries' social welfare policies than to laws addressing sex discrimination in the labour market. ${ }^{304}$

The EU has pursued a strong non-discrimination agenda since the 1970's and has, at EU level, given high priority to anti-discrimination. In the period from 1970's-1999 (the coming into force of the Amsterdam Treaty), there were only EU provisions on non-discrimination on grounds of nationality and sex, and as far as gender was concerned mainly in employment and occupation. After 2000, broader bans on discrimination on a number of grounds and in other areas, including goods and services have been adopted. Direct or indirect discrimination on grounds of nationality is mainly relevant in connection with free movement on the internal market; see above in sections 4-6. The present section deals (mainly) with discrimination on other grounds than nationality. The concept of indirect discrimination underlying the free movement provisions in the Treaty has, however, provided the framework for the conceptual development in other areas of discrimination law; see below in section 7.5.2.

Gender discrimination law is one of the oldest and most developed parts of EU labour law. ${ }^{305}$ In 1957, the then EC Treaty contained only one single provision (Article 119 EEC Treaty, now Article 157 FEU) on gender discrimination, namely the principle of equal pay between men and women for work of equal value. Since the 1970's, a large number of directives prohibiting discrimination have

\footnotetext{
${ }^{303}$ Niklas Bruun, Boel Flodgren, Håkan Hydén, Marit Halvorsen and Ruth Nielsen: The Nordic Labour Relations Model, Dartmouth 1992.

${ }^{304}$ Roseberry, Lynn: Equal Rights and Discrimination Law, in Scandinavian Studies in Law Volume 43, Stability and Change in Nordic Labour Law, Stockholm 2002 p. 215.

${ }^{305}$ For a critical analysis in a comparative perspective of the law in this field, see Roseberry, Lynn: The Limits of Employment Discrimination Law in the United States and European Community, Copenhagen 1999 and Beryl Philine ter Haar, Paul Copeland: What are the Future Prospects for the European Social Model? An Analysis of EU Equal Opportunities and Employment Policy, European Law Journal 2010 p. 273. See also the publications from the Commission's Network of legal experts on the gender equality directives at http://ec.europa.eu/social/main.jsp?catId=641\&langId=en.
} 
been adopted. Until 2000 they only dealt with gender discrimination and were limited in scope to employment and occupation. Most of the gender-related directives in regard to employment and occupation have now been repealed and replaced with the recast directive on gender equality in the labour market. ${ }^{306}$ Recasting of the gender directives is aimed at clarification and bringing together in a single text the main provisions of the sex equality directives. For a part also some case law of the ECJ is incorporated. The ECJ has played an important role in the field of equal treatment between men and women, in ensuring that individuals can effectively invoke and enforce their right to gender equality. Similarly, it has delivered important judgments interpreting the EU equality directives and Article 157 FEU (ex Article 141 EC/119 EEC) on equal pay. ${ }^{307}$

The adoption of the Amsterdam Treaty 1997, which entered into force on 1 May 1999 marked a turning point in the development of EU discrimination law. The Amsterdam Treaty introduced important innovations. It incorporated the requirement of mainstreaming gender equality in Article 8 FEU (ex Article 3(2) EC). It also introduced Article 19 FEU (originally Article 13 EC), which became the legal basis for an expanded anti-discrimination regime prohibiting discrimination not only on grounds of gender but also on grounds of ethnic origin, religion, age, handicap and sexual orientation. $^{308}$

The EU Charter of Fundamental Rights contains provisions on equality in chapter III. Article 20 on Equality before the law provides that 'Everyone is equal before the law'; see on the possible consequences of this provision above in section 7.3.3. Article 21 in the Charter on Nondiscrimination provides:

1. Any discrimination based on any ground such as sex, race, colour, ethnic or social origin, genetic features, language, religion or belief, political or any other opinion, membership of a national minority, property, birth, disability, age or sexual orientation shall be prohibited.

2. Within the scope of application of the Treaty establishing the European Community and of the Treaty on European Union, and without prejudice to the special provisions of those Treaties, any discrimination on grounds of nationality shall be prohibited.

Cultural, religious and linguistic diversity is protected in Article 22. Article 23 provides that equality between men and women must be ensured in all areas, including employment, work and pay. The principle of equality shall not prevent the maintenance or adoption of measures providing for specific advantages in favour of the under-represented sex. Article 24 deals with the rights of the child.

\footnotetext{
306 2006/54/EC.

${ }^{307}$ See Kilpatrick, Claire: Gender Equality: A Fundamental Dialogue in Silvana Sciarra (ed.): Labour Law in the Courts: National Judges and the ECJ, London 2001.

${ }^{308}$ See the ethnic equality directive 2000/43/EC, the framework employment directive 2000/78/EC and the gender equality, goods and services directive 2004/113/EC, which were enacted on this legal basis.
} 


\subsubsection{Basic Concepts}

The central discrimination concepts are laid down in the respective directives and are often the subject of further interpretation by the ECJ. The following concepts are used in all the equality directives: ${ }^{309}$

- Direct discrimination occurs '(...) where one person is treated less favourably on grounds of sex or one of the other protected grounds than another is, has been or would be treated in a comparable situation.'

- Indirect discrimination occurs '(...) where an apparently neutral provision, criterion or practice would put persons of one sex or a person affected by one of the other protected grounds at a particular disadvantage compared with persons of other groups, unless that provision, criterion or practice is objectively justified by a legitimate aim, and the means of achieving that aim are appropriate and necessary.'

- Instruction to discriminate on grounds of a person's sex or one of the other protected grounds is in EU law equated with discrimination.

- Harassment occurs '(...) where unwanted conduct related to the sex, ethnic origin, age, etc. of a person occurs with the purpose or effect of violating the dignity of a person, and of creating an intimidating, hostile, degrading, humiliating or offensive environment.'

- Sexual harassment occurs '(...) where any form of unwanted verbal, non-verbal or physical conduct of a sexual nature occurs, with the purpose or effect of violating the dignity of a person, in particular when creating an intimidating, hostile, degrading, humiliating or offensive environment.'

As a rule, direct discrimination is prohibited unless a specific exception applies, such as that the sex of the person concerned is a determining factor for the job, for example a male character in a film has to be a man. Indirect discrimination is prohibited, unless it is objectively justified. If one applies Alexy's terminology set out above in section 7.1.4., direct discrimination follows the rule construction, indirect discrimination the principle construction.

Indirect discrimination is concerned with the effects of a certain treatment and takes into account everyday social realities. For instance, less favourable treatment of part-time workers will often amount to indirect discrimination against women because most part-time employees are women. Compared to the case of direct discrimination, the possibilities for justification of indirect discrimination are much broader. The current definition of indirect discrimination was first laid down in the Ethnic Equality Directive. In the proposal for that directive, ${ }^{310}$ the Commission refers to the definition developed in ECJ in Flynn. ${ }^{311}$

Harassment and sexual harassment include the violation of a person's dignity and the creation of an intimidating, hostile, degrading, humiliating or offensive environment. The main difference is that in case of harassment on grounds of a person's sex, the person is ill-treated because he or she is

\footnotetext{
${ }^{309}$ See the Ethnic Equality Directive (2000/43/EC) Article 2, the Employment Framework Directive (2000/78/EC) Article 2, the Recast Gender Equality (Employment and Occupation) Directive (2006/54/EC) Article 2, and the Gender Equality (Goods and Service) Directive (2004/113EC) Article 2.

${ }^{310}$ COM (99)566.

${ }^{311}$ Case C-237/94 Flynn [1996] I-2617.
} 
a woman or a man. In the case of sexual harassment, it rather involves a person being subject to unwelcome sexual advances or, for instance, that the behaviour of the perpetrator aims at obtaining sexual favours. The prohibition against harassment on grounds of sex has an equivalent in prohibitions against harassment on grounds of racial or ethnic origin, religion or belief, disability, age or sexual orientation.

The measures permitted as positive action provisions aim at eliminating or counteracting the detrimental effects on women/ethnic groups etc. which arise from existing attitudes, behaviour and structures based on the idea of a traditional division of roles in society.

\subsubsection{Invoking EU Law against Danish Law before Danish Courts}

The answer to the research questions of the Blurring Boundaries regarding the impact of EU law on the Danish welfare state depends on how the general rules on the relationship between EU law and national law operate in Denmark in welfare matters. In matters of welfare law, gender equality law is the area that has been most intensely integrated into national litigation.

The enforcement system in Danish labour law/gender equality law is divided into a part where claims are based on parliamentary legislation or individual contracts and a collective labour law part where claims are based on a collective agreement (social partner legislation). If the matter is governed by a provision in a collective agreement, a case can be brought before an industrial arbitration tribunal or the Labour Court by the trade union which is party to the collective agreement. Individual workers cannot bring a case before industrial arbitrations/the Labour Court but must leave that to the trade union which is party to the collective agreement. Claims based on parliamentary legislation or individual contracts can be brought by the individual workers/employees concerned before the ordinary courts. In practice that is most often done by the trade union of which the worker/employee ${ }^{312}$ is a member on behalf of and with the consent of the individual worker/employee. Most trade unions pay the cost of the cases (as part of the service they offer their members in return for the membership fees) and handle the cases on behalf of their members if they so wish. If the individual worker/employee can afford it and so wishes, he or she can bring the case on his/her own without asking the trade union. If a case is covered by a collective agreement and the trade union which is party to the collective agreement chooses to pursue the case through the collective labour law system (i.e. the Labour Court or arbitration tribunals), the case cannot be brought before the ordinary courts. Discrimination claims that can be brought before the ordinary courts can also be brought before the Equality Complaints Board, which treats the case free of charge, i.e. paid by the tax-payers. After the case has been decided by the Complaints Board, it may be brought before the ordinary courts if one of the parties is unwilling to accept the ruling of the Complaints Board.

The burden of proof provisions in the underlying EU directives ${ }^{313}$ have been implemented in Denmark and are used in both the collective labour law part of the enforcement system and by the

\footnotetext{
${ }^{312}$ In a comparative perspective the level of unionisation, i.e. the proportion of the workforce that is member of a trade union, is high in Denmark, at around 75-80 \%.

${ }^{313}$ See Article 8 in the Ethnic Equality Directive (2000/43/EC), Article 10 in the Employment Framework Directive (2000/78), Article 9 in the Gender Equality (Goods and Service) Directive (2004/113EC) and Article 19 in the Recast Gender Equality (Employment and Occupation) Directive (2006/54/EC).
} 
ordinary courts. For instance, a worker/employee (represented by her trade union) won an equal pay case before the Supreme Court recently because the employer could not lift his burden of proof. ${ }^{314}$

Marlene Wind argues ${ }^{315}$ that Nordic courts prefer to solve as many EU-related judicial disputes as possible without referring preliminary questions under Article $267 \mathrm{FEU}$ and that the distinction between majoritarian and constitutional democracies may help understanding why majoritarian, parliamentary democracies express greater scepticism towards supranational judicial review. She does not distinguish between different areas of law. In regard to welfare law, gender equality law is one of the areas where the judicial dialogue between Danish courts and the ECJ has been most intense and where a number of the general principles of EU law have been put into practice in Danish case law. In this area of law, Danish courts and industrial tribunals are not particularly reluctant to refer preliminary questions to the ECJ. Claire Kilpatrick ${ }^{316}$ has undertaken a comparative analysis of the judicial dialogue which over the years has been conducted between the ECJ and the courts in 6 EU Member States: Denmark, France, Germany, Italy, Spain and the United Kingdom on gender equality law. She divides the 6 Member States under examination into three pairs according to their level of preliminary reference activity. The most active pairs is Germany and the UK, followed by France and Denmark, who referred later, less and on fewer issues. Spain and Italy make up an inactive pair with no decided references on January 1, 2001.

Denmark implemented the EU prohibition against age and disability discrimination in 2004. Since then, some Danish questions on interpreting the bans on age ${ }^{317}$ discrimination have also been referred to the ECJ.

Danish trade unions in the Confederation of Trade Unions (Danish LO) were unwilling to invoke EU law before Danish courts and industrial tribunals until the mid 1980s even though they lost equal pay cases in Danish industrial arbitration tribunals, in particular the Vejle Amts Folkeblad ${ }^{318}$ and the Danfoss-I cases, ${ }^{319}$ on grounds of provisions in collective agreements which were rather obviously in contravention of the underlying EU rules prohibiting indirect sex discrimination and consequently invalid, had EU law been properly applied. ${ }^{320}$ By the mid 1980s, a trade union with more than $80 \%$ women members broke the consensus about abstaining from using EU law and

\footnotetext{
${ }^{314} \mathrm{U} 2009.2993 \mathrm{H}$.

${ }^{315}$ Marlene Wind: The Nordics, the EU and the Reluctance Towards Supranational Judicial Review, Journal of Common Market Studies, 2010 and Marlene Wind, Dorte Sindbjerg Martinsen and Gabriel Pons Rotger: The Uneven Legal Push for Europe Questioning Variation when National Courts go to Europe, European Union Politics No 4, 2008. See for a criticism of this view Niels Fenger: Om danske domstoles relative tilbøjelighed til at forelægge præjudicielle spørgsmål for EU-domstolen, Juristen 2009 No 9.

${ }^{316}$ Kilpatrick, Claire: Gender Equality: A Fundamental Dialogue in Sciarra, Silvana (ed.), Labour law in the courts - National judges and the European Court of Justice, Oxford, 2001.

${ }^{317}$ See case C-499/08 Ole Andersen v Region Syddanmark pending. In this case the plaintiff argues that section 2a of the Danish Salaried Employees Act is incompatible with the Framework Employment directive (2000/78/EC), which Denmark in his view has failed to implement correctly.

${ }^{318}$ HK v Dansk Arbejdsgiverforening/Danske Dagblades Forenings Forhandlingsorganisation for Vejle Amts Folkeblad, Arbitral Award of 11.2.1985. Summary in Danish in Andersen, Agnete, Ruth Nielsen og Kirsten Precht, Ligestillingslovene med kommentarer, Kbhvn. 2010.

${ }^{319}$ In Denmark Danfoss-I: HK v DA for Danfoss A/S, Arbitral Award of 16.4.1985. Summary in Danish in Andersen, Agnete, Ruth Nielsen og Kirsten Precht: Ligestillingslovene med kommentarer, Kbhvn 2010.

${ }^{320}$ See for details Nielsen, Ruth, Equality in Law between Men and Women in the European Community. Denmark, The Hague, 1995. See also Roseberry, Lynn: Equal Rights and Discrimination Law, in Scandinavian Studies in Law Volume 43, Stability and Change in Nordic Labour Law, Stockholm 2002 p. 215.
} 
brought the Danfoss case, ${ }^{321}$ in which it demanded that questions should be referred to the ECJ to test the compatibility of the Danish judicial practice with EU law. The outcome was that the earlier Danish practice was overturned. This case marked a breakthrough in Danish trade union attitudes to support claims based on EU law. Since Danfoss, EU law has successfully been invoked against Danish law in a number of cases. ${ }^{322}$ In Danfoss, the ECJ ruled that where an undertaking applies a pay system which is characterised by a total lack of transparency, the burden of proof is on the employer to show that his wage practice is not discriminatory where a female worker establishes, by comparison with a relatively large number of employees, that the average pay of female workers is lower than that of male workers. Sophisticated statistical calculations are thus unnecessary to shift the burden of proof. A calculation of average pay is sufficient. This judgment not only changed Danish law but also paved the way for a further development of EU law. The ECJ's ruling in Danfoss was codified in the Burden of Proof Directive, which is now repealed and replaced by the recast Directive on Gender Equality in the labour market. ${ }^{323}$

The majority of cases in Denmark related to equal treatment are about pregnancy, maternity, paternity and parental leave. In Pedersen, ${ }^{324}$ the ECJ struck down the pregnancy provisions of the Danish Salaried Employees Act and the Danish practice of granting only benefit (and not full pay) as compensation for absence from work due to pregnancy-related illness in situations when absence from work due to other illnesses resulted in an entitlement to full pay. It also found that it is contrary to the Equal treatment Directive and the Pregnancy Directive ${ }^{325}$ for national legislation to provide that an employer may send home a woman who is pregnant, although not unfit for work, without paying her salary in full when he considers that he cannot provide work for her. Following this judgment the Danish Salaried Employees Act was amended in 1999 thus changing the legal position for the future. In an arbitral award in the Glasfiber case, ${ }^{326}$ the chairman used the ruling in Pedersen in a Danish case where pregnant workers working in a dangerous working environment were sent home without full pay. The employer operated an industrial plant producing mill wings while using dangerous chemical substances including carcinogens. It was the practice of the employer to send pregnant workers home once it became known they were pregnant. It was undisputed that the pregnant workers were not unfit for work, but their working environment was unsuitable for pregnant workers. The employer did not try to adjust the working conditions or to move the workers to alternative non-dangerous work. The workers received no wages from the employer but benefit from the municipality under the Benefit Act. It follows from Article 5 of the pregnancy directive that, when there is a risk to the safety or health of a pregnant worker or the foetus, the employer shall take the necessary measures to ensure that, by temporarily adjusting the working conditions and/or the working hours of the worker concerned, the exposure of that worker

\footnotetext{
321 Case C-109/88 Handels-og-Kontorfunktioncerernes Forbund i Danmark v Dansk Arbejdsgiverforening (acting for Danfoss) [1989] ECR 3199. The Danish arbitral award in the case is in Denmark usually called Danfoss-II: HK v DA for Danfoss A/S, Arbitral Award of 22. 10.1991. Summary in Danish in Andersen, Agnete, Ruth Nielsen og Kirsten Precht: Ligestillingslovene med kommentarer, Kbhvn 2010.

${ }^{322}$ See Nielsen, Ruth: Europeanization of Nordic Labour Law, Scandinavian Studies in Law Volume 43, Stability and Change in Nordic Labour Law, Stockholm 2002 p. 37.

${ }^{323}$ 2006/54/EC.

${ }^{324}$ Case C-66/96 Høj Pedersen and others v Fællesforening for Danmarks Brugsforeninger (FDB) and others [1998] ECR I-7327.

${ }^{325}$ Directives 76/207/EEC on Equal Treatment and 92/85/EEC (the Pregnancy Directive).

${ }^{326}$ Arbitral Award of 21.10.1999, CO-industry for SID v DI for LM Glasfiber A/S.
} 
to such risks is avoided. If the adjustment of her working conditions and/or working hours is not technically and/or objectively feasible, or cannot reasonably be required, the employer shall take the necessary measures to move the worker concerned to another job. If moving her to another job is not technically and/or objectively feasible or cannot reasonably be required, the worker concerned shall be granted leave for the period necessary to protect her safety or health. The chairman in the Glasfiber industrial arbitration case held that since there were no provisions on the sending home and payment of pregnant workers in a situation such as that with which the case was concerned in the collective agreement nor in national legislation, the interpretation of the underlying directives should be applied to the individual employment contracts. Since the sending home was caused by the dangerous character of the place of work and the assessment of the situation exercised by the employer, it followed in the view of the arbitration chairman from the interpretation of the ECJ in Pedersen that an employer who sent home pregnant workers who were not unfit for work had to pay them full wages.

In Tele Denmark, ${ }^{327}$ the ECJ held that the Equal Treatment Directive and the Pregnancy Directive are to be interpreted as precluding a worker from being dismissed on the ground of pregnancy:

- where she was recruited for a fixed period,

- she failed to inform the employer that she was pregnant even though she was aware of this when the contract of employment was concluded,

- and because of her pregnancy she was unable to work during a substantial part of the term of that contract.

The principle of consistent interpretation, i.e. the duty of national courts and tribunals to interpret national law in accordance with EU law is by and large respected in Denmark including in labour law cases where there is non-conformity between Danish law and EU law. In a case before industrial arbitration on interpretation of a collective agreement ${ }^{328}$ on the question whether it is a violation of Article $157 \mathrm{FEU}$ that women on pregnancy/parental leave were disregarded in connection with local wage negotiations, the arbitration tribunal held - referring to the ECJ judgment in Gillespie $e^{329}$ - that women irrespective of the wording of the relevant collective agreement and the joint understanding of the parties of this agreement were entitled to wage increases.

Generally Denmark strives to implement directives correctly, but on a few occasions the ECJ has held that Denmark had failed to implement a welfare-related directive correctly. In the Ambi case, ${ }^{330}$ the ECJ held that Article 33 of the Sixth VAT Directive ${ }^{331}$ precludes the introduction or maintenance of a tax of the same type as the Danish employment market contribution. In an infringement case against Denmark on equal pay, ${ }^{332}$ the ECJ held that Denmark had failed to

\footnotetext{
${ }^{327}$ Case C-109/00 Tele Danmark [2001] ECR I-6993.

${ }^{328}$ HK/Industri for SS v Grafisk Arbejdsgiverforening for Nysted Bogtrykkeri A/S arbitration award of 2.10.2003.

${ }^{329}$ Case C-342/93 Gillespie [1996] ECR I-475.

${ }^{330}$ Case C-200/90 Dansk Denkavit ApS and P. Poulsen Trading ApS v Skatteministeriet [1992] ECR I-2217.

331 77/388/EEC.

${ }^{332}$ Case 143/83 Commission v Denmark [1985] ECR 427.
} 
implement the (then) Equal Pay Directive ${ }^{333}$ correctly following which Denmark amended the Danish Equal Pay Act.

\subsection{Preliminary Conclusions}

The multi-level constitution of the European Social Model puts constraints on the Danish legislator in that it deprives it of its prior role as highest authority and source of legitimacy and subjects it to control by the ECJ. Denmark began its membership of the EU with a very low level of antidiscrimination protection and has had to raise this level to comply with the minimum standards set by EU law.

At EU level, EU law guarantees fundamental rights at a level that at least are as high as the German standard of fundamental rights (Grundrechte) and accords all EU citizens directly applicable fundamental rights with supremacy over their national law. In particular in gender equality cases EU law has successfully been invoked against Danish law.

\section{Guaranteeing Services of General Economic Interest}

The terms 'services of general interest' (hereinafter referred to as 'SGIs') and 'services of general economic interest' (hereinafter referred to as 'SGEIs') have in recent years become of increasing political and academic interest. ${ }^{334}$ They are normally considered related to the more common terms 'public services' and 'welfare services' known from everyday speech, and thereby constitute rather central concepts as to the theme of this paper.

The concept SGI was for long not mentioned in the Treaty itself. In the Services Directive, it is mentioned in Recital 17, but not in any of the actual provisions. In addition, it is mentioned in various Communications from the Commission. Due to these reasons, amongst others, it has been reasonable not to consider it as a legal concept as such. However, the entering into force of the Treaty of Lisbon has changed this, as it is stated in Protocol 26 that the high contracting parties wish to emphasise the importance of SGIs. The concept truly came to the fore of Community law when the Commission adopted the Communication carrying the title 'Services of general interest in Europe' in $1996 .{ }^{335}$ The concept is often considered as a general concept containing SGEIs and 'non-economic services of general interest' (hereinafter 'NESGIs') as subgroups. ${ }^{336}$ The element

\footnotetext{
333 75/117/EEC, now repealed and replaced by the recast Gender Equality Directive (Employment and Occupation, 2006/54/EC).

334 The present Section 8 largely (but not exclusively) builds on the following works of Ulla Neergaard: Services of General Economic Interest: The Nature of the Beast, in Markus Krajewski, Ulla Neergaard \& Johan van de Gronden (eds.): The Changing Legal Framework for Services of General Interest in Europe. Between Competition and Solidarity, T. M. C. Asser Press, 2009, pp. 17-50; Privilegerede virksomheder, in Caroline Heide-Jørgensen, Simon Evers Hjelmborg, Jan Magne Langseth, Ulla Neergaard, Sune Troels Poulsen, Charlotte Friis Bach Ryhl, Jens Schovsbo \& Peter Stig Jacobsen: Konkurrenceretten i EU, DJØF Publishing, 2009, 3. ed.; and Services of General (Economic) Interest: What Aims and Values Count?, in Ulla Neergaard, Ruth Nielsen \& Lynn Roseberry (eds.): Integrating Welfare Functions into EU Law - From Rome to Lisbon, DJØF Publishing, 2009. Related are also papers presented at conferences in the UK which will be published as: Services of General Economic Interest under EU law Constraints, in Dagmar Schiek, Ulrike Liebert \& Hildegard Schneider (eds.): European Economic and Social Constitutionalism after the Treaty of Lisbon (forthcoming); and: SGEIs: The Commission Soft Law and Legislative Approach Including the Treaty of Lisbon, in Erika Szyszczak, Jim Davies, Mads Andenas \& Tarjei Bekkedal (eds.): Developments in Services of General Interest (forthcoming);

${ }^{335}$ Commission of the European Communities: Services of general interest in Europe (96/C281/03), OJ C281/3, 26.09.1996.

${ }^{336}$ Concerning the understanding of the concept NESGIs and for a more detailed account of the other concepts of relevance, see Ulla Neergaard: Services of General Economic Interest: The Nature of the Beast, in Markus Krajewski, Ulla Neergaard \& Johan van de Gronden (eds.): The Changing Legal Framework for Services of General Interest in Europe. Between Competition and Solidarity, T. M. C. Asser Press, 2009, pp. 17-50.
} 
'general' may be considered to indicate the public's interest that the service in question is provided. Page finds that the terms 'general interest' and 'public interest' are identical. ${ }^{337}$ Thus, a service or benefit offered only to certain undertakings or economic sectors is not likely to be considered as being of "general" interest. ${ }^{338}$ The public interest will normally be of a non-economic nature, as the final object will be of a social, cultural or similar nature. ${ }^{339}$ Pursuant to the Commission, traditional criteria for the determination of 'general interest' are: universality, transparency, continuity, and accessibility, but this is to some degree contestable. ${ }^{340}$

The concept SGEI is from a legal point of view much more important. It certainly constitutes a legal concept, because it is included in the wording of Article 106(2) FEU (ex Article 86(2) EC). Importantly, it is also a central element within Article 14 FEU (ex Article 16 EC). In Protocol 26 of the Treaty of Lisbon, it is also inherent. Finally, it is worth mentioning that it plays a central role in the demarcation of the scope of the Services Directive. ${ }^{341}$ Generally, the term seems to refer to "market services" with certain specific characteristics. Other possible areas that have been mentioned are water distribution services, water supply services, waste water services, treatment of waste or public radio and television services. More specifically, it is worth noting that the Court of First Instance (now the General Court) in the BUPA case regarding SGEIs found that the provision of the service in question must, by definition, assume a general or public interest, implying that SGEIs are distinguished from services in the private interest, even though that interest may be more or less collective or be recognised by the State as legitimate or beneficial. ${ }^{342}$ Furthermore, it is explained that the general or public interest on which the Member State relies must not be reduced to the need to subject the market concerned to certain rules or the commercial activity of the operators concerned to authorisation by the State. ${ }^{343}$ In other words, the ECJ states that the mere fact that the national legislature, acting in the general interest in the broad sense, imposes certain rules of authorisation, functioning or control on all the operators in a particular sector does not in principle mean that there is a SGEI. ${ }^{344}$ The Services Directive contains a certain contribution to an understanding of this central term. Thus, it may be understood that SGEIs may consist of services in the postal sector, electricity sector, gas sector, water distribution services, water supply services, waste water services, and treatment of waste. ${ }^{345}$ Also, it may be understood that such services may exist in the field of transport. ${ }^{346}$ Furthermore, it may be understood that these are services provided for economic consideration ${ }^{347}$ and may only be considered to be a SGEI if they are provided in

\footnotetext{
${ }^{337}$ A. C. Page: Public Undertakings and Article 90, European Law Review (1982) p. 28.

338 José Luis Buendia Sierra: Exclusive Rights and State Monopolies under EC Law. Article 86 (formerly Article 90) of the EC Treaty, Oxford University Press, 1999, p. 279.

${ }^{339}$ Ibid. 278.

${ }^{340}$ Commission of the European Communities: Commission Staff Working Document. Annexes to the Communication from the Commission on Social services of general interest in the European Union - Socio-economic and legal overview - COM(2006) 177 final, 26.04.2006, SEC(2006) 516, Section 3.1.

${ }^{341}$ For the sake of completeness, reference should also be made to Article 36 of the - so far in principle still unbinding - Charter of Fundamental Rights of the European Union.

${ }^{342}$ Case T-289/03, British United Provident Association Ltd (BUPA), BUPA Insurance Ltd, BUPA Ireland Ltd v. Commission of the European Communities, Judgment of the Court of First Instance, 12 February 2008, para. 178.

343 Ibid. para. 178.

${ }^{344}$ Ibid. para. 178.

${ }^{345}$ The Services Directive, Article 17.

${ }^{346}$ The Services Directive, Recital 17.

${ }^{347}$ The Services Directive, Recital 17.
} 
application of a special task in the public interest entrusted to the provider by the Member State concerned. ${ }^{348}$ Finally, it is understood that services may only be considered as such services if the assignment is made by way of one or more acts, the form of which is determined by the Member State concerned and should specify the precise nature of the special task. ${ }^{349}$

In what follows in this Section 8, firstly the development of the Treaty texts will be touched upon (Section 8.1.). In addition, the soft law will be included to look for an improved understanding (Section 8.2.). ${ }^{350}$ Here, the soft law in focus is limited to Commission Communications on SGEIs and related concepts. Finally, the case law of the ECJ will be included (Section 8.3.). ${ }^{351}$ All three sources will be examined from an evolutionary point of view in order to trace more exactly the contours of the transformation which is likely to have taken place. On this basis, certain preliminary conclusions are stated (Section 8.4.).

\subsection{The Development in the Treaties}

In what follows, a fairly quick glance is taken at the Treaty texts beginning with a look taken at the Treaty of Rome, continuing with a look taken at the Treaty of Amsterdam and the Treaty of Lisbon. The Treaty of Maastricht and the Treaty of Nice are not of direct relevance here, and thus are not dealt with.

\subsubsection{The Treaty of Rome}

The birthmarks of the EU as to be found with the establishment of the original European Economic Community pursuant to the Treaty of Rome, which entered into force on 1 January 1958, were - as the name itself already indicates - largely only of an economic character. The focus was primarily on economic integration. This original premise should, however, not be viewed as being identical to a premise of a market economic ideology always to rule. Especially Article 90 EEC (later on Article 86 EC and now Article 106 FEU) - which necessarily must be of particular interest here - should be seen as not completely allowing for solely a market economic ideology to prevail. ${ }^{352}$ This provision

\footnotetext{
${ }^{348}$ The Services Directive, Recital 70.

349 The Services Directive, Recital 70. Compare for instance with Case C-280/00 Altmark Trans GmbH and Regierungspräsidium Magdeburg v. Nahverkehrsgesellschaft Altmark GmbH, and Oberbundesanwalt beim Bundesverwaltungsgericht [2003] ECR I-77477; and Case T-17/02 Fred Olsen, SA v. Commission of the European Communities [2005] ECR II-2031, paras. 186-191, concerning conditions regarding an assignment and paras. 199-203 concerning the specification of the special task. Also see Commission Decision of 28 November 2005 on the application of Article 86(2) of the EC Treaty to State aid in the form of public service compensation granted to certain undertakings entrusted with the operation of services of general economic interest (2005/842/EC) OJ L 312 , 29/11/2005, Recital 8.

${ }^{350}$ As SGEIs stand in the centre of the analysis, sector-specific regulation and related soft law is not included here, as only the soft law of a more horizontal character is put under scrutiny. Also, e.g. soft law related to state aid and public procurement is not taken into consideration.

${ }^{351}$ Pursuant to Article 19 EU, the terminology regarding the European courts now is: "The Court of Justice of the European Union shall include the Court of Justice, the General Court and specialised courts...” This terminology is used throughout the present Chapter, also in situations of reference to case law rendered before the entering into force of the Lisbon Treaty. Therefore, what has often been referred to as the European Court of Justice will here be referred to as the Court of Justice. Also, an analysis of judgments from other courts of relevance is not systematically included, as it is considered sufficient to limit the analysis to judgments from the highest court in the hierarchy.

${ }^{352}$ In this regard, see also Cosmo Graham: Essential Facilities and Services of General Interest, Diretto e Politiche dell’Unione Europea, 2007, p. 29, who sums up how Prosser distinguishes between two models in EU law for the treatment of public services, deriving from different values. Thus, the first model takes the view that public service is best undertaken through market based mechanisms, implying that the normal provisions of competition law are applied, whereas the second model takes the view that the values of public service are perceived as threatened by competition law.
} 
had the following wording which - with the exception of the numbering of the provisions which are referred to - is in principle unaltered until today:

"1. In the case of public undertakings and undertakings to which Member States grant special or exclusive rights, Member States shall neither enact nor maintain in force any measure contrary to the rules contained in this Treaty, in particular to those rules provided for in Article 7 and Articles 85 to 94 [later on Articles 12 and 81-89 EC and now Articles 18 and 101-109 FEU].

2. Undertakings entrusted with the operation of services of general economic interest or having the character of a revenue-producing monopoly shall be subject to the rules contained in this Treaty, in particular to the rules on competition, in so far as the application of such rules does not obstruct the performance, in law or in fact, of the particular tasks assigned to them. The development of trade must not be affected to such an extent as would be contrary to the interests of the Community.

3. The Commission shall ensure the application of the provisions of this Article and shall, where necessary, address appropriate directives or decisions to Member States."

Regarding SGEIs, Article 90 EEC (later on Article 86(2) EC and now Article 106(2) FEU) is naturally of central importance. ${ }^{353}$

\subsubsection{The Treaty of Amsterdam}

In the Treaty of Amsterdam, which entered into force 1 May 1999, Article 7D EC (later on Article $16 \mathrm{EC}$, and now Article $14 \mathrm{FEU}$ ) was launched with the following wording:

"Without prejudice to Articles 77, 90 and 92 [later on Articles 73, 86, and 87 EC, and now Articles 93, 106, and 107 FEU], and given the place occupied by services of general economic interest in the shared values of the Union as well as their role in promoting social and territorial cohesion, the Community and the Member States, each within their respective powers and within the scope of application of this Treaty, shall take care that such services operate on the basis of principles and conditions which enable them to fulfil their missions.” 354

It is noteworthy that the provision was inserted in the beginning of the Treaty concerning principles, rather than close to what has now become Article $106 \mathrm{FEU}$. It is generally viewed as a rather ambiguous provision. ${ }^{355}$ In addition, mention should be made of Declaration 13 to Article 7D (later on Article 16 EC and now Article 14 FEU), in which it is stated that:

"The provisions of Article 7D of the Treaty establishing the European Community on public services shall be implemented with full respect for the jurisprudence of the Court of Justice, inter alia as regards the principles of equality of treatment, quality and continuity of such services.”

Some Member States had actually wanted a change of what was still designated as Article 90 EC (later on Article 86 EC and now Article 106 FEU), but the Commission - most likely supported by

\footnotetext{
${ }^{353}$ Regarding the interpretation thereof, see Section 4 below.

${ }^{354}$ Concerning this provision, see among others the Commission: Report to the Laeken European Council. Services of General Interest, $\operatorname{COM}(2001)$ 598, p. 17, and the following pages; Walter Frenz: Dienste von algemeinem wirtschaftlichen Interesse, Europarecht, 2000, pp. 901-925; Malcolm Ross: Article 16 E.C. and services of general interest: from derogation to obligation?, European Law Review, 2000, pp. 22-38; and Erika Szyszczak: Public Service Provision in Competitive Markets, Yearbook of European Law, 2001, pp. 62-64.

${ }^{355}$ See e.g. Wolf Sauter: Services of general economic interest and universal service in EU Law, European Law Review, 2008, p. 172.
} 
some other Member States - was strongly against this. The result of the negotiations only became the insertion of Article 7D EC (later on Article 16 EC and now Article 14 FEU). ${ }^{356}$ As expressed by Duff, there is probably no more stark exposure in the Treaty of the division between those who wish to regulate to protect public utilities and the like, and those who wish to make them competitive, than indicated in this provision. ${ }^{357}$ It may be mentioned that the Commission has - however unsuccessfully - worked on the insertion of a new paragraph in the "old" Article 3 EC concerning SGIs. ${ }^{358}$

\title{
8.1.3. The Treaty of Lisbon
}

The Treaty of Lisbon entered into force on 1 December 2009. It contains several elements of interest to the present analysis which will therefore be introduced in what follows.

Firstly, it is noteworthy that Article 86 EC once again has survived in an unchanged version ${ }^{359}$ this time in the Treaty on the Functioning of the European Union. It is renumbered as Article 106 FEU. Secondly, Article 16 EC has been altered to the following - however having been renumbered Article 14 FEU:

\begin{abstract}
"Without prejudice to Article 4 of the Treaty on European Union or to Articles 93, 106 and 107 of this Treaty, and given the place occupied by services of general economic interest in the shared values of the Union as well as their role in promoting social and territorial cohesion, the Union and the Member States, each within their respective powers and within the scope of application of the Treaties, shall take care that such services operate on the basis of principles and conditions, particularly economic and financial conditions, which enable them to fulfil their missions. The European Parliament and the Council, acting by means of regulations in accordance with the ordinary legislative procedure, shall establish these principles and set these conditions without prejudice to the competence of Member States, in compliance with the Treaties, to provide, to commission and to fund such services.”
\end{abstract}

The last sentence constitutes a completely new addition. Previously in the legislative history of the provision, this sentence had been suggested formulated in what then was Article III-6 as: "European laws shall define these principles and conditions". ${ }^{360}$ The wording in the final version must be viewed as a much softer legal basis. Nevertheless, as has been put forward by Sauter, the change

\footnotetext{
${ }^{356}$ See José Luis Buendia Sierra: Exclusive Rights and State Monopolies under EC Law. Article 86 (formerly Article 90) of the EC Treaty, Oxford University Press, 1999, p. 330, and the following. Also see Commission: Services of general interest in Europe (96/C281/03), Sections 71-74; and Leo Flynn: Competition Policy and Public Services in EC Law after the Maastricht and Amsterdam Treaties, in David O’Keeffe \& P. Tworney (eds.): Legal Issues of the Amsterdam Treaty, Hart Publishing, 1999, pp. 196197.

${ }^{357}$ A. Duff: The Treaty of Amsterdam. Text and Commentary, Federal Trust, 1997, p. 84.

${ }^{358}$ Commission: Services of general interest in Europe (96/C281/03), Sections 71-74.

${ }^{359}$ This is except for the renumbering of the provisions, which it refers to.

${ }^{360}$ Also see e.g. Julio Baquero Cruz: Services of General Interest and EC Law, in Grainne de Búrca (ed.): EU Law and the Welfare State. In Search of Solidarity, Oxford University Press, 2005, p. 178; Christopher Bovis: Financing Services of General Interest in the EU: How do Public Procurement and State Aids Interact to Demarcate between Market Forces and Protection?, European Law Journal, 2005, p. 81; Commission: Communication from the Commission to the European Parliament, the Council, the European Economic and Social Committee and the Committee of the Regions. White Paper on services of general interest, COM(2004) 374, p. 12; Dragana Damjanovic \& Bruno de Witte: Welfare Integration through EU Law: The Overall Picture in the Light of the Lisbon Treaty, in Ulla Neergaard, Ruth Nielsen \& Lynn Roseberry: Integrating Welfare Functions into EU Law - From Rome to Lisbon, DJØF Publishing, 2009, p. 86 and the following; Stéphane Rodrigues: Vers une loi européenne des services publics, Revue du Marché commun et de l’Union européenne, 2003, pp. 503-512; Erika Szyszczak: Legal Tools in the Liberalisation of Welfare Markets, in Ulla Neergaard, Ruth Nielsen \& Lynn Roseberry (eds.): Integrating Welfare Functions into EU Law - From Rome to Lisbon, Djoef Publishing, 2009, p. 294 and the following; and Sybe de Vries: Tensions within the Internal Market. The Functioning of the Internal Market and the Development of Horizontal and Flanking Policies, Europa Law Publishing, 2006, pp. 161 and 381.
} 
implies that in future we will have two competing, or concurrent, legal bases for legislation on SGEIs, namely a new one in Article 14 FEU based on co-decision between the European Parliament and the Council, and one for Commission directives in Article 86(3) EC as before, however renumbered. ${ }^{361}$

Thirdly, reference should also be made to one of the protocols annexed to the Lisbon Treaty. Number 26 explicitly concerns SGEIs, and it is stated that the High Contracting Parties wish to emphasise the importance of these. ${ }^{362}$ Article 1 stipulates that:

\begin{abstract}
"The shared values of the Union in respect of services of general economic interest within the meaning of Article 16 EC Treaty include in particular: - the essential role and the wide discretion of national, regional and local authorities in providing, commissioning and organizing services of general economic interest as closely to the needs of the users; - the diversity between various services of general economic interest and the differences in the needs and preferences of users that may result from different geographical, social or cultural situations; - a high level of quality, safety and affordability, equal treatment and the promotion of universal access and of user rights.”
\end{abstract}

Article 2 stipulates that:

"The provisions of the Treaties do not affect in any way the competence of Member States to provide, commission and organise economic services of general interest.”

As has been put forward by Sauter, although the fact that it was felt necessary to adopt this Protocol highlights the deep concerns held by the Member States that something essential may slip from their control on this issue, in reality the Protocol might appear not to add much of substance as regards SGEIs themselves. ${ }^{363}$

Finally, it should be mentioned that pursuant to Article 6 of the FEU, the Union recognises the rights, freedoms and principles set out in the Charter of Fundamental Rights of the European Union of 7 December 2000, as adapted at Strasbourg, on 12 December 2007, which shall have the same legal value as the Treaties. Thus, with the Lisbon Treaty having entered into force, the legal effect of the Charter has changed significantly. Therefore, Article 36 - placed in Title IV on "Solidarity" thereof should be mentioned. ${ }^{364}$ In this provision, it is stated that:

“The Union recognises and respects access to services of general economic interest as provided for in national laws and practices, in accordance with the Treaty establishing the European Community, in order to promote the social and territorial cohesion of the Union.” 365

\footnotetext{
${ }^{361}$ Wolf Sauter: Services of general economic interest and universal service in EU Law, European Law Review, 2008, p. 172.

${ }^{362}$ Regarding the origin of this Protocol, see among others Appendix 3 of Conseil Economique et Social, Analysis of the implications of the Lisbon Treaty on Services of General Interest and proposals for implementation, Discussion paper drawed up by European experts, 2008; and D. C. le Bihan \& A. Moriceau: Services d'intérêt économique general et valeurs communes, Revue du Marché commun et de l’Union europénne, Number 519, 2008, p. 358.

${ }^{363}$ Wolf Sauter: Services of general economic interest and universal service in EU Law, European Law Review, 2008, p. 173.

${ }^{364}$ Regarding the interpretation of this provision, see in particular Julio Baquero Cruz: Services of General Interest and EC Law, in Grainne de Búrca (ed.): EU Law and the Welfare State. In Search of Solidarity, Oxford University Press, 2005, p. 178. Also see in opposite direction Romano Prodi, who in a speech concerning Services of general economic interest and the European model of development, SPEECH/03/63, CEEP dinner, Brussels, 05.02.2003, p. 4, expresses that: "The Charter of Fundamental Rights explicitly recognises the citizenship dimension of services of general interest. It makes access to such services a fundamental right.”

${ }^{365}$ For the sake of completeness, reference may also be made to two additional provisions in the Charter, namely Article 34, which deals with social security and social assistance, and Article 35, which deals with health care.
} 


\subsection{The Development of the Commission's "Soft Law"}

The purpose of this section is to provide an overview of the Commission's initiatives over the years to SGEIs. The weight is given to the soft law, which may be understood as: "Rules of conduct that are laid down in instruments which have not been attributed legally binding force as such, but nevertheless may have certain (indirect) legal effects, and that are aimed at and may produce practical effects." 366 In more practical terms, what will be examined are the various communications launched by the Commission.

This development was initiated in 1996, where the Commission for the first time in a coherent manner sets out its position on the subject. - This happens in the Communication entitled: Services of general interest in Europe. Here the Commission states that it had felt that "....it was time to reaffirm the principles of its policies and set out its objectives for the future”. ${ }^{367}$ The instrument is not given any designation as such, but it may probably be classified as a communication. ${ }^{368}$ It contains the following headlines (sub-sections are excluded from mentioning): Introduction; Definition of terms; I. Services of general interest: a key element in the European model of society; II. The Community contribution: Dynamism, Flexibility and Solidarity; and III. Objectives for the future.

A few years later, namely in 2000, the Commission adopted a communication in this field again. ${ }^{369}$ The document in question was this time entitled: Communication from the Commission. Services of general interest in Europe. ${ }^{370}$ It is stated that the communication has the purpose of updating the communication from 1996. ${ }^{371}$ It contains the following general sections (sub-sections and annexes are excluded from mentioning): 1. Introduction; 2. The mission of services of general interest; 3. Services of general interest and the single market; 4. Experience with the liberalisation of certain services of general interest; and 5. A European perspective.

\footnotetext{
${ }^{366}$ Linda Senden: Soft Law in European Community Law, Hart Publishing, 2004, p. 112, whom also at p. 23 points out that: “The designation as soft law of instruments such as recommendations, notices, resolutions, conclusions, guidelines, declarations, programmes, codes of practice etc is induced by the fact that they can all be typified as Community legal instruments that have not been attributed legally binding force...”. Also see e.g. U. Mörth: Soft Law and New Modes of EU Governance - A Democratic Problem?, Paper presented in Darmstadt November 2005; Linda Senden: Soft law and its implications for institutional balance in the EC, Utrecht Law Review, 2005, Vol. 1, Issue 1, pp. 79-99; and Linda Senden: Soft Law, Self-Regulation and Co-Regulation in European Law: Where Do They Meet?, Electronic Journal of Comparative Law, 2005, Vol. 9.1.

${ }^{367}$ Ibid., Introduction.

${ }^{368}$ The Commission refers to it as a communication e.g. at:

http://europa.eu/legislation summaries/other/l26087 en.htm. Linda Senden: Soft Law in European Community Law, Hart Publishing, 2004, p. 132, states the following about communications of interest here: “...[C]ommunications are far from homogenous and they do not play an unequivocal role in the Community law system.” The author, at p. 133, distinguishes between three types of communications, namely: 1 . Inter-institutional communications; 2. purely informative communications; and 3. Individual communications.

${ }^{369}$ See COM(2000) 580.

${ }^{370}$ See generally about the instrument “communications” above.

${ }^{371}$ In the later Green Paper on Services of General Interest, COM(2003) 270, p. 4, see below, the Commission states that the update of the 2000-communication was made with the “...view to increasing the legal certainty for operators as regards the application of competition and internal market rules to their activities”. In the 2000-communication itself, it is stated in Section 6 that the aims are: “...- to provide further clarification on the respective roles of different levels of public authorities and of the competition and internal market provisions applied to services of general interest in order to respond to the request for greater legal certainty on the part of operators. Of special concern is the field of application of the rules on State aid, - to further develop the European framework relating to the good functioning of services of general interest, in which local, regional and national authorities as well as the Community have their role to play, in line with Article 16 of the EC Treaty."
} 
The Nice European Council meeting in 2000 took note of this latter communication, but requested the Commission to report further on the implementation of these services for the Laeken European Council in 2001. Consequently, the Commission adopted a report on 27 October 2001. ${ }^{372}$ As a response to a request of the Barcelona European Council, the Commission prepared a short communication containing a status of the work on the examination of a proposal for a framework directive on SGIs. ${ }^{373}$

In addition, in 2003, the Commission launched a debate on the role of the European Union in promoting the provision of high quality SGIs on the basis of a Green Paper. ${ }^{374}$ This document was given the title: Green paper on services of general interest. ${ }^{375}$ It contains the following general sections (sub-sections, summary table and annex are excluded from mentioning): Introduction; 1. Background; 2. The scope of Community action; 3. Towards a Community concept of services of general interest?; Good governance: organisation, financing and evaluation; 5. Services of general interest and the challenge of globalisation; and 6. Operational conclusion. Altogether, 30 questions were submitted for discussion.

Then in 2004, a White Paper on the subject came. ${ }^{376}$ The title of this document became: Communication from the Commission to the European Parliament, the Council, the European Economic and Social Committee and the Committee of the Regions. White Paper on services of general interest. The Commission states about the aim thereof that: "In line with the request made by the European Parliament in its Resolution on the Green Paper of 14 January 2004 [footnote omitted], the Commission draws its conclusions from the debate in the present White Paper.” 377 Also, it states that:

\footnotetext{
${ }^{372}$ See COM(2001) 598.

373 Commission: Communication from the Commission to the Council, the European Parliament, the Economic and Social Committee and the Committee of the regions on the Status of Work on the Examination of a Proposal for a Framework Directive on Services of General Interest, $\operatorname{COM}(2002) 689$.

${ }^{374}$ See COM(2003) 270.

${ }^{375}$ According to Linda Senden: Soft Law in European Community Law, Hart Publishing, 2004, p. 124, the following may be said about Green Papers in general: “Green Papers are instruments used solely by the Commission, and their use dates back to the early 1980s. Since then, but in particular since 1993, the use of Green Papers has steadily increased... The Green Papers usually start with an overview of the present situation and regulatory framework in a particular area and then identify the problems and challenges in this respect. On the basis thereof, the need for future action is analysed and options or suggestions for action are presented. However, as yet these are not specific and do not contain concrete proposals. According to the Commission, Green Papers are 'reflection documents for discussion, [footnote omitted] drafted with a view to public debate and consultation... Over the last decade, it has become more of a habit to formulate specific questions in the Green Papers, to which the addressees are called upon to respond, but other comments remain equally welcome of course... Their adoption must therefore be seen against the background of the preparation and further development of Community law and policy. As such, the Green Paper can be typified as a preparatory instrument and said to fulfil a pre-law function in the Community law context.”

${ }^{376}$ See COM(2004) 374. According to Linda Senden: Soft Law in European Community Law, Hart Publishing, 2004, p. 125, the following may be said about White Papers in general: "Subsequent to the consultation process, the Commission often draws up a communication on the follow-up to be given to the Green Paper. [Footnote omitted] Sometimes, this follow-up consists of the presentation of a White Paper. [Footnote omitted] Both of these documents give information on the outcome of the debate on the Green Paper.” At pp. 126-127, it is added: "White Papers are also an instrument only of the Commission. They are less frequently adopted than Green Papers... This makes clear that White Papers serve a twofold objective. On the one hand, they constitute documents for discussion and consultation; on the other, they also aim at laying down the main lines or strategy of action for the future. To this end, they usually contain concrete proposals for action. Depending on which of the two aspects is emphasized, White Papers may actually differ quite considerably; some White Papers are more directed towards debate, whereas others may already contain (detailed) work programmes or timetables for action. [Footnote omitted] For the same reasons as given above in respect of Green Papers, White Papers can be typified as preparatory instruments, or, instruments that fulfil a pre-law function. But, generally speaking, White Papers often go a step further than Green Papers, in that they contain (concrete) proposals.

${ }^{377}$ Ibid., p. 3. Here, it is also, among others, explained that the Commission staff has prepared a Report on the public consultation which analyses the contributions submitted and provides background material to the present White Paper.
} 
"By submitting this White Paper, the Commission does not intend to conclude the debate that has developed at European level. Its aim is to make a contribution to the ongoing discussion and to take it further by defining the Union's role and a framework that allows these services to function properly. The White Paper sets out the Commission's approach in developing a positive role for the European Union in fostering the development of highquality services of general interest and presents the main elements of a strategy aimed at ensuring that all citizens and enterprises in the Union have access to high-quality and affordable services. The document focuses on just some of the key issues of the debate as it would be impossible to address all the issues raised during the public consultation. More specific issues will be addressed in the context of the relevant policies.” 378

The White Paper contains the following general sections (sub-sections and annex are excluded from mentioning): 1. Introduction; 2. A shared responsibility of Public Authority in the Union; 3. Guiding principles of the Commission's approach; 4. New Orientations for a Coherent policy.

Finally, in 2007, the Commission adopted a package of initiatives to turn its Citizens' Agenda into a consistent set of actions, which among others included a Communication on: Services of general interest, including social services of general interest: a new European Commitment. ${ }^{379}$ The aim of this communication is stated to be: $:^{380}$

\begin{abstract}
"The agreement by Heads of State and Government of a Protocol on services of general interest to be annexed to the Treaty of Lisbon is a decisive step towards establishing a transparent and reliable EU framework. The new Treaty on the Functioning of the European Union will also include a new Article 14 stressing the joint responsibility of the Union and the Member States and establishing a legal basis for the EU to take action. These new provisions build on a decade of debate about the responsibilities of the EU and about whether or not the EU should adopt an overarching framework for services of general interest. This debate has helped to generate converging views on the role and approach of the EU with regard to services of general interest, in particular following the 2004 Commission's White Paper [Footnote omitted] and the 2006 opinion of the Parliament [Footnote omitted]. A broad agreement has emerged on the need to ensure legal certainty and consistency across EU policies, while respecting the diversity of sectors and situations. There is also broad recognition of the need to improve general awareness and understanding of EU rules. By spelling out the role of the Union, the Protocol brings the necessary clarity and certainty to EU rules. This Communication presents the Commission's views on this debate, in particular in the light of the Parliament's resolution and the Treaty of Lisbon. It also draws on the public consultation on social services of general interest initiated in 2006."
\end{abstract}

The general structure of the communication is the following (sub-sections are excluded from mentioning): 1. Introduction; 2. The role of the EU: ensuring common rules while respecting diversity; 3. The Protocol: a coherent framework for EU action; 4. Moving forward; and 5. Conclusion.

\footnotetext{
${ }^{378}$ Ibid., p. 4.

${ }^{379}$ See Commission, Communication from the Commission to the European Parliament, the Council, the European Economic and Social Committee and the Committee of the Regions. Accompanying the Communication on "A single market for $21^{\text {st }}$ century Europe”. Services of general interest, including social services of general interest: a new European commitment, COM(2007) 725. One other document included in the package may be mentioned, namely: Commission, Commission Staff Working Document. Progress since the 2004 White Paper on services of general interest, SEC(2007) 1515.

${ }^{380}$ See generally about the instrument "communications" above.
} 


\subsection{The Case Law of the ECJ}

The focus in this part of Section 9 is to examine the interpretation of Article 106(2) FEU (ex Article 86(2) EC) by the ECJ in order to gain a better understanding of SGEIs in this context. As is widely known, the internal market law rules have for a long time been read as implicating a balance between free movement and alternative national aims, e.g. as expressed in Article 36 FEU (ex Article 30 EC) or the Cassis de Dijon-justification, which often may be viewed as allowing for interests, which are social - in a broad sense - in character. Thus, among others due to this, it is of interest to analyse how the SGEIs have been dealt with by the ECJ in the context of competition law rules, especially Article 106 FEU (ex Article 86 EC), in order to see if any indications are to be found here regarding the balancing between economic and other aims and values. The understanding of Article 106 FEU (ex Article 86 EC) by the ECJ can to a certain degree constitute some guidance as to the future shaping of SGEIs at the political level.

In the case law, Article 106(2) FEU (ex Article 86(2) EC) has primarily played the role of a kind of exemption to the combined reading of Articles 106(1) and 102 FEU (ex Articles 86(1) and 82 EC), and the following analysis is mainly limited to the interpretation of Article 106(2) FEU (ex Article 86(2) EC) in this context. ${ }^{381}$ Here, the ECJ has rather often viewed the granting of exclusive rights and related issues as contrary to these provisions unless justified primarily under reference to Article 106(2) FEU (ex Article 86(2) EC). The guiding principle is the so-called Höfner criterion, which implies that national measures which create a situation in which an undertaking cannot avoid infringing Article 102 FEU (ex Article 82 EC) are incompatible with the Treaty. ${ }^{382}$ An author like Buendia Sierra has stated that: "Therefore, all exclusive rights are in principle contrary to Article 86(1) and 82 [now Articles 106(1) and 102 FEU] unless they can be justified for the general interest reasons and they respect the principle of proportionality". ${ }^{383}$ Others are more sceptical as to the scope of the combined reading. For instance, Maillo states that: “...there is no automatic abuse, nor can the grant of an exclusive right be considered to be prima facie illegal..." 384 Under all circumstances, the pressure from the EU put on national measures on especially exclusive and special rights has increased severely since the nineties. The underlying rationale behind this development seems to be driven by a market economic ideology. ${ }^{385}$ Therefore, the possibility of justification pursuant to Article 106(2) FEU (ex Article 86(2) EC) has grown in importance, and it

\footnotetext{
${ }^{381}$ For the sake of completeness, it should be mentioned that Article 106(2) FEU (ex Article 86(2) EC) could possibly also have a role to play with regard to other Treaty provisions, which already follows from the term "in particular" included in the wording of the provision, indicating that the reference to the competition provisions is probably not exhaustive.

382 Judgment of 23 April 1991 in Case C-41/90, Klaus Höfner and Fritz Elser v Macroton GbmH, Para. 27.

383 José Luis Buendia Sierra: Exclusive Rights and State Monopolies under EC Law. Article 86 (formerly Article 90) of the EC Treaty, Oxford University Press, 1999, p. 189.

384 Jerónimo Maillo: Article 86 EC. Services of General Interest and EC Competition Law, in Giuliano Amato \& Claus-Dieter Ehlermann (eds.): EC Competition Law. A Critical Assessment, Hart Publishing, 2007, p. 624. See for the same perception also e.g. Sybe de Vries: Tensions within the Internal Market. The Functioning of the Internal Market and the Development of Horizontal and Flanking Policies, Europa Law Publishing, 2006, p. 158. Also see a possible support for this point of view, e.g. Judgment of 23 May 2000 in Case C-209/98, Entreprenørforeningens Affalds/Miljøsektion (FFAD) v Københavns Kommune, Paras. 67-69.

${ }^{385}$ See further Ulla Neergaard: Public Service Concessions and Related Concepts - the Increased Pressure from Community Law on Member States' Use of Concessions, Public Procurement Law Review, 2007, pp. 387-409; and Modernising Article 82 EC - with Particular Focus on Public and Otherwise Privileged Undertakings, Europarättslig Tidsskrift, 2007, pp. 54-82. Regarding the related provisions, it is noteworthy that the Court of Justice recently has stated that: “... Article 86(1) EC precludes Member States, in the case of public undertakings and undertakings to which they grant special or exclusive rights, from maintaining in force national legislation contrary to Articles 43 EC and 49 EC”, which pursuant to the judgment includes concessions granted without prior public procedure. See Judgment of 17 July 2008 in Case C-347/06, ASM Brescia SpA v Comune di Rodengo Saiano, Para. 61.
} 
is of interest to analyse how the balance between the more market economic ideological approach pursuant to Article 106(1) FEU (ex Article 86(1) EC) is contrasted with Article 106(2) FEU (ex Article 86(2) EC), apparently allowing for other aims and values to count.

More precisely, in what now follows, firstly a few introductory remarks about the exemption are made. ${ }^{386}$ Then, a synthesis of what may be deducted from an analysis of the judgments of relevance is put forward.

\title{
8.3.1. Generally about Article 106(2) FEU (ex Article 86(2) EC)
}

This provision has given reason to great interpretational difficulties, or, as it has been explained by Baquero Cruz:

\begin{abstract}
"When judges were first confronted with Article 86(2) [now Article 106(2) FEU], a provision unprecedented in other legal systems, it was certainly difficult to find operational and legal tests that reflected the economic ideas underlying that provision. And it remains difficult, at present, to devise a legal test that grants the necessary margin of action to political institutions without leaving the rules underenforced or unenforced.” 387
\end{abstract}

In principle, the importance of the provision lies in the possibility of an otherwise unlawful national measure being considered as legal. At the same time, an activity which has been legitimised by such a measure, or the like, may also in this way find its "immunity".

Article 106(2) FEU (ex Article 86(2) EC) had not been given importance by the ECJ until the nineties. In this context, Buendia Sierra explains that the originally very restrictive interpretation of the prohibitions of Article 37 and Article 106(1) FEU (ex Articles 31 and Article 86(1) EC) made the exemption contained in Article 106(2) FEU (ex Article 86(2) EC) almost superfluous. ${ }^{388}$ The reason was that if exclusive rights and related legal constructions were not, in general, prohibited there was no need for an exemption. Since the interpretation of Article 106(1) FEU (ex Article 86(1) EC) now has severely changed, the importance of Article 106(2) FEU (ex Article 86(2) EC) obviously also has changed.

The underlying conflict which Article 106(2) FEU (ex Article 86(2) EC) may be seen as relating itself to may be expressed with the words of the Commission:

"The real challenge is to ensure smooth interplay between, on the one hand, the requirements of the single European
market and free competition in terms of free movement, economic performance and dynamism and, on the other, the
general interest objectives. This interplay must benefit individual citizens and society as a whole. This is a very

\begin{abstract}
${ }^{386}$ The provision contains several legal concepts of great importance, which, however, will not be defined here, as the available amount of space does not allow this. Concepts of relevance are especially "undertakings", "entrustment”, "revenue-producing monopoly", "particular tasks", "development of trade", "interests of the Community". Ordinary textbooks on competition law will often contain an analysis of these. Regarding "services of general economic interest", I have already above in footnote 4 made reference to some of the literature of relevance. The concept "obstruct" will be of central interest in the analysis of the case law below, i.e. in Section 4.2.1.1. Other details as to the application of the provision are out of the same reason left out here.

${ }^{387}$ Julio Baquero Cruz: Beyond Competition: Services of General Interest and European Community Law, in Gráinne de Búrca (ed.): EU Law and the Welfare State. In Search of Solidarity, Oxford University Press, 2005, p. 171. Also see e.g. Malcolm Ross: Article 16 E.C. and services of general interest: from derogation to obligation?, European Law Review, 2000, p. 23, whom has a similar message, as he states: "As is well documented, [Footnote omitted] the interpretation of this provision has produced a long line of complex and at times abstruse case law, with difficulties being encountered in relation to virtually all its aspects.”

${ }^{388}$ José Luis Buendia Sierra: Exclusive Rights and State Monopolies under EC Law. Article 86 (formerly Article 90) of the EC Treaty, Oxford University Press, 1999, p. 273, and the following.
\end{abstract}


tricky balancing act, since the goalposts are constantly moving: the single market is continuing to expand and public services, far from being fixed, are having to adapt to new requirements.” 389

The way in which the ECJ so far has met this challenge is the focus of what follows.

\subsubsection{Synthesis of What May be Deducted From the Case Law}

The following synthesis of what may be deducted from an analysis of the case law is divided into two parts, where the first explains the analytical framework applied by the ECJ, and the second contains an examination of the character of the exemption.

\section{The Analytical Framework Used by the ECJ}

In a decision as to whether Article 106(2) FEU (ex Article 86(2) EC) can imply "immunity" to an otherwise unlawful anti-competitive state measure or activity legitimised by such a measure, the ECJ will often apply a two-step-test, possibly supplemented by a third and/or fourth step: ${ }^{390}$ Thus, the ECJ might follow the following pattern of argumentation:

whether a "service of general economic interest" is entrusted;

whether the application of the rules on competition obstructs the performance, in law or in fact, of the particular tasks assigned to the undertaking(s);

whether the principle of proportionality in the strict sense - pursuant to which it shall be examined whether a less anti-competitive measure could reach the same result - is fulfilled;

whether the development of trade is not affected to such an extent as would be contrary to the interests of the Community.

It should be emphasised that this is only meant to constitute a simplified picture of the scheme of thinking, which the ECJ is likely to use, however, not necessarily. In other words, derogations may occur, especially because this field of law is still under development, and it is therefore characterised by a relatively high degree of uncertainty and unpredictability.

The steps are applied cumulatively, so that they all in principle should be answered in the positive as a condition for "immunity". The individual step should thus only be applied if the examination of the previous step leads to a positive result. In many cases the examination ends after the first two steps. In case the answer to the examination under the second step is in the positive, the rules of competition will not be applicable in order to condemn the measure in question, etc., unless the ECJ finds it necessary to examine the third or the fourth step, which may lead to another result. However, neither the third nor the fourth step is applied that often, but if applied and the answers to the involved questions are in the negative, the measure, etc., will be condemned. ${ }^{391}$

\footnotetext{
${ }^{389}$ The Commission's first communication on the subject: Commission of the European Communities, Services of General Interest in Europe (86/C281/03), Para. 19.

${ }^{390}$ As a condition for applying the test, it is inter alia assumed that an undertaking in the sense of Article 106(2) FEU (ex Article 86(2) EC) is involved.

${ }^{391}$ For a further account of the framework, see e.g. the following works of Ulla Neergaard: Services of General Economic Interest under EU law Constraints, in Dagmar Schiek, Ulrike Liebert \& Hildegard Schneider: European Economic and Social Constitutionalism after the Treaty of Lisbon (forthcoming); Privilegerede virksomheder, in Konkurrenceretten i EU, DJØF Publishing, 2009, 3. ed., with Caroline Heide-Jørgensen, Simon Evers Hjelmborg, Jan Magne Langseth, Sune Troels Poulsen,
} 


\section{The Character of the Exemption}

It may be asked what kind of legitimate interests may justify an exemption pursuant to Article 106(2) FEU (ex Article 86(2) EC). As a point of departure, it is the nature of the provision that the legitimate interest which may be invoked is the assurance that those particular tasks which have been entrusted one or several privileged undertakings are performable.

Besides this observation, it may be noted that the ECJ is seldom very explicit in its application of this element. Often the examination becomes blurred with the examination of whether a "service of general economic interest" is involved. This impression is gained from e.g. expressions such as "the task of general interest" ${ }^{392}$ or "justified by a task of a public service of general economic interest". ${ }^{393}$ The same impression may be gained from a case like GT-Link, where the ECJ states that: 'It does not follow, however, that the operation of any commercial port constitutes the operation of a service of general economic interest or, in particular that all the services provided in such a port amount to such a task.' ${ }^{394}$ In a case like Almelo, the ECJ is more explicit than usual regarding the definition of the particular task. Thus, here it is specified that the involved undertaking must ensure that throughout the territory in respect of which the concession is granted, all consumers, whether local distributors or end-users, receive uninterrupted supplies of electricity in sufficient quantities to meet demand at any given time, at uniform tariff rates and on terms which may not vary save in accordance with objective criteria applicable to all customers. ${ }^{395}$

It might be that in certain newer cases, it is possible to detect a certain tendency towards also more independently of the concept SGEIs and "particular tasks" to include "other interests". In principle, it might be that interests such as public health, public security, or the environment could be invoked in themselves. A certain support for such a possibility could for instance be said to be found in the Dutch Electricity Monopoly Case, where interest in ensuring the supply of electricity on the basis of costs that are as low as possible and in a socially responsible manner is somehow touched upon. ${ }^{396}$ In the French Gas- and Electricity Monopoly Case, the interest in, among others, the continuity of supply and equal treatment between customers or consumers could seem to be given weight. ${ }^{397}$ Furthermore, it may be mentioned that in Corsica Ferries France the interest in the safety in port waters seems to be of importance. ${ }^{398}$ Also, it may be mentioned that e.g. in Albany, which is one of the judgments in the September Trilogy, the ECJ states that the supplementary

\footnotetext{
Charlotte Friis Bach Ryhl, Jens Schovsbo \& Peter Stig Jacobsen; and Services of General (Economic) Interest: What Aims and Values Count?, in Ulla Neergaard, Ruth Nielsen \& Lynn Roseberry (eds.): Integrating Welfare Functions into EU Law - From Rome to Lisbon DJØF Publishing, 2009.

392 Judgment of 11 April 1989 in Case 66/86, Ahmed Saeed and Silver Line Reisebüro GmbH v Zentrale zur Bekämpfung unlauteren Wettbewerb e. V., Para. 57.

${ }^{393}$ Judgment of 13 December 1991 in Case C-18/88, Régie des télégraphes et des téléphones v GB-Inno-BM SA, Para. 22.

394 Judgment of 17 July 1997 in Case C-242/95, GT-Link A/S v De Danske Statsbaner (DSB), Para. 52.

395 Judgment of 27 April 1994 in Case C-393/92, Gemeente Almelo and Others v Energibedrijf Ijsselmij NV, Para. 48.

${ }^{396}$ Judgment of 23 October 1997 in Case C-157/94, Commission of the European Communities v Kingdom of the Netherlands, Para. 63. Further, it is pointed out in the subsequent Para. 64: "In view of the foregoing and, in particular, the fact that the Court has not accepted the legal approach on which both the Commission's reasoned opinion and its application were based, the Court is not in a position, in these proceedings, to consider whether, by granting exclusive import right to SEP, the Kingdom of the Netherlands in fact went further than was necessary to enable that establishment to perform, under economically acceptably conditions, the tasks of general economic interest assigned to it."

397 Judgment of 23 October 1997 in Case 159/94, Commission of the European Communities v French Republic, Para. 89.

398 Judgment of 18 June 1998 in Case C-266/96, Corsica Ferries France SA v Gruppo Antichi Ormeggiatori del porto di Genova Coop. Arl. , Para. 45.
} 
pension scheme at issue fulfils an essential social function within the Netherlands pensions system by reason of the limited amount of the statutory pension, which is calculated on the basis of the minimum statutory wage. ${ }^{399}$ To this may also be added that in Sydhavnens Sten \& Grus it seems to play a role for the outcome of the case that the interest in the environment is involved. ${ }^{400}$ Finally, it could be that the interest in the public health could have had a role to play in Ambulanz Glöckner, as the involved obligation consists in providing a permanent standby service of transporting sick or injured persons in emergencies. ${ }^{401}$

In this context, it is of interest to mention that the ECJ in Chemische Afvalstoffen actually concludes that rules such as the contested long term plan is in conflict with Articles 106 and 102 FEU (ex Articles 86 and 82 EC) when these provisions "without any objective justification" and without being necessary for the performance of a task in the general interest, those rules have the effect of favouring the national undertaking and increasing its dominant position. ${ }^{402}$ The formulation may - also in light of what was stated above - be viewed as an expression of the ECJ finding that the interpretation of Article 106(2) FEU (ex Article 86(2) EC) should be transformed into a test more identical to the one prevailing in the 'internal market law universe', so that a wide amount of considerations can be invoked by Member States. Buendia Sierra seems to be convinced that "other interests" in the broad sense have an importance within the framework of Article 106(2) FEU (ex Article 86(2) EC), as he has stated:

"Today it is obvious that many restrictions concerning public or privileged undertakings (and therefore falling within Article 86(1) [now Article 106(2) FEU]) may be justified for non-economic reasons, such as the protection of public health (this may be the case of alcohol monopolies) or the promotion of culture (television monopolies). The Court of Justice has made clear that these restrictions can also in some cases benefit from the exception in Article 86(2) [now Article 106(2) FEU].” 403

In addition, it may be mentioned that Ross - taking his point of departure in Para. 43 of The Dutch Electricity Monopoly Case - infers the following:

"This test appears to be a long way from the earlier case law. Instead of using the economic viability of the undertaking as the very essence of whether tasks were obstructed by complying with the Treaty, the revised view appears to concentrate on the justifications for protecting the service. Put another way, the crucial methodological switch is from economic measurement to value judgment in the application of the derogation. If this analysis is correct, a number of key repercussions ensue. Most immediately, such an approach would be strongly reminiscent of, and consistent with, the development of a rule of reason elsewhere in the Treaty. As seen most clearly in the free

\footnotetext{
399 Judgment of 21 September 1999 in Case C-67/96, Albany International BV v Stichting Bedrijfspensioenfonds Textielindustrie, Para. 105.

${ }^{400}$ See for the same perception, Sybe de Vries: Tensions within the Internal Market. The Functioning of the Internal Market and the Development of Horizontal and Flanking Policies, Europa Law Publishing, 2006, p. 163. Also, the Commission accepts that considerations such as environmental protection could be admissible as legitimate grounds; see Commission: Services of general interest in Europe, (96/C281/03), Para. 25.

${ }^{401}$ Judment of 25 October 1991 in Case C-475/99, Firma Ambulanz Glöckner v Landkreis Südwestpfalz, Para. 55. See for the same perception, Sybe de Vries: Tensions within the Internal Market. The Functioning of the Internal Market and the Development of Horizontal and Flanking Policies, Europa Law Publishing, 2006, p. 168.

402 Judgment of 15 June 1998 in Case C-203/96, Chemische Afvalstoffen Dusseldorp BV v Minister van Volkshuisvesting, Ruimtelijke Ordening en Milieubeheer, Para. 68.

${ }^{403}$ José Luis Buendia Sierra: Article 86 - Exclusive Rights and Other Anti-Competitive State Measures, in J. Faull \& A. Nikpay (eds.): The EC Law of Competition, Oxford University Press, 2007, p. 321.
} 
movement cases stretching back to Cassis de Dijon, [Footnote omitted] the overt disapplication of normal rules in favour of higher interests recognised in Community law has been a cornerstone in balancing Community and national regulation of markets.[Footnote omitted]... However, as the fluctuating history of the development of the free movement rules illustrates, a rule of reason is itself hardly free from controversy in its application. Indeed, what might appear to demand a less technical and more judgmental form of analysis may actually end up still firmly rooted in market appraisal.” 404

Finally, reference may be made to de Vries, who finds that the term SGEIs appears to include "horizontal and flanking policy interests". ${ }^{405}$ The author stresses that Article 106(2) FEU (ex Article 86(2) EC) seems to have a broader scope than the exemptions to the rules on free movement, which are basically of a purely non-economic nature. ${ }^{406}$ Also, the author seems to find that considerations such as the environmental protection, public health, and culture may be invoked within the context of Article 106(2) FEU (ex Article 86(2) EC). ${ }^{407}$

Altogether, it seems appropriate to assume that there are certain indications of a tendency implying that justifications in the direction of those acknowledged pursuant to the Cassis de Dijon doctrine may grow in importance within the context of Article 106(2) FEU (ex Article 86(2) EC). However, this is not the same as saying that an individual possibility of exemption as the Cassis de Dijon doctrine itself - which may be applied independently of the Treaty-based rules of exemptions e.g. in Article 36 FEU (ex Article 30 EC) - is in force, but rather that such justifications might be possible to invoke due to a somehow progressive interpretation of Article 106(2) FEU (ex Article 86(2) EC). Hereby, a movement towards a certain degree of convergence in the pattern of argumentation by the ECJ regarding the possibility of exemption between, on the one hand, free movement rules, and on the other hand, the herein analysed part of the competition rules is appearing, but that this - if taking place at all - is still only at a very introductory and uncertain stage. $^{408}$

\subsection{Preliminary Conclusions}

The above analysis clearly points in the direction of EU law in this area putting constraints on Danish law as to core welfare services. It has been explained to which degree this is so, and several observations will be stated generally about the trend in the following.

Regarding the Treaty amendments over the years, it may at first be noticed that more and more provisions have been established regarding SGEIs, hereby strengthening the European constitutional dimension of SGEIs. Second, the provisions of interest are no longer only situated in

\footnotetext{
${ }^{404}$ Malcolm Ross: Article 16 E.C. and services of general interest: from derogation to obligation?, European Law Review, 2000, pp. 25-26. Furthermore, it may be mentioned that Ekaterina Rousseva: The Concept of 'Objective Justification' of an Abuse of a Dominant Position: Can it help to Modernise the Analysis under Article 82 EC?, The Competition Law Review, 2006, p. 35, finds that: “... public policy concerns in fact serve as a justification for abuses under Article 86(2) which provides a derogation from the provisions of the Treaty, including the competition rules. However, this exemption only applies to the extent necessary to enable an undertaking entrusted with the provision of services of general economic interest (SGEI) to provide the service. The justification is the need to perform SGEI in the interest of the public. Although the text of the provision refers to services of 'economic interest', the objective contemplated in the provision is of a non-economic nature and is comparable to that of other interests enumerated in Article 30 or in the open list of mandatory requirements recognized by the Court.”

${ }^{405}$ Sybe de Vries: Tensions within the Internal Market. The Functioning of the Internal Market and the Development of Horizontal and Flanking Policies, Europa Law Publishing, 2006, pp. 160 and 379.

${ }^{406}$ Ibid., pp. 160 and 163.

${ }^{407}$ Ibid., especially pp. 165-171.

${ }^{408}$ Concerning the tendency towards an increased degree of convergence among the individual free movement rules, see Ulla Neergaard \& Ruth Nielsen: EU Ret, Thomson, 2009, Chapter 6.
} 
the context of competition law; by now they are placed in quite different contexts, thereby indicating a different impact compared with the original point of departure. Third, yet another trend to mention concerns the changed legal basis which has occurred with the Lisbon Treaty entering into force. Article 14 FEU includes an improved legal basis which is of interest in this context, as it emphasises the remarkable change in place given to the regulation of SGEIs, and it may give more room for both economic and social integration through harmonisation as such. More generally, some of the changes which have taken place could most likely be said to be a reflection of the worries of some of the Member States as to what should happen in this area; hereby in fact trying to stop the growing interference of the EU.

Regarding the development of Commission initiatives, first it may be observed that the analysis of the development brings an impression of an area which has given rise to much more general political attention in recent years. Second, the process regarding the adoption of the Services Directive demonstrated a severe reluctance of several Member States to accept that SGEIs were to be included in the scope as well as those services which may be classified as social services of general interest as well as health services. In other words, several Member States seem to be worried about the influence of the ever-growing EU law on the organisation of their welfare states. Altogether, at this more concrete level, the tensions regarding an involvement of the EU in this area appear rather significant.

Regarding the development of the case law, it may among others be observed that the "market" element seems to weight heavier than the "social" element. In other words, there has to be a good reason for setting aside competition and what that could be is still not clearly defined. Article 106 FEU (ex Article 86 EC) may be understood in the light of having been formulated in that early day period where the focus was primarily about economic integration and when the social dimension was generally viewed as left to Member States to organise.

As for the issue of whether EU law ensures the provision of core welfare services, this seems to be the case, however, so far only to a rather modest degree. For instance, several new aspects are being taken into consideration through the Treaty amendments, including e.g. an emphasis on a high level of quality, safety and affordability, equal treatment, and the promotion of universal access and of user rights. Also to be mentioned in this regard, ever since the Treaty of Amsterdam, it has been recognised that SGEIs in themselves take a place in the "shared values of the Union" and they have a role to play in "promoting social and territorial cohesion". In addition thereto, it was emphasised with the abovementioned Declaration 13 that the principles of equality of treatment, quality and continuity of public services are of central importance. These principles seem more or less upheld in the Treaty of Lisbon, in particular in the abovementioned protocol. Furthermore, a trend absolutely also worth mentioning is the "right dimension". Thus, it is of central interest that SGEIs have a place in the Charter itself. Hereby, it has become rather evident that constitutional rights of some kind have arisen in this area; rights which have traditionally been left for the Member States to decide whether should be enforced or not, and if that being the case to ensure the control of. 


\section{Conclusion}

\subsection{General Remarks}

The contributions in the articles in the books from the Blurring Boundaries project draw heavily on experiences gained before and in other contexts than the Blurring Boundaries project. All the authors in the Blurring Boundaries project have been experts in EU law for years before the beginning of the Blurring Boundaries project in 2007 and have published widely on this subject in other contexts. Many of the articles are therefore re-statements and re-readings of the development of the acquis communautaire on the interplay between, on the one side, national and EU welfare law and, on the other side, EU law on free movement and fundamental rights, in particular primary EU law on these subjects, but also a few directives, notably the Services Directive. As set out in section 1, the authors of the articles have given preference to studying primary EU law (which we see as constitutional law) on the interplay between welfare law and EU law on free movement and fundamental rights and non-discrimination rather than secondary law on selected aspects of welfare law, for example in health law or labour law.

As appears from section 1, most of the authors of the articles in the three books from the Blurring Boundaries project are non-Danish scholars. The authors of this paper (Ulla Neergaard and Ruth Nielsen) and the PhD (Grith Ølykke) ${ }^{409}$ are the only Danish participants in the Blurring Boundaries project. In the present paper we focus more than we have done generally in the Blurring Boundaries project on the (specific) consequences for Danish welfare law and the Danish welfare state of the EU development in order to formulate the answers to the specific research questions underlying the Blurring Boundaries project - i.e. to what extent the EU puts constraints on Danish welfare law and the Danish welfare state (research question 1) and whether EU law ensures welfare rights and services in a broad sense (research question 2); see for a more detailed description and explanation of the research questions above in section one - in a more precise form than what appears from the three (first) books from the Blurring Boundaries conferences.

The Blurring Boundaries project has contributed with clarifications, both at a conceptual and dogmatic level, of the European Social Model. In the Blurring Boundaries project, three aspects of this model have been particularly highlighted:

- the constitutionalisation of the European Social Model,

- its multi-level legal character, and

- the clash between market access justice at EU level and distributive justice at national level.

All the contributors to the Blurring Boundaries project have looked at the various aspects of the interface between EU law and national welfare law in an evolutionary perspective. At a general level the research undertaken in the Blurring Boundaries project has confirmed that there is an increasingly blurred boundary between public and private law, for example with regard to services

\footnotetext{
${ }^{409}$ Grith Ølykke, who worked as PhD student on the project from 1 April 2007-31 March 2010, acquired her PhD degree on 22 April 2010 on the basis of the thesis Grith Ølykke: Low Tenders - With an Emphasis on Public Tenderers, Copenhagen (DJØF Publishing) 2010.
} 
of general interest, and between EU law and national law. In a summary form the main answers to the two main research questions resulting from the Blurring Boundaries project are the following:

\subsection{Research Question 1: Does EU Law Put Constraints upon Danish Law on Core Welfare Services, and If Yes, How, to What Extent and What Is the Trend in the Development?}

This question is about the extent to which the Danish national state still has competence to decide how it will organise welfare in a broad sense, e.g. social benefits, worker protection, consumer protection, health care, etc. in Denmark and at what level it will provide welfare services. Possible EU law constraints can come from primary law, notably the Treaty provisions on free movement or fundamental rights and non-discrimination and ECJ case law on these issues, and from secondary law, primarily in the form of directives, e.g. the Services Directive or the discrimination directives.

It is clear from the case law of the ECJ that welfare law-related discriminations and/or restrictions are not outside the scope of application of EU free movement law. That also applies when the welfare aspects at issue can be regarded as fundamental rights. Welfare rights must be balanced against the right to free movement. One of the most remarkable developments in the EU single market law has been the expansive interpretation given to the free movement provisions by the ECJ. The case law has shifted the institutional balance in the EU in the field of liberalisation of services.

National restrictions/discriminations on the provision of welfare services may be justified in accordance with the case law of the ECJ by reference to two different groups of legitimate aims: either the Treaty-based exceptions from the free movement provisions, in particular public policy, public security or public health, or by reference to all the overriding reasons relating to the public interest that are accepted in the case law of the ECJ. In addition to a legitimate aim, restrictions/discriminations must meet the requirements of the principle of proportionality, i.e. be appropriate and necessary in order to be justified. In practice, the ECJ has been prepared to accept most 'imperative reasons' advanced by Member States, but it has analysed very carefully whether the conditions of appropriateness and necessity are fulfilled. In particular, the ECJ examines whether the same aim could be achieved by less restrictive means, such as through reliance on the requirements of the home state. The free movement provisions, in particular the way the ECJ interprets the proportionality principle, reduces the freedom of the Member States to arrange their welfare as they wish, in particular in the area of consumer law.

In our view, the rules on migrant workers covered by Article 45 FEU do not tip the balance between free movement and fundamental rights to the detriment of fundamental rights. It may, however, be different in respect of workers posted by employers exercising their right of freedom to provide services under Article 56 FEU. Article 45 FEU does not apply to such workers.

The 'collision' between EU free movement law and the right to take collective actions under national labour law, not least the judgment in the Laval case, has given rise to vivid debate and concern in the Scandinavian countries. The ECJ tends to interpret EU internal market law in a way that sees limitation of market access as discrimination or unlawful restriction. Seen from a Nordic perspective, the single most controversial ECJ judgment in the social field is Laval, which illustrates the clash between a European Social Model based on access justice at EU level and national welfare states with highly developed distributive justice systems at national level, in the 
Laval case that part of the national distributive justice system that deals with minimum wages. The ECJ's judgment in Laval is open to different interpretations. In Denmark, the main social partners, the government and the parliamentary legislator have chosen to interpret the ECJ judgment as only requiring transparency in the way access to the Danish labour market is hindered but not as preventing Denmark from upholding its way of fixing minimum wages.

The Member States' possibilities for justifying a restriction on free movement is more limited if the restriction both limits the right to free movement and a fundamental right. In Festersen, the ECJ stated that if a restriction (in that case a residence requirement which restricted the free movement of capital) at the same time adversely affects the enjoyment of a fundamental right, the restriction is to be considered particularly restrictive. Since the Charter - as of 1 December 2009 - became legally binding, it has therefore limited the discretion of the Member States to justify restrictions under the Cassis de Dijon case law of the ECJ.

Minimum harmonisation takes away the freedom of a Member State to set a lower level than the EU minimum level. For Denmark that has had practical importance in regard to non-discrimination law. Full harmonisation detracts more competences from the Member States by also setting a ceiling over welfare services. In many welfare relevant areas, the EU only has competence to minimum harmonisation. In consumer law and in regard to services of general economic interest, the EU has, however, competence to full harmonisation.

Neergaard concludes her analysis ${ }^{410}$ of the concept of solidarity in EU law by stating that 'solidarity' in EU law is important. It is right in the heart of the many tensions at present between EU law and national welfare states. It is a concept which has an enormous potential as an explanatory factor and as a general legal principle in horizontal terms. It will also play an increasing role as a value and an identity as well as in relation to fundamental rights.

The multi-level constitution of the European Social Model puts constraints on the Danish legislator (i.e. the national Parliament (Folketing) and in regard to the labour market the social partners' competence to regulate the labour market by collective agreement) in that it deprives them of their prior role as highest authority and source of legitimacy and subjects it/them to control by the ECJ. Denmark began its membership of the EU with a very low level of anti-discrimination protection and has had to raise this level in order to comply with the minimum standards set by EU law.

EU law on free movement limits the options of Member States to arrange their tax law as they wish. Direct taxation is still under Member States' competence, but they must respect EU primary law on free movement on the internal market when they exercise their legislative competence in tax law. There have been a number of cases before the ECJ about national tax law as a possible restriction to free movement. EU law also makes a welfare state more costly. Rights either have to be given to everyone irrespective of nationality or to no one. That provides a political argument for dismantling part of the welfare state, i.e. to choose to give welfare rights to no one or more limited rights to everyone to avoid the cost of having to extend the rights to EU migrants and possibly also

\footnotetext{
${ }^{410}$ Ulla Neergaard: In Search of the Role of 'Solidarity' in Primary Law and the Case Law of the European Court of Justice in Ulla Neergaard, Ruth Nielsen and Lynn Roseberry (eds.): The Role of Courts in Developing a European Social Model - Theoretical and Methodological Perspectives, Copenhagen 2010.
} 
third-country nationals. Denmark has used the Eastern enlargement and the resulting expansion of the numbers of EU migrants with mobility rights as a reason for tightening Danish welfare law.

Regarding the development of the case law on services of general economic interest, it may be observed that the 'market' element seems to weight heavier than the 'social' element. In other words, there has to be a good reason for setting aside competition and what that exactly could be is still not clearly defined. Article 106 FEU (ex Article 86 EC) may be understood in the light of having been formulated in that early period where the focus primarily was about economic integration and when the social dimension was in the whole and large viewed as left to Member States to organise.

\subsection{Research Question 2: Is EU Law Ensuring the Provision of Core Welfare Services, and If Yes, How, to What Extent and What Is the Trend in the Development?}

EU law is ensuring the provision of core welfare services in a wide sense in particular in the following ways:

- EU law has improved the rights of EU economic actors and EU migrants when exercising the rights to free movement of goods, services, capital, freedom of establishment and persons,

- EU law ensures fundamental social rights, and

- EU law has a strong non-discrimination agenda which has had a deep impact on national law, not least Danish law, which was at a comparatively low level of anti-discrimination protection when Denmark entered the EC/EU 1 January 1973.

At EU level EU law guarantees fundamental rights at a level that is at least as high as the German standard of fundamental rights (Grundrechte) and accords all EU citizens directly applicable fundamental rights with supremacy over their national law. In particular in gender equality cases EU law has successfully been invoked against Danish law in a number of cases.

The fundamental rights and anti-discrimination rights developed by the EU strengthen the welfare rights of persons living in the EU. The right to equal treatment regardless of certain specified characteristics (e.g. sex, race, ethnic origin) is a general principle of EU law and a fundamental right. Since non-discrimination is a fundamental right, all Member States must respect the principle of non-discrimination when acting to enforce or implement EU rules. Furthermore, when a Member State justifies national rules that hinder the exercise of free movement rights, it must not only show that the national rules fall within the Treaty exceptions (public policy, public security and public health) or overriding reasons of public interest but also that the national rules are consistent with fundamental rights, including the principle of non-discrimination.

As for the issue of whether EU law ensures the provision of core welfare services, this seems to be the case in regard to services of general economic interest, however, so far only to a rather initial degree. For instance, several new aspects are being taken into consideration through the Treaty amendments, including e.g. an emphasis on a high level of quality, safety and affordability, equal treatment, and the promotion of universal access and of user rights. Also to be mentioned in this regard, ever since the Treaty of Amsterdam, it has been recognised that SGEIs in themselves take a place in the "shared values of the Union" and they have a role to play in "promoting social and territorial cohesion". In addition thereto, it was emphasised with the abovementioned Declaration 
13 that the principles of equality of treatment, quality and continuity of public services are of central importance. These principles seem more or less upheld in the Treaty of Lisbon, in particular in the abovementioned protocol. Furthermore, a trend absolutely also worth mentioning is the 'right dimension'. Thus, it is of central interest that SGEIs have a place in the Charter itself. Hereby, it has become rather evident that constitutional rights of some kind have arisen in this area; rights which have traditionally been left for the Member States to decide whether should be enforced or not, and if that being the case to ensure the control of.

\subsection{Further Developments}

The Blurring Boundaries project has dealt with some issues where important further development has taken place after the publication of the books from the project. An important and recurring theme in the Blurring Boundaries project has been the Lisbon Treaty. The second book from the Blurring Boundaries project ${ }^{411}$ was based on a conference under the theme: The Lisbon Treaty - a Step Towards Integrating Welfare Functions into EU Law? The third Blurring Boundaries conference was held in September 2009. The deadline for articles for the third book from the conference, which was published in early March 2010, ${ }^{412}$ was 15 October 2009, i.e. six weeks before the Lisbon Treaty finally entered into force 1 December 2009. It was of course possible to analyse the consequences of the Lisbon Treaty before its entering into force, but the fact that the Lisbon Treaty is now law in force changes the institutional and constitutional context of many of the legal problems dealt with in the Blurring Boundaries articles.

Another recurring theme in the Blurring Boundaries project has been the Laval case; see on this case above, in particular in section 6.3. On 2 December 2009, the Swedish Labour Court handed down its judgment, which is based on a controversial interpretation of EU law on damages which is likely to give rise to further debate and has already resulted in an application to the Swedish Supreme Court for nullification of the Labour Court's judgment and re-opening of the case; see above in section 6.3 .

The work with the Blurring Boundaries project uncovered a need for further clarification of the theoretical and methodological basis of EU legal scholarship. The research group behind the Blurring Boundaries project has therefore applied for and obtained a grant from the Danish Social Science Research Council for a new project on European Legal Method (see www.cbs.dk/elm) to be carried out from 2010-2012. The European Legal Method project examines the extent to which it is possible to identify a coherent legal method (doctrine of the sources of law and their interpretation) that may be applied when analysing EU law and the law of EU Member States within the scope of application of EU law. As part of the project, research conferences will be arranged. The first will take place 19 November 2010 with the theme European Legal Method; see for details and programme www.cbs.dk/elm1.

\footnotetext{
${ }^{411}$ Ulla Neergaard, Ruth Nielsen and Lynn Roseberry (eds.): Integrating Welfare Functions into EU Law - From Rome to Lisbon, Copenhagen 2009.

412 Ulla Neergaard, Ruth Nielsen and Lynn Roseberry (eds.): The Role of Courts in Developing a European Social Model Theoretical and Methodological Perspectives, Copenhagen 2010.
} 


\section{Annex 1. Publications from the Blurring Boundaries project}

The four main publications until now (May 2010) from the Blurring Boundaries project are:

1) Ulla Neergaard, Ruth Nielsen and Lynn Roseberry (eds.): The Services Directive Consequences for the Welfare State and the European Social Model", Copenhagen 2008,

2) Ulla Neergaard, Ruth Nielsen and Lynn Roseberry (eds.): Integrating Welfare Functions into EU Law - From Rome to Lisbon, Copenhagen 2009,

3) Ulla Neergaard, Ruth Nielsen and Lynn Roseberry (eds.): The Role of Courts in Developing a European Social Model - Theoretical and Methodological Perspectives, Copenhagen 2010,

4) Grith Ølykke: Low Tenders - With an Emphasis on Public Tenderers, phd-afhandling, Copenhagen 2010.

Ulla Neergaard, Ruth Nielsen and Lynn Roseberry (eds.): The Services Directive - Consequences for the Welfare State and the European Social Model", Copenhagen 2008 includes the following articles:

1) Ulla, Neergaard Ruth Nielsen and Lynn Roseberry: Introduction: The Services Directive in a Legal perspective

2) Dagmar Schiek: The European Social Model and the Services Directive

3) Ulla Neergaard: Services of general (economic) interest and the Services Directive

4) Lynn Roseberry: The general principle of non-discrimination and the Services Directive

5) Elisabetta Bergamini: Freedom of Establishment under the Services Directive

6) Jukka Snell: Freedom to provide Services under the Services Directive compared to the existing case law of the ECJ

7) Ruth Nielsen: Rights of Recipients of Services, in particular Article 20 in the Services Directive

8) Frank Hendrickx: The Services Directive and Social Dumping

Ulla Neergaard, Ruth Nielsen and Lynn Roseberry (eds.): Integrating Welfare Functions into EU Law - From Rome to Lisbon, Copenhagen 2009 includes the following articles:

1) Ulla Neergaard, Ruth Nielsen and Lynn Roseberry: Introduction

Part I: New Aims and Values of the EU?

2) Christian Joerges: A Renaissance of the European Economic Constitution?

3) Dragana Damjanovic and Bruno de Witte: Welfare Integration through EU Law: The Overall Picture in the Light of the Lisbon Treaty

Part II: Union Citizens and Migrant Workers

4) Ruth Nielsen: The Charter of Fundamental Rights and Migrant Workers' Welfare Rights

5) Andrzej Swiatkowski: European Union Citizenship and Rights of Access to Welfare Services as Compared to Welfare Rights Guaranteed by the Council of Europe as Seen from the Perspective of a New Member State

6) Michael Dougan: The Spatial Restructuring of National Welfare States within the European Union: the Contribution of Union Citizenship and the Relevance of the Treaty of Lisbon

Part III: Liberalisation of Public Welfare Services

7) Ulla Neergaard: Services of General (Economic) Interest: What Aims and Values Count?

8) Vassilis Hatzopoulos: Services of general interest in healthcare: an exercise in deconstruction?

9) Grith Skovgaard Ølykke: Submission of Low Price Tenders by Public Tenderers - Exemplified by public procurement of railway services in Denmark

10) Erika Szyszczak: Legal Tools in the Liberalisation of Welfare Markets

Part IV: The Relationship between Prohibitions against Discrimination and Integration of Welfare Functions into EU law

11) Lynn Roseberry: The Integration of Welfare Functions into EU Law through the Principle of Nondiscrimination and the Consequences for Third Country Nationals

12) Aileen McColgan: Prohibitions against Discrimination and Integration of Welfare Functions into EU law: Potential Pitfalls? 
Ulla Neergaard, Ruth Nielsen and Lynn Roseberry (eds.): The Role of Courts in Developing a European Social Model - Theoretical and Methodological Perspectives, Copenhagen 2010 includes the following articles:

1) Ulla Neergaard, Ruth Nielsen and Lynn Roseberry: Introduction

Part I. Horizontal Approach

2) Hans-W. Micklitz: Judicial Activism of the European Court of Justice and the Development of the European Social Model in Anti-Discrimination and Consumer Law

3) Dagmar Schiek: Is There a Social Ideal of the European Court of Justice?

4) Ulla Neergaard: In Search of the Role of 'Solidarity' in Primary Law and the Case Law of the European Court of Justice

Part II. subject-oriented Approach

5) Eleanor Spaventa: The Constitutional Impact of Union Citizenship

6) Mia Rönnmar: Labour Law in the Courts. The Role of European Case Law on Fundamental Trade Union Rights in an Evolving EU Industrial Relations System

7) Lynn Roseberry: International Human Rights Treaties and Fundamental Rights in the Case Law of the European Court of Justice: Pointing towards a European Social Model?

Part III. Theoretical and methodological Aspects

8) Ruth Nielsen: Scandinavian Legal Realism and EU Law

9) Finn Arnesen: The Case Law of the European Courts as Seen from a National Supreme Court - the Case of Norway

10) Joxerramon Bengoetxea: Legal Reasoning and the Hermeneutic Turn in the Law - Remarks on the European Court of Justice

11) Antonina Bakardjieva Engelbrekt: Institutional Theories, EU Law and the Role of the Courts for developing a European Social Model

In addition members of the Blurring Boundaries research group have either individually or together with other collaborators published a number of works related to the theme of the Blurring Boundaries project, namely the following:

\section{Ulla Neergaard:}

- “'Services of General Economic Interest' and Related Concepts: The Nature of the Beast”, in 'The Changing Legal Framework of Services of General Interest in Europe - Between Competition and Solidarity', T. M. C. Asser Press, Holland, in collaboration with Cambridge University Press, England, 2009, edited by Ulla Neergaard, Markus Krajewski \& Johan van de Gronden, pp. 17-50.

- “Introduction”, written together with Markus Krajewski \& Johan van de Gronden, in “The Changing Legal Framework of Services of General Interest in Europe - Between Competition and Solidarity”, T. M. C. Asser Press, Holland, in collaboration with Cambridge University Press, England, 2009, ed. by Ulla Neergaard, Markus Krajewski \& Johan van de Gronden, pp. 1-13.

- "The Changing Legal Framework of Services of General Interest in Europe - Between Competition and Solidarity”, T. M. C. Asser Press, Holland, in collaboration with Cambridge University Press, England, 2009, ed. by Ulla Neergaard, Markus Krajewski \& Johan van de Gronden (approximately 50 pages).

- "Privilegerede virksomheder", Chapter. 10 in "Konkurrenceretten i EU”, Djoef Publishing, Denmark, 2009, 3. ed., with Caroline Heide-Jørgensen, Simon Evers Hjelmborg, Jan Magne 
Langseth, Sune Troels Poulsen, Charlotte Friis Bach Ryhl, Jens Schovsbo \& Peter Stig Jacobsen.

- "Tobias Indén, Kommunen som konkurrent. Kommunalrättsliga befogenheter och konkurrensrättsliga begränsningar, ak. avh., Iustus förlag, 2008, 416 s.”, Juridisk Tidsskrift, Sweden, 2009, s. 938-944.

- “Koncessioner \& konkurrence - et EU-retligt perspektiv”, Tidsskrift for Rettsvitenskap, Norway, 2008, nr. 1, pp. 1-34.

- "Public service concessions and related concepts - the increased pressure from Community law on Member States' use of concessions”, Public Procurement Law Review, England, 2007, 6, pp. 387-409.

- "Modernising Article 82 EC - with Particular Focus on Public and Otherwise Privileged Undertakings”, Europarättsligt Tidsskrift, Sweden, No. 1, 2007, pp. 54-82.

Ruth Nielsen:

- “Free Movement and Fundamental Rights”, European Labour Law Journal 2010 p. 19.

- "Civilretlige diskriminationsforbud” (book in Danish), Copenhagen 2010.

- Together with Agnete Andersen og Kirsten Precht: "Ligestillingslovene med kommentarer" (book). Volume 1: Forskelsbehandlingsloven, den etniske ligebehandlingslov, ligestillingsloven, loven om ligebehandlingsnævnet, håndhævelse og generelle spørgsmål, Copenhagen 2008.

Volume 2: Ligebehandlingsloven, ligelønsloven, lov om ret til orlov ved barsel m.v., barseludligningsloven og loven om forsikring, pension og lignende finansielle ydelser, (commentary to Danish equality legislation) Copenhagen 2010.

- ”Delt bevisbyrde i ligestillingssager”, Juristen 2010 nr. 1.

- ”Den retlige regulering af handicapdiskrimination” in Vänbok till Ronnie Eklund, Uppsala 2010.

- "Diskriminationsforbud og kontraktret”, JFT (Tidskrift udgivan av Juridiska Foereningen i Finland) 2009 s. 826.

- ”Aldersdiskrimination: EU-retlig og dansk praksis”, EU-Ret \& Menneskeret 2009 s. 281.

- "LO's juridiske råderum vedrørende løngabet: Udredning af kollektive overenskomsters og det fagretlige systems bæredygtighed i forhold til ligeløn og lukning af løngabet” Copenhagen 2009, at LO's website www.loli.dk.

- "The Laval and Viking Cases: Freedom of Services and Establishment v. Industrial Conflict in the European Economic Area and Russia”, Bulletin of Comparative Labour Relations p. 25.

- ”Aldersdiskrimination i arbejdsretten og kontraktretten”, Festskrift til Hennning Jakhellns 70årsdag.

- "Is EU Equality law capable of addressing multiple and intersectional discrimination yet? Precautions against neglecting intersectional cases”, in Dagmar Schiek and Victoria Schrege (eds): European Union Discrimination Law: Comparative Aspects on Multidimensional Equality Law, London, 2008. 
- "Arbejdsret og flexicurity: Grønbogen om modernisering af arbejdsretten”, in Arbeidsrett. 2007; vol. 4, nr. 3, s. 155.

- With Sandfeld Jakobsen, Søren: ”Dansk spillelovgivning og EU-retten”, UfR 2008 B s. 1.

- "EU-domstolens afgørelser om konfliktret i Viking- og Laval-sagerne”, Arbejdsretligt Tidsskrift 2008.

- "Udstationering af arbejdstagere som led i udveksling af tjenesteydelser: Viking-, Laval- og Rüffert-sagerne”, Arbeidsrett, 2008 s. 61.

- "Status and protection of migrant workers: General report for IX European Congress of Labour and Social Security Law”, 2008. s. 1-54, Conference: 9th European Congress of Labour and Social Security Law, nr. 9, Freiburg, Germany, at http://kongress-undkommunikation.com/cms/website.php?id=/en/labourlaw2008/start/submissions/topic2.htm

- "EU Public Procurement Law and Nordic Labour Law - Recent Developments and Future Challenges”, in Scandinavian Studies in Law Volume 50, What is Scandinavian Law?, Stockholm 2007.

- ”Standstill og ugyldighed/uvirksomhed af offentlige kontrakter”, U 2007, B s.120.

• With Andersen, Agnete: ”Mainstreaming i juridisk perspektiv” (book), Copenhagen 2007.

Lynn Roseberry:

- "The Assimilationist Anti-discrimination Paradigm and the Immigrant Woman: Suggestions on How to Re-Conceptualise Discrimination Claims," to be published by an international publisher in an anthology edited by Professor Dagmar Schieck, Leeds University, in 2010. Total number of pages contributed: approximately 25.

- "Religion, Ethnicity and Gender in the Danish Headscarf Debate", in Dagmar Schieck and Victoria Chege (eds.), European Union Discrimination Law: Comparative Perspectives on Multidimensional Equality Law (London: Routledge, Cavendish 2008) pages 329-350. 